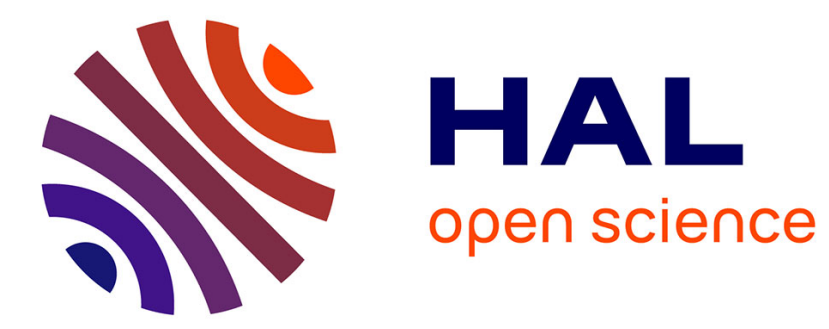

\title{
Greenhouse gas fluxes over managed grasslands in Central Europe
}

\author{
Lukas Hörtnagl, M Barthel, N Buchmann, W Eugster, K Butterbach-Bahl, \\ Eugenio Díaz-Pinés, M. Zeeman, Katja Klumpp, Ralf Kiese, M Bahn, et al.
}

\section{- To cite this version:}

Lukas Hörtnagl, M Barthel, N Buchmann, W Eugster, K Butterbach-Bahl, et al.. Greenhouse gas fluxes over managed grasslands in Central Europe. Global Change Biology, 2018, 24 (5), 10.1111/gcb.14079 . hal-01714760

\author{
HAL Id: hal-01714760 \\ https://hal.science/hal-01714760
}

Submitted on 21 Feb 2018

HAL is a multi-disciplinary open access archive for the deposit and dissemination of scientific research documents, whether they are published or not. The documents may come from teaching and research institutions in France or abroad, or from public or private research centers.
L'archive ouverte pluridisciplinaire $\mathbf{H A L}$, est destinée au dépôt et à la diffusion de documents scientifiques de niveau recherche, publiés ou non, émanant des établissements d'enseignement et de recherche français ou étrangers, des laboratoires publics ou privés.

\section{(ㅇ)(1) $\$$}

Distributed under a Creative Commons Attribution - NonCommerciall 4.0 International 
DR. LUKAS HÖRTNAGL (Orcid ID : 0000-0002-5569-0761)

DR. RALF KIESE (Orcid ID : 0000-0002-2814-4888)

Article type : Primary Research Articles

\section{Title page}

\section{Greenhouse gas fluxes over managed grasslands in Central Europe}

running head: GHG fluxes over managed European grasslands

Hörtnagl L. (1), Barthel M. (1), Buchmann N. (1), Eugster W. (1), Butterbach-Bahl K. (2), DíazPinés E. (2,3), Zeeman M. (2), Klumpp K. (4), Kiese R. (2), Bahn M. (5), Hammerle A. (5), Lu H. (2), Ladreiter-Knauss T. (5), Burri S.(1) and Merbold L. (1,6)

(1) ETH Zürich, Institute of Agricultural Sciences, Zürich, Switzerland, (2) Karlsruhe Institute of Technology (KIT), Institute of Meteorology and Climate Research, Karlsruhe, Germany, (3) University of Natural Resources and Life Sciences (BOKU), Institute of Soil Research, Vienna, Austria, (4) INRA, Grassland Ecosystem Research, Clermont-Ferrand, France, (5) University of Innsbruck, Institute of Ecology, Innsbruck, Austria, (6) Mazingira Centre, International Livestock Research Institute (ILRI), Nairobi, Kenya

This article has been accepted for publication and undergone full peer review but has not been through the copyediting, typesetting, pagination and proofreading process, which may lead to differences between this version and the Version of Record. Please cite this article as doi: $10.1111 / \mathrm{gcb} .14079$

This article is protected by copyright. All rights reserved. 
Corresponding author: Lukas Hörtnagl, email: lukas.hoertnagl@usys.ethz.ch, phone: +41 44632 5871

Keywords: nitrous oxide, methane, eddy covariance, chamber, fertilizer, emission factor, carbon dioxide, grazing, management, livestock

Type of paper: Primary Research Article

\section{Abstract}

Central European grasslands are characterized by a wide range of different management practices in close geographical proximity. Site-specific management strategies strongly affect the biosphere-atmosphere exchange of the three greenhouse gases $(\mathrm{GHG})$ carbon dioxide $\left(\mathrm{CO}_{2}\right)$, nitrous oxide $\left(\mathrm{N}_{2} \mathrm{O}\right)$ and methane $\left(\mathrm{CH}_{4}\right)$. The evaluation of environmental impacts at site level is challenging, because most in-situ measurements focus on the quantification of $\mathrm{CO}_{2}$ exchange, while long-term $\mathrm{N}_{2} \mathrm{O}$ and $\mathrm{CH}_{4}$ flux measurements at ecosystem scale remain scarce.

Here, we synthesized ecosystem $\mathrm{CO}_{2}, \mathrm{~N}_{2} \mathrm{O}$ and $\mathrm{CH}_{4}$ fluxes from 14 managed grassland sites, quantified by eddy covariance or chamber techniques. We found that grasslands were on average a $\mathrm{CO}_{2}$ sink (-1783 to $\left.-91 \mathrm{~g} \mathrm{CO}_{2} \mathrm{~m}^{-2} \mathrm{yr}^{-1}\right)$, but a $\mathrm{N}_{2} \mathrm{O}$ source $\left(18-638 \mathrm{~g} \mathrm{CO}_{2}\right.$-eq. $\left.\mathrm{m}^{-2} \mathrm{yr}^{-1}\right)$, and either a $\mathrm{CH}_{4}$ sink or source (-9 to $488 \mathrm{~g} \mathrm{CO}_{2}$-eq. $\mathrm{m}^{-2} \mathrm{yr}^{-1}$ ). The net GHG balance (NGB) of nine sites where measurements of all three GHGs were available was found between -2761 and -58 $\mathrm{g}$ $\mathrm{CO}_{2}$-eq. $\mathrm{m}^{-2} \mathrm{yr}^{-1}$, with $\mathrm{N}_{2} \mathrm{O}$ and $\mathrm{CH}_{4}$ emissions offsetting concurrent $\mathrm{CO}_{2}$ uptake by on average $21 \pm 6 \%$ across sites. The only positive NGB was found for one site during a restoration year with ploughing. The predictive power of soil parameters for $\mathrm{N}_{2} \mathrm{O}$ and $\mathrm{CH}_{4}$ fluxes was generally low and varied considerably within years. However, after site-specific data normalization we

This article is protected by copyright. All rights reserved. 
identified environmental conditions that indicated enhanced GHG source/sink activity ('sweet spots') and gave a good prediction of normalized overall fluxes across sites. The application of animal slurry to grasslands increased $\mathrm{N}_{2} \mathrm{O}$ and $\mathrm{CH}_{4}$ emissions. The $\mathrm{N}_{2} \mathrm{O}-\mathrm{N}$ emission factor across sites was $1.8 \pm 0.5 \%$, but varied considerably at site level among the years $(0.1-8.6 \%)$. Although grassland management lead to increased $\mathrm{N}_{2} \mathrm{O}$ and $\mathrm{CH}_{4}$ emissions, the $\mathrm{CO}_{2}$ sink strength was generally the most dominant component of the annual GHG budget.

\section{Introduction}

Central European grasslands are characterized by a wide range of different management practices, ranging from intensively managed lowland pastures and meadows to rather extensively managed high alpine grasslands (Gilmanov et al., 2007; Bahn et al., 2008; Wohlfahrt et al., 2008a). Farming systems operate within their socio-economic and environmental boundaries, leading to management decisions that define type, frequency, timing and intensity of management events (Huber et al., 2013, Huber et al., 2014).

Grassland management-such as the amount and type of fertilizer applied, the frequency of cutting or the duration of grazing-strongly impacts the exchange of greenhouse gases (GHG), water and energy between the grassland ecosystem and the atmosphere and subsequently affects the biogeochemical cycling of carbon (C) and nitrogen (N) (Schulze et al., 2009). Annual GHG budgets of grasslands, consisting of the three GHGs carbon dioxide $\left(\mathrm{CO}_{2}\right)$, nitrous oxide $\left(\mathrm{N}_{2} \mathrm{O}\right)$ and methane $\left(\mathrm{CH}_{4}\right)$, are thus influenced directly by management (Lal, 2010; Gelfand et al., 2011). The atmospheric concentrations of all three trace gases are still increasing at present, with anthropogenic activities being the major driver (IPCC, 2013). Both $\mathrm{N}_{2} \mathrm{O}$ and $\mathrm{CH}_{4}$ have high warming potentials, $298\left(\mathrm{~N}_{2} \mathrm{O}\right)$ and $34\left(\mathrm{CH}_{4}\right)$ times that of a corresponding mass of $\mathrm{CO}_{2}$ emitted on a 100-year time horizon (IPCC, 2013). Agricultural grassland management activities are

This article is protected by copyright. All rights reserved. 
closely connected to emissions of both non- $\mathrm{CO}_{2}$ gases and to the uptake or emission of $\mathrm{CO}_{2}$ (Tubiello et al., 2015). Emissions of $\mathrm{N}_{2} \mathrm{O}$ and $\mathrm{CH}_{4}$ can contribute to an increase of the net GHG balance (NGB) of a grassland, offsetting concurrent $\mathrm{CO}_{2}$ sequestration in terms of $\mathrm{CO}_{2}$ equivalents (Liu \& Greaver, 2009; Schulze et al., 2009). This offset can be large and can even result in shifting a grassland from being a net GHG sink to a net source. The $\mathrm{CO}_{2}$ sink strength as well as the $\mathrm{N}_{2} \mathrm{O}$ and $\mathrm{CH}_{4}$ source strengths of grasslands have been found to vary significantly across years and sites (Soussana et al., 2007; Gilmanov et al., 2010).

$\mathrm{N}_{2} \mathrm{O}$ is produced by microbial activities in soils, mainly via nitrification and denitrification processes. $\mathrm{N}_{2} \mathrm{O}$ can also be consumed by microbial processes such as denitrification, so that the net flux of $\mathrm{N}_{2} \mathrm{O}$ observed at the soil surface is the result of simultaneously occurring production and consumption processes (Butterbach-Bahl et al., 2013). The production of soil $\mathrm{N}_{2} \mathrm{O}$ is controlled by various factors, such as soil water content, temperature, $\mathrm{pH}$ and the amount of available labile C and N (Holtan-Hartwig et al., 2002; Barnard et al., 2005; Prentice \& Ri, 2008). $\mathrm{N}_{2} \mathrm{O}$ production in soils is fueled by high $\mathrm{N}$ availability, which is mainly caused by the application of organic (solid manures or liquid slurries) and synthetic fertilizers to soils, but also due to the cultivation of legumes (Davidson, 2009; Fowler et al., 2009; Lüscher et al., 2014). For grasslands and meadows, additional $\mathrm{N}$ input might originate from livestock excreta (urine and faeces) (Galloway et al., 2003; Saggar et al., 2013; Paustian et al., 2016). Application of organic and inorganic fertilizers have been shown to result in soil $\mathrm{N}_{2} \mathrm{O}$ emission peaks, the magnitude of which depends on form, amount and timing of applied $\mathrm{N}$ as well as presence or absence of organic matter (Laville et al., 2011). Due to the high spatial and temporal variability of $\mathrm{N}_{2} \mathrm{O}$ production, estimating national and sub-national emissions remains difficult and is associated with major uncertainties (Reay et al., 2012). The importance of soils as sinks for atmospheric

This article is protected by copyright. All rights reserved. 
$\mathrm{N}_{2} \mathrm{O}$ seems to be small and not to exceed $2 \%$ of current estimated sources (Schlesinger, 2013), and it is rather unlikely that fertilized agricultural soils act as $\mathrm{N}_{2} \mathrm{O}$ sinks (Syakila \& Kroeze, 2011).

$\mathrm{CH}_{4}$ is mainly produced by single-celled archaea (methanogens) that are found in anaerobic microsites in the soil, water-saturated zones with high $\mathrm{C}$ content and the rumen of ruminants (Baldocchi et al., 2012; Hiller et al., 2014). Methanogenesis is the end point of the anaerobic breakdown of organic matter (Whalen, 2005). In Europe, the vast majority of agricultural $\mathrm{CH}_{4}$ emissions originates from enteric fermentation (77\%), but a considerable amount is also released as a consequence of manure decomposition processes (9\%) during manure management (FAOSTAT, 2017). High $\mathrm{CH}_{4}$ emissions were correspondingly reported from regions with intensive agriculture and animal husbandry (Barnosky, 2008; Schulze et al., 2009; Frankenberg et al., 2011). The major global sinks for $\mathrm{CH}_{4}$ are biological oxidation by aerobic and anaerobic methanotrophs at $\mathrm{CH}_{4}$ production sites, and photochemical oxidation by hydroxyl radicals in the atmosphere (Tate, 2015). Aerobic soils constitute an additional $\mathrm{CH}_{4}$ sink, with atmospheric $\mathrm{CH}_{4}$ diffusing into the soil and being oxidized by methanotrophic bacteria (Dunfield, 2007; Dutaur \& Verchot, 2007; Unteregelsbacher et al., 2013). In these well-aerated soils, observed net $\mathrm{CH}_{4}$ uptake is also the consequence of $\mathrm{CH}_{4}$ consumption (methanotrophy) being larger than the $\mathrm{CH}_{4}$ production (methanogenesis) in the soil (Conrad, 2009). Oxidation rates are influenced by abiotic factors such as soil moisture and soil temperature, with changes in soil moisture accounting for most of the observed variability (Price et al., 2004; Tate, 2015).

In Europe, $21 \%$ of the terrestrial surface is currently dedicated to agriculture (FAOSTAT, 2017). Most agricultural land is used for arable crops (59\%), followed by permanent meadows and pastures (38\%) and permanent crops, e.g. vines and olive trees (3\%). In 2014, European

This article is protected by copyright. All rights reserved. 
agriculture contributed $11 \%$ to global total GHG emissions from agriculture (FAOSTAT, 2017). Total European $\mathrm{N}_{2} \mathrm{O}$ emissions in terms of $\mathrm{CO}_{2}$-equivalents have exceeded $\mathrm{CH}_{4}$ emissions since 2011, with $\mathrm{N}_{2} \mathrm{O}$ contributing 52\% $\left(\mathrm{CH}_{4}: 48 \%\right)$ to total European GHG emissions in 2014 (FAOSTAT, 2017). Although $\mathrm{CH}_{4}$ emissions from enteric fermentation constitute the largest single source of GHGs from agriculture in Europe (2014: 38\%), aggregated $\mathrm{N}_{2} \mathrm{O}$ emissions from agricultural soils comprise an even larger share (46\%), mainly as a consequence of nitrification and denitrification processes driven by synthetic and organic fertilizer application to the agricultural land (Soussana et al., 2007; FAOSTAT, 2017). Manure related $\mathrm{N}_{2} \mathrm{O}$ and $\mathrm{CH}_{4}$ emissions in Europe, comprising $\mathrm{CH}_{4}$ and $\mathrm{N}_{2} \mathrm{O}$ emissions from manure management along with $\mathrm{N}_{2} \mathrm{O}$ emissions from organic fertilizer and manure from grazing animals that is left on pastures, account for 30\% of the total agricultural GHG emissions (FAOSTAT, 2017).

The net ecosystem exchange of $\mathrm{CO}_{2}$ is the most important constituent of the grassland $\mathrm{C}$ cycle. The role of the $\mathrm{CO}_{2}$ flux for the GHG budget can become even more pronounced in grasslands, as such ecosystems are often limited by soil $\mathrm{N}$ availability, and $\mathrm{N}$ addition during fertilization increases the $\mathrm{CO}_{2}$ sink more than the $\mathrm{N}_{2} \mathrm{O}$ and $\mathrm{CH}_{4}$ sources (Gomez-Casanovas et al., 2016). Although the $\mathrm{CO}_{2}$ flux in response to abiotic, biotic and management drivers was studied previously (e.g., Wohlfahrt et al., 2008a; Peichl et al., 2013), direct measurements (of one year or longer) of $\mathrm{N}_{2} \mathrm{O}$ and $\mathrm{CH}_{4}$ grassland fluxes in combination with $\mathrm{CO}_{2}$ fluxes are still rare (Kroon et al., 2010; Hörtnagl \& Wohlfahrt, 2014; Merbold et al., 2014).

The accurate quantification of the three GHGs $\mathrm{CO}_{2}, \mathrm{~N}_{2} \mathrm{O}$ and $\mathrm{CH}_{4}$ is relevant for climate policy. Following the Paris Climate Agreement (UNFCCC, 2015), each signing partner country is requested to accurately report GHG emissions from different sectors, e.g. from agriculture, forestry and other land use (AFOLU). In addition, countries are required to identify potential

This article is protected by copyright. All rights reserved. 
GHG mitigation options. However, long-term measurements of GHG emissions from grasslands, which are part of the AFOLU sector, remain scarce. In-situ data have the potential to adequately reflect the small-scale variability of GHG emissions at farm scale, needed to give specific mitigation recommendations to stakeholders. In addition, they provide the data basis for biogeochemical process model development and validation. Availability and continuity of such direct ecosystem GHG flux measurements is crucial for assessing the GHG reduction potential of different management strategies (Luyssaert et al., 2014).

In this study, we examined the GHG emission intensity of meadows and pastures. To this end, we analyzed available GHG measurements of 14 differently managed grassland sites in Central Europe across different environmental settings. Our specific objectives were (1) to provide an overview of currently available in-situ GHG measurements over managed grasslands, (2) to test the applicability of soil temperature and water-filled pore space, two key parameters for soil biogeochemistry and widely available in combination with flux measurements, for the prediction of $\mathrm{N}_{2} \mathrm{O}$ and $\mathrm{CH}_{4}$ fluxes across grassland sites, (3) to quantify the impact of fertilizer application on observed $\mathrm{N}_{2} \mathrm{O}$ and $\mathrm{CH}_{4}$ emissions, and (4) to provide net GHG balances and $\mathrm{N}_{2} \mathrm{O}-\mathrm{N}$ emission factors for all sites by gap-filling direct measurements at ecosystem scale.

\section{Materials and Methods}

This synthesis paper investigated $\mathrm{CO}_{2}, \mathrm{CH}_{4}$ and $\mathrm{N}_{2} \mathrm{O}$ fluxes from ten Central European grasslands along an elevation gradient (Table 1). Four out of the ten grasslands (FR-LAQ, CH-FRU, DEFEN, CH-CHA) were divided into two separate areas with different management, leading to 14 grassland sites in total.

This article is protected by copyright. All rights reserved. 


\section{Research sites and management}

The research sites span an altitudinal gradient from 400 - 1978 m a.s.l in Central Europe, with mean annual temperatures (MAT) ranging between -1.4 and $9.1^{\circ} \mathrm{C}$ and mean annual precipitation (MAP) ranging between 852 and $1682 \mathrm{~mm}$ (Table 1). Sites included in this study, listed in altitudinal order from highest to lowest, were the extensively managed site CH-AWS (1978 m a.s.1.), the extensive pasture AT-STU-P (1870 $\mathrm{m}$ a.s.l.), the extensive meadow AT-STU-M (1820 $\mathrm{m}$ a.s.1.), the semi-natural grassland site Laqueuille that was divided into two adjacent paddocks with intensive (FR-LAQ-I) and extensive (FR-LAQ-E) management (1040 m a.s.l.), the subdivided mountain rangeland at Früebüel, which consisted of the intensively managed site CHFRU-I and the extensive site CH-FRU-E (982 $\mathrm{m}$ a.s.l.), the intensively managed AT-NEU (970 m a.s.1.), the extensive meadow DE-GAP (734 $\mathrm{m}$ a.s.1.), Fendt with an intensively and extensively managed paddock (DE-FEN-I, DE-FEN-E, $600 \mathrm{~m}$ a.s.l.), and the intensive site Chamau, which was subdivided into two areas during a chamber measurement campaign in $2010 / 2011$ (CHCHA-I1, CH-CHA-I2), while in 2012, $\mathrm{CH}_{4}$ and $\mathrm{N}_{2} \mathrm{O}$ fluxes were measured using the eddy covariance technique covering both areas (CH-CHA, $393 \mathrm{~m}$ a.s.l.) (Table 1).

Management practices carried out at the studied grassland sites included the application of inorganic and organic fertilizer, mowing and grazing. The amount and type of fertilizer, the frequency of cutting and the intensity and duration of grazing at the different sites were highly variable (Table 1). Thirteen of the 14 sites were fertilized between one and six times per year. Organic fertilizer was applied at 12 of the 14 sites, ranging from 33 to $365 \mathrm{~kg} \mathrm{~N} \mathrm{ha}^{-1} \mathrm{yr}^{-1}$. The amount of organic fertilizer spread at CH-AWS when cattle were grazing was unknown. Synthetic fertilizer was applied only at FR-LAQ-I (214 $\left.\mathrm{kg} \mathrm{N} \mathrm{ha}^{-1} \mathrm{yr}^{-1}\right)$ and CH-CHA (2012: $17 \mathrm{~kg}$

$\mathrm{N} \mathrm{ha}^{-1} \mathrm{yr}^{-1}$ ), but only at CH-CHA in combination with slurry. Of the 14 sites, only one was not

This article is protected by copyright. All rights reserved. 
fertilized during the investigated time period (FR-LAQ-E). However, for all grazed sites additional $\mathrm{N}$ input came from excretion of grazing animals onto the pasture.

Ten sites were cut at least once per year, whereas some intensively managed sites were cut up to five times per year. Ten sites were grazed by cattle and / or sheep between $1-170$ days $\mathrm{yr}^{-1}$. $\mathrm{CH}^{-}$ CHA was ploughed for grassland restoration and resown in early 2012. Further details including key references for each site are given in Table 1.

\section{Flux measurements}

The net ecosystem exchange of the three major GHGs $\left(\mathrm{CO}_{2}, \mathrm{~N}_{2} \mathrm{O}\right.$, and $\left.\mathrm{CH}_{4}\right)$ was calculated using the eddy covariance (EC, Baldocchi et al., 1988) or chamber techniques, whereby for the latter either automatic (AC) or manual chambers (MC) were used (Table 1). Data availability and temporal resolution of measurements of the three targeted GHGs varied considerably across all sites. $\mathrm{N}_{2} \mathrm{O}$ fluxes were available from all 14 sites, while $\mathrm{CO}_{2}$ fluxes were available from ten and $\mathrm{CH}_{4}$ fluxes from 13 sites (Figure 1). Measurement campaigns at the sites lasted between six months (AT-STU-P) and more than five years (FR-LAQ-I, FR-LAQ-E) (Table S2).

Measurements covering all three GHGs over at least one full year were available from eight sites, with results from two sites based on continuous EC measurements (AT-NEU, CH-CHA) and from six sites based on EC in combination with MC measurements (CH-AWS, CH-FRU-I, CHFRU-E, DE-FEN-I, CH-CHA-I1, CH-CHA-I2,). $\mathrm{CO}_{2}$ measurements for CH-AWS were only available during the growing season. Two sites had $\mathrm{CO}_{2}$ and $\mathrm{N}_{2} \mathrm{O}$ data available for multiple years, but no (FR-LAQ-E) or limited (FR-LAQ-I during two grazing seasons) $\mathrm{CH}_{4}$ measurements. Measurements of $\mathrm{N}_{2} \mathrm{O}$ and $\mathrm{CH}_{4}$ without simultaneous $\mathrm{CO}_{2}$ measurements were carried out at four sites, either over multiple years (DE-GAP, DE-FEN-E) or over one growing 
season only (AT-STU-P, AT-STU-M). Generally, data coverage was lowest for sites sampled with MCs (20 - 93 measurement days) and highest for $\mathrm{AC}$ and $\mathrm{EC}$ sites (318 - 1373 measurement days). Additional details on flux calculation methods as well as site and instrument setup are given in Table 1 and in the Supplement.

Daily average (DA) flux values were used for analyses in this study. Due to the different temporal resolutions of the measurement methods, the calculation of DA fluxes for each site and day followed different approaches: for chamber measurements, mean values across all replicates were calculated. When at least one replicate average was available for a given day (MC, AC), the flux was assumed to be representative for the whole day (24 hours). For EC data, daily average fluxes were calculated from a minimum of 21 half-hourly flux values. Applying these minimum thresholds resulted in a tradeoff between overall data availability and representativity of a given calculated daily average flux.

Flux rates in this study are given as $\mathrm{mg} \mathrm{CO}_{2} \mathrm{~m}^{-2} \mathrm{~h}^{-1}$ for $\mathrm{CO}_{2}$, and $\mu \mathrm{g} \mathrm{m}^{-2} \mathrm{~h}^{-1}$ for $\mathrm{N}_{2} \mathrm{O}$ and $\mathrm{CH}_{4}$. Fluxes are reported following the convention used in micrometeorology, where positive fluxes mean a transport from the ecosystem to the atmosphere, negative fluxes mean the opposite.

\section{Gap-filling}

Fluxes were gap-filled for the calculation of site-specific GHG budgets, $\mathrm{N}_{2} \mathrm{O}-\mathrm{N}$ emission factors (EFs) and NGBs. While $\mathrm{CO}_{2}$ fluxes were gap-filled following Reichstein et al. (2005), the gapfilling (GF) for $\mathrm{N}_{2} \mathrm{O}$ and $\mathrm{CH}_{4}$ was based on a running median (RM) approach, which comprised several steps. First, the continuous RM DA flux was calculated for each site and GHG using predefined time windows of varying lengths, selected as to best describe the measured DA flux pattern over the course of a full year. For sites where multiple years of measured $\mathrm{N}_{2} \mathrm{O}$ data were

This article is protected by copyright. All rights reserved. 
available, the calculation of the RM was based on the average of all available fluxes for a specific day of the year, except for $\mathrm{CH}-\mathrm{CHA}$, where the ploughing year 2012 and the following year 2013 were treated separately. Typical sizes of the RM time window were $15-120,60$, 60 days for MC, AC, EC data, respectively (Table 1). Potential remaining data gaps at the beginning and end of specific years were then filled by repeating the median flux value closest to the gap. This yielded a continuous estimate for the RM flux of a site for each day and year. The main reason for choosing the RM approach was that it is less sensitive to outliers, i.e. to sharp emission peaks in the data, in contrast to filling data gaps with the arithmetic mean or by linear interpolation. Second, the RM daily average flux time series was then used to substitute data gaps in the measured daily average time series with the corresponding RM value of the given day of the year, resulting in complete, gap-filled $\mathrm{N}_{2} \mathrm{O}$ and $\mathrm{CH}_{4}$ flux time series for the year. The RM method consequently leads to cumulative fluxes representative for a given site, but it is not suitable for predicting or simulating GHG emission pulses, e.g. as a consequence of management or freeze/thaw periods. Thus, budgets calculated from the RM method are likely to underestimate the "true" budget at a specific site. From the grazed meadow FR-LAQ-I, $\mathrm{CH}_{4}$ measurements were only available during the growing season with cattle present in the measurement footprint. To achieve year-round $\mathrm{CH}_{4}$ budgets, time periods without cattle were gap-filled with a constant, low

$\mathrm{CH}_{4}$ emission value $\left(160 \mu \mathrm{g} \mathrm{m}^{-2} \mathrm{~h}^{-1}\right)$, similar to flux rates observed during ungrazed time periods at another site in an earlier study (Dumortier et al., 2017).

\section{Ancillary data}

Measurements of ancillary data included ambient air temperature (TA in $\left.{ }^{\circ} \mathrm{C}\right)$, soil temperature (TS in ${ }^{\circ} \mathrm{C}$ ), soil water content (SWC in vol. \%), and precipitation (mm) (Table 1). Measured soil

This article is protected by copyright. All rights reserved. 
parameters were bulk density (BD) and $\mathrm{pH}$. SWC was converted to water-filled pore space (WFPS) by first calculating the total porosity (TP) of the soil in percent for each site as

$$
T P=\left(1-\frac{B D}{P D}\right)
$$

where BD is the bulk density for each site and PD is the particle density assumed as $2.65 \mathrm{~g} \mathrm{~cm}^{-3}$. In a second step, TP (\%) was used to calculate WFPS (\%) following

$$
W F P S=\left(\frac{S W C}{T P}\right)
$$

where SWC is the soil water content (volumetric \%) as measured at each site.

\section{Normalization}

In order to identify environmental conditions conducive to enhanced GHG source/sink activity, measured non-gapfilled daily average $\mathrm{N}_{2} \mathrm{O}$ and $\mathrm{CH}_{4}$ fluxes were investigated in relation to different combined classes of the two potential drivers soil temperature (TS) and soil moisture (given in water-filled pore space, WFPS). One approach to account for diverse environmental conditions and soil physical properties while also improving comparability across sites is the normalization of all involved variables to their respective percentile values at site level. Daily average flux values of $\mathrm{N}_{2} \mathrm{O}$ and $\mathrm{CH}_{4}$ fluxes, as well as TS and WFPS measurements at each site were converted to an index in the range 0 to $100 \%$ based on the cumulative empirical probability density function (cePDF) of each variable at each site. That is, the index value corresponds with the percentile value of the original measurements in relation to the site-specific cePDF. These index values were further aggregated in graphical displays by showing the median of the index values from all sites within each aggregation unit. Following this approach facilitated the identification of common emission/deposition sweet spots, i.e. environmental conditions that

This article is protected by copyright. All rights reserved. 
contribute to an increase or decrease of GHG fluxes. The use of strictly linear, site-specific percentile values for sweet spot analyses had the advantage of investigating fluxes in relation to site-specific ranges of potential drivers (Luo et al., 2013).

For the quantification of the fertilization effect, daily average fluxes in the period starting 7 days before and ending 7 days after the event were normalized by the 7-day flux average before the event, not including the day of the event (day 0) (see Figure 8 and 9).

\section{Data analysis}

Site-specific of $\mathrm{N}_{2} \mathrm{O}-\mathrm{N}$ emission factors (EFs) are expressed as the ratio between annual $\mathrm{N}_{2} \mathrm{O}-\mathrm{N}$ budgets after gap-filling and the amount of applied fertilizer. Results from multiple linear regression analyses (MLR) were checked for multicollinearity by inspecting the eigenvalues of soil temperature and water-filled pore space in a correlation matrix. Eigenvalues across all sites were found between 0.37 and 1.63, indicating no multicollinearity problems. The adjusted coefficient of determination $\left(r_{\mathrm{adj}}^{2}\right)$ corresponds to $\mathrm{r}^{2}$ after adjustment based on the degrees of freedom of the respective model, i.e. $r^{2}$ is adjusted to the number of regressors and the sample size. As such, $r_{a d j}^{2}$ is an indicator for the utility of a regression model, especially for MLR models, by describing the explained variation in the dependent variable above what would be expected by chance. Data analyses were based on daily average values. Plots and statistical analyses were done using the free and open source programming language Python (version 3.6.0, Python Software Foundation), including the packages pandas (version 0.20.3; McKinney, 2010), numpy (version 1.13.1; Van Der Walt et al., 2011), matplotlib (version 2.0.2; Hunter, 2007) and statsmodels (version 0.8.0; Seabold \& Perktold, 2010). Significance levels given in regression analyses correspond to the two-tailed $P$-values using Wald Test with t-distribution of the test

This article is protected by copyright. All rights reserved. 
statistic. Sites included in figures and tables of this manuscript are listed in descending order of elevation from top to bottom and left to right. Average values are given \pm standard error of the mean (SEM) where possible.

\section{Results}

\section{Greenhouse gas measurements}

The $\mathrm{CO}_{2}$ flux was available from nine sites and showed highest net $\mathrm{CO}_{2}$ uptake during spring and summer, reflecting time periods of high plant productivity (Figure 2a). During these warmer seasons, measured median fluxes ranged between -1.02 (AT-NEU in spring) and -0.09 mg $\mathrm{CO}_{2}$ $\mathrm{m}^{-2} \mathrm{~h}^{-1}$ (CH-FRU-E in spring), except for spring at $\mathrm{CH}-\mathrm{CHA}$, which was characterized by net $\mathrm{CO}_{2}$ losses (0.12 mg $\left.\mathrm{CO}_{2} \mathrm{~m}^{-2} \mathrm{~h}^{-1}\right)$. Measured $\mathrm{CO}_{2}$ uptake generally decreased during colder months, with measurements indicating small uptake or emission of $\mathrm{CO}_{2}\left(-0.28\right.$ to $\left.0.28 \mathrm{mg} \mathrm{CO}_{2} \mathrm{~m}^{-2} \mathrm{~h}^{-1}\right)$. The average annual $\mathrm{CO}_{2}$ flux across all sites, calculated from gap-filled data, was $-1426 \pm 248 \mathrm{~g}$ $\mathrm{CO}_{2} \mathrm{~m}^{-2} \mathrm{yr}^{-1}$, with strongest $\mathrm{CO}_{2}$ uptake in spring $\left(-855 \pm 80 \mathrm{~g} \mathrm{CO}_{2} \mathrm{~m}^{-2}\right)$, followed by summer ($\left.577 \pm 100 \mathrm{~g} \mathrm{CO}_{2} \mathrm{~m}^{-2}\right)$ and autumn $\left(-131 \pm 83 \mathrm{~g} \mathrm{CO}_{2} \mathrm{~m}^{-2}\right)$. Winter was on average a $\mathrm{CO}_{2}$ source $\left(137 \pm 52 \mathrm{~g} \mathrm{CO}_{2} \mathrm{~m}^{-2}\right)$.

$\mathrm{N}_{2} \mathrm{O}$ was emitted from all grasslands and during all seasons, except for AT-NEU, where small uptake rates of $-2 \mu \mathrm{g} \mathrm{N}_{2} \mathrm{O} \mathrm{m}^{-2} \mathrm{~h}^{-1}$ were recorded during spring (Figure $2 \mathrm{~b}$ ). The median of directly measured seasonal fluxes at the emitting sites ranged between 0.1 (FR-LAQ-I in winter) and 240 $\mu \mathrm{g} \mathrm{N} \mathrm{N}_{2} \mathrm{O}^{-2} \mathrm{~h}^{-1}$ (CH-CHA-I2 in summer). The average annual $\mathrm{N}_{2} \mathrm{O}$ flux across all sites, calculated from gap-filled data was $2664 \pm 1024 \mathrm{mg} \mathrm{N}_{2} \mathrm{O} \mathrm{m} \mathrm{mr}^{-1}$, with strongest emissions in summer $\left(1063 \pm 381 \mathrm{mg} \mathrm{N}_{2} \mathrm{O} \mathrm{m}^{-2}\right)$ and weakest emissions during winter $\left(422 \pm 204 \mathrm{mg} \mathrm{N}_{2} \mathrm{O} \mathrm{m}^{-2}\right)$.

This article is protected by copyright. All rights reserved. 
Median seasonal $\mathrm{CH}_{4}$ fluxes calculated from chamber measurements were generally negative, ranging between -46 (AT-STU-M) and $-6 \mu \mathrm{g} \mathrm{CH}_{4} \mathrm{~m}^{-2} \mathrm{~h}^{-1}$ (DE-FEN-I), indicating uptake of atmospheric $\mathrm{CH}_{4}$ by grassland soils (Figure 2c). Methane chamber emissions were found only during winter at four sites (CH-FRU-I, DE-GAP, CH-CHA-I1, CH-CHA-I2; ranging between 0.3 and $8 \mu \mathrm{g} \mathrm{CH}_{4} \mathrm{~m}^{-2} \mathrm{~h}^{-1}$ ). In contrast to chamber measurements, median $\mathrm{CH}_{4}$ fluxes from EC measurements were all positive during all seasons, with highest emissions observed at FR-LAQ-I during spring when cattle were present within the flux footprint $\left(4565 \mu \mathrm{g} \mathrm{CH}_{4} \mathrm{~m}^{-2} \mathrm{~h}^{-1}\right)$. After gapfilling, the average $\mathrm{CH}_{4}$ flux across all sites, not including FR-LAQ-I, amounted to $36 \pm 85 \mathrm{mg}$ $\mathrm{CH}_{4} \mathrm{~m}^{-2} \mathrm{yr}^{-1}$, with strongest $\mathrm{CH}_{4}$ emissions in autumn $\left(18 \pm 22 \mathrm{mg} \mathrm{CH}_{4} \mathrm{~m}^{-2}\right)$.

\section{Effect of two drivers on $\mathrm{N}_{2} \mathrm{O}$ and $\mathrm{CH}_{4}$ exchange}

The identification of GHG source/sink sweet spots in relation to specific soil moisture and temperature conditions at the site level worked best with sites where flux measurements were taken at high temporal resolution, i.e. based on EC and AC measurements (Figure 3, Figure 4). For example, $\mathrm{N}_{2} \mathrm{O}$ emissions at FR-LAQ-I were highest when WFPS was above 75\% and lowest with TS below $5^{\circ} \mathrm{C}$, conditions during which low emissions could also translate into small uptake of $\mathrm{N}_{2} \mathrm{O}$ (Figure 3a, Table 2). However, other sites deviated from this observation. $\mathrm{N}_{2} \mathrm{O}$ emissions at AT-NEU were highest with TS above $15^{\circ} \mathrm{C}$ or below $5^{\circ} \mathrm{C}$ and WFPS around or below $50 \%$. Similar emission patterns were also found at DE-FEN-E, with highest emissions occurring at TS $>15^{\circ} \mathrm{C}$ or $<5^{\circ} \mathrm{C}$, and lowest $\mathrm{N}_{2} \mathrm{O}$ emissions with WFPS $<50 \%$. CH-CHA was the only site where WFPS frequently exceeded 90\% (interquartile range: $85-94 \%$ ). During these overall wet conditions, when the soil was almost fully water-saturated, observed $\mathrm{N}_{2} \mathrm{O}$ emissions at CH-CHA were low. Chamber measurements at the same site in previous years, prior to grassland restoration, revealed a somewhat contrasting flux pattern, but were performed during generally

This article is protected by copyright. All rights reserved. 
warmer time periods (data not shown). Merging all site-level observations showed that the highest $\mathrm{N}_{2} \mathrm{O}$ percentile flux generally occurred during warm and wet periods, with considerably lower percentile fluxes during colder time periods (Figure 3b).

In comparison to $\mathrm{N}_{2} \mathrm{O}$, the investigation of $\mathrm{CH}_{4}$ at site level revealed flux patterns that in many cases were dominated by uptake of atmospheric $\mathrm{CH}_{4}$ by soils (Figure 4a). Therefore, interpreting flux patterns was more challenging because most sites could act both as a clear sink or a source for $\mathrm{CH}_{4}$ during different time periods. Thus, upper flux percentiles did not necessarily reflect $\mathrm{CH}_{4}$ emission, but equated to low $\mathrm{CH}_{4}$ uptake at some sites. Across 13 investigated sites for which $\mathrm{CH}_{4}$ measurements were available, ten sites were dominated by $\mathrm{CH}_{4}$ uptake, with only two sites (AT-NEU, CH-CHA) showing clear emission patterns, not including FR-LAQ-I (Table 2, Figure 4a). Both DE-FEN-I and DE-FEN-E showed highest $\mathrm{CH}_{4}$ uptake with TS $>15^{\circ} \mathrm{C}$ and WFPS < $50 \%$, weakest $\mathrm{CH}_{4}$ uptake was observed with WFPS above or around 50\% (DE-FEN-I, DE-FENE) and $\mathrm{TS}<10^{\circ} \mathrm{C}(\mathrm{DE}-\mathrm{FEN}-\mathrm{E})$. For AT-NEU, uptake was mainly observed at intermediate WFPS and TS around $10^{\circ} \mathrm{C}$, while highest $\mathrm{CH}_{4}$ emissions occurred with $\mathrm{TS}>10^{\circ} \mathrm{C}$ (Figure $4 \mathrm{a}$ ). Across all sites, the $\mathrm{CH}_{4}$ percentile flux increased with increasing WFPS and decreasing TS (Figure 4b).

Normalized $\mathrm{N}_{2} \mathrm{O}$ and $\mathrm{CH}_{4}$ flux patterns across all sites, based on the same classes of TS and WFPS as shown in Figure $3 \mathrm{~b}$ and Figure $4 \mathrm{~b}$ could well be explained by either TS or WFPS in a simple linear regression (Figure 5). Soil temperature was a significant driver for $\mathrm{N}_{2} \mathrm{O}\left(\mathrm{r}^{2}=0.88, P\right.$ $<0.001)$ and $\mathrm{CH}_{4}$ fluxes $\left(\mathrm{r}^{2}=0.35, P<0.05\right)$. WFPS had high predictive power for $\mathrm{CH}_{4}$ exchange $\left(\mathrm{r}^{2}=0.84, P<0.001\right)$ and was a significant driver for $\mathrm{N}_{2} \mathrm{O}$ fluxes $\left(\mathrm{r}^{2}=0.54, P<0.05\right)$.

In order to test if the predictive power of TS and WFPS for flux percentiles across all sites also succeeds at the site level, multiple linear regression (MLR) and simple linear regression (SLR)

This article is protected by copyright. All rights reserved. 
analyses were performed on measured, log-transformed daily average $\mathrm{N}_{2} \mathrm{O}$ and $\mathrm{CH}_{4}$ fluxes for each site. Data included in these analyses were not gap-filled, measured during snow-free conditions and not directly disturbed by cutting and fertilization management events, i.e. data from the three days directly after a management event were excluded from these analyses (Table 3). The explained variance of $\mathrm{N}_{2} \mathrm{O}$ fluxes in a MLR was low for most sites, with a coefficient of determination $\left(\mathrm{r}^{2}\right)$ of 0.19 on average, ranging between 0.02 (DE-FEN-E) and 0.47 (CH-FRU-E). TS as predictor variable in a SLR at site level generally explained only a small fraction of observed flux patterns (significant $\mathrm{r}^{2}$ between 0.01 and 0.27 ), similarly low values were found for WFPS (significant $\mathrm{r}^{2}$ between 0.01 and 0.29 ).

Similar to $\mathrm{N}_{2} \mathrm{O}$ fluxes, the combined explanatory power of the potential driver variables TS and WFPS for observed $\mathrm{CH}_{4}$ flux patterns was limited $\left(\mathrm{r}^{2}=0.23\right.$, on average), but yielded good results for the extensive high altitude site CH-AWS $\left(r^{2}=0.77\right)$. For the remaining sites, significant $\mathrm{r}^{2}$ ranged between 0.04 (AT-NEU) and 0.40 (CH-FRU-E, DE-GAP). The explained variance for subdivided sites was higher for the less intensively managed part of the grassland. For example, $\mathrm{r}^{2}$ was higher for CH-FRU-E than for CH-FRU-I $\left(r^{2}=0.40\right.$ vs. 0.19), and higher for DE-FEN-E than for DE-FEN-I ( $\mathrm{r}^{2}=0.32$ vs. 0.22$)$. The SLR identified WFPS as a relatively good predictor variable for the high altitude site CH-AWS $\left(r^{2}=0.72\right)$. However, the high predictive power of TS and WFPS for percentile-normalized $\mathrm{N}_{2} \mathrm{O}$ and $\mathrm{CH}_{4}$ fluxes, respectively, across all sites (Figure 5) was not supported by MLR and SLR analyses of log-transformed data at site level.

Regression analyses indicated that the role of the two potential driver variables TS and WFPS in driving $\mathrm{N}_{2} \mathrm{O}$ and $\mathrm{CH}_{4}$ fluxes can be vastly different across sites, i.e. the spatial domain (Table 3). Therefore, in a next step, we analyzed their predictive power for measured, non-gapfilled data in 
the temporal domain. To this end, we investigated the explained variance of observed $\mathrm{N}_{2} \mathrm{O}$ and $\mathrm{CH}_{4}$ fluxes by the combined use of TS and WFPS as predictors in a moving 35-day time window (Figure 6, Figure 7). In order to perform this analysis, long-term data recorded at high temporal resolution were required. This requirement was met by six sites in this study, namely those that used either EC or AC measurements for the quantification of $\mathrm{N}_{2} \mathrm{O}$ or $\mathrm{CH}_{4}$ fluxes (FR-LAQ-I, FRLAQ-E, AT-NEU, DE-FEN-I, DE-FEN-E, CH-CHA). The analysis revealed that the role of WFPS and TS as driving variables of observed fluxes varied considerably over the course of the measurement periods. During the growing season, both variables often predicted observed $\mathrm{N}_{2} \mathrm{O}$ fluxes with high precision and significance $(P<0.05)$, with maximum $r^{2}$ ranging between 0.71 (AT-NEU in summer 2010) and 0.90 (DE-FEN-E in summer 2012) for individual sites (Figure 6). In contrast, their explanatory value was low and often close to zero during cold time periods and snow cover when $\mathrm{N}_{2} \mathrm{O}$ fluxes were low. Especially for $\mathrm{N}_{2} \mathrm{O}$ fluxes, results during certain time windows were often in strong contrast to results from the MLR analyses in Table 3. For example, at DE-FEN-E, WFPS and TS were poorly correlated with $\mathrm{N}_{2} \mathrm{O}$ fluxes with all measurements considered $\left(\mathrm{r}^{2}=0.02\right.$, Table 3$)$, but both predictors explained up to $90 \%$ of observed fluxes between 25 June and 30 July 2012 at the same site (Figure 6). Similar results were also found for $\mathrm{CH}_{4}$, with maximum $\mathrm{r}^{2}$ between 0.41 (AT-NEU autumn/winter 2010) and 0.92 (DE-FEN-I and DE-FEN-E in summer/autumn 2013) in certain time windows (Figure 7). Generally, using TS and WFPS as predictors for measured fluxes in pre-defined time windows yielded better and more significant results for $\mathrm{N}_{2} \mathrm{O}$ than for $\mathrm{CH}_{4}$ (Figure 6, Figure 7).

\section{Fertilization effect on $\mathrm{N}_{2} \mathrm{O}$ and $\mathrm{CH}_{4}$ fluxes}

The availability of flux measurements for the time period before, during and after fertilization events allowed for an evaluation of the management impact on observed $\mathrm{N}_{2} \mathrm{O}$ and $\mathrm{CH}_{4}$ exchange.

This article is protected by copyright. All rights reserved. 
Flux data around multiple fertilization dates were available from three grasslands, all of which used slurry as fertilizer (DE-FEN-I, DE-FEN-E, CH-CHA). Slurry application resulted in clear $\mathrm{N}_{2} \mathrm{O}$ emission peaks at all three sites either on the day of application or during the following 7 days (Figure 8). In comparison to the seven days preceding the application, $\mathrm{N}_{2} \mathrm{O}$ emissions across all sites were on average 10 times higher on the day of fertilization, 5 times higher one day after fertilization, and 2 times higher over the following six days. $\mathrm{N}_{2} \mathrm{O}$ fluxes stayed elevated for a few days after the event, reaching pre-fertilization flux rates again on day $3-7$ after fertilizer application. Average $\mathrm{N}_{2} \mathrm{O}$ emission rates during the seven days before management for $\mathrm{CH}-\mathrm{CHA}$ (125 $\pm 45 \mu \mathrm{g} \mathrm{N}_{2} \mathrm{O} \mathrm{m}{ }^{-2} \mathrm{~h}^{-1}$ on average) were high in comparison to DE-FEN-I $\left(23 \pm 7 \mu \mathrm{g} \mathrm{N}_{2} \mathrm{O} \mathrm{m}^{-2}\right.$ $\left.\mathrm{h}^{-1}\right)$ and DE-FEN-E $\left(13 \pm 5 \mu \mathrm{g} \mathrm{N} \mathrm{O} \mathrm{m}^{-2} \mathrm{~h}^{-1}\right)$.

The high $\mathrm{N}_{2} \mathrm{O}$ emissions after fertilization of the grassland had a strong impact on the total amount of $\mathrm{N}_{2} \mathrm{O}-\mathrm{N}$ that was emitted from the respective grassland to the atmosphere over the course of the year. For example, cumulative $\mathrm{N}_{2} \mathrm{O}-\mathrm{N}$ emissions from the grassland at $\mathrm{CH}-\mathrm{CHA}$ amounted to $2.6 \mathrm{~kg} \mathrm{~N}^{-1}{ }^{-1}$ over the course of 2013 (Table 6). During the same year, $0.7 \mathrm{~kg} \mathrm{~N} \mathrm{ha}^{-1}$ were emitted immediately after four fertilization events, i.e. $\mathrm{N}_{2} \mathrm{O}-\mathrm{N}$ emissions over the course of the fertilization day and the following week after subtraction of pre-fertilization flux rates, which is equal to $28 \%$ of the annual cumulative $\mathrm{N}_{2} \mathrm{O}-\mathrm{N}$ emissions. Hence, each fertilizer application resulted in immediate $\mathrm{N}_{2} \mathrm{O}-\mathrm{N}$ emissions of $7 \pm 1 \%$ of the annual cumulative loss. Similar results were also found at DE-FEN-I between 2012 and 2014 (7 $\pm 2 \%$ per fertilization), demonstrating the impact of fertilizer application on the annual $\mathrm{N}_{2} \mathrm{O}$ budget.

Similar to $\mathrm{N}_{2} \mathrm{O}$ emissions, $\mathrm{CH}_{4}$ fluxes were elevated on the day of slurry application (Figure 9). However, methane emissions decreased earlier in comparison to $\mathrm{N}_{2} \mathrm{O}$ emissions and reached prefertilization values one or two days after fertilization. Unlike $\mathrm{N}_{2} \mathrm{O}$, the grasslands at DE-FEN-I

This article is protected by copyright. All rights reserved. 
and DE-FEN-E were a $\mathrm{CH}_{4}$ sink before fertilizer application, albeit flux averages were characterized by high standard errors. For DE-FEN-I and DE-FEN-E, average $\mathrm{CH}_{4}$ uptake rates of $-11 \pm 3$ and $-26 \pm 19 \mu \mathrm{g} \mathrm{m}^{-2} \mathrm{~h}^{-1}$, respectively, were found over the course of the seven days preceding management. Manure application turned the two grasslands from a sink to a source of $\mathrm{CH}_{4}$, with high emissions on the day of fertilization $\left(1271 \pm 440\right.$ and $212 \pm 250 \mu \mathrm{g} \mathrm{m}^{-2} \mathrm{~h}^{-1}$, respectively) and a rapid decrease of $\mathrm{CH}_{4}$ emissions in the following week $(-4 \pm 8$ and $-25 \pm 16$ $\mu \mathrm{g} \mathrm{m}^{-2} \mathrm{~h}^{-1}$, respectively). In contrast, the grassland at $\mathrm{CH}-\mathrm{CHA}$ was mostly a $\mathrm{CH}_{4}$ source before fertilization $\left(17 \pm 78 \mu \mathrm{g} \mathrm{m}^{-2} \mathrm{~h}^{-1}\right)$, with elevated emission peaks on the day of slurry application $\left(637 \pm 239 \mu \mathrm{g} \mathrm{m}^{-2} \mathrm{~h}^{-1}\right)$ and $\mathrm{CH}_{4}$ emission rates that stayed elevated during the week after fertilization $\left(228 \pm 72 \mu \mathrm{g} \mathrm{m}^{-2} \mathrm{~h}^{-1}\right)$.

\section{GHG budgets}

In-situ measurements over multiple years in combination with subsequent gap-filling allowed for the calculation of site-specific annual GHG budgets (Table 4). During the investigated time periods in this study, all ten sites for which the $\mathrm{CO}_{2}$ flux was quantified for at least one year were

a $\mathrm{CO}_{2}$ sink, ranging between $-2806 \mathrm{~g} \mathrm{CO}_{2} \mathrm{~m}^{-2} \mathrm{yr}^{-1}$ (CH-FRU-I) and $-91 \pm 20 \mathrm{~g} \mathrm{CO}_{2} \mathrm{~m}^{-2} \mathrm{yr}^{-1}$ (ATNEU, 2010-2011). All 14 sites with $\mathrm{N}_{2} \mathrm{O}$ measurements were a $\mathrm{N}_{2} \mathrm{O}$ source, emitting between 18 $\mathrm{g} \mathrm{CO}_{2} \mathrm{~m}^{-2} \mathrm{yr}^{-1}$ (AT-STU-P) and $638 \pm 519 \mathrm{~g} \mathrm{CO}_{2} \mathrm{~m}^{-2} \mathrm{yr}^{-1}$ (CH-CHA, 2012-2013). Findings for the 13 sites with $\mathrm{CH}_{4}$ measurements were more diverse, with nine sites acting as a methane sink, ranging between -9 g CO $\mathrm{CO}_{2}$-eq. $\mathrm{m}^{-2} \mathrm{yr}^{-1}(\mathrm{CH}-\mathrm{AWS}, \mathrm{AT}-\mathrm{STU}-\mathrm{M})$ and $-1 \pm 2 \mathrm{~g} \mathrm{CO}_{2}$-eq. $\mathrm{m}^{-2} \mathrm{yr}^{-1}$ (DE-GAP, 2012-2013; DE-FEN-I, 2012-2014). Three sites (AT-NEU, DE-FEN-I, CH-CHA) were a $\mathrm{CH}_{4}$ source ( 3 to $41 \mathrm{CO}_{2}$-eq. $\mathrm{m}^{-2} \mathrm{yr}^{-1}$ ). Strongest $\mathrm{CH}_{4}$ emissions were found for the heavily grazed FR-LAQ-I, where cattle were present in the EC footprint, amounting to $488 \pm 100 \mathrm{CO}_{2}$ eq. $\mathrm{m}^{-2} \mathrm{yr}^{-1}$ on average between 2010 and 2011 (Table 4).

This article is protected by copyright. All rights reserved. 
The full NGB was calculated for nine sites where concurrent measurements of all three GHGs $\left(\mathrm{CO}_{2}, \mathrm{~N}_{2} \mathrm{O}, \mathrm{CH}_{4}\right)$ were available. Despite the offset of $\mathrm{CO}_{2}$ uptake by mainly $\mathrm{N}_{2} \mathrm{O}$ and to some extent $\mathrm{CH}_{4}$ emissions, the NGB of the grasslands was strongly negative, with minimum and maximum $\mathrm{CO}_{2}$-eq. uptake of $-58 \pm 32 \mathrm{~g} \mathrm{CO}_{2}$-eq. $\mathrm{m}^{-2} \mathrm{yr}^{-1}$ (AT-NEU, 2010-2011) and $-2761 \mathrm{~g}$ $\mathrm{CO}_{2}$-eq. $\mathrm{m}^{-2} \mathrm{yr}^{-1}$ (CH-FRU-I), respectively (Table 4). The annual $\mathrm{CO}_{2}$ sink strength of the grasslands was offset by concurrent $\mathrm{N}_{2} \mathrm{O}$ and $\mathrm{CH}_{4}$ fluxes by between $2 \%(\mathrm{CH}-\mathrm{FRU}-\mathrm{I})$ and $48 \%$ (FR-LAQ-I, 2008-2013). On average across all sites, the $\mathrm{CO}_{2}$ flux offset amounted to $21 \pm 6 \%$ (Table 4).

The fluxes of all three GHGs $\left(\mathrm{CO}_{2}, \mathrm{~N}_{2} \mathrm{O}\right.$ and $\left.\mathrm{CH}_{4}\right)$ were generally characterized by strong interannual variability (Table 4). For example, $\mathrm{CO}_{2}$ uptake at FR-LAQ-I between 2008 and 2011 was found between -1537 and $-814 \mathrm{~g} \mathrm{CO}_{2} \mathrm{~m}^{-2} \mathrm{yr}^{-1}$. During the same time period, $\mathrm{N}_{2} \mathrm{O}$ emissions (between 48 and $247 \mathrm{~g} \mathrm{CO}_{2}$-eq. $\mathrm{m}^{-2} \mathrm{yr}^{-1}$ ) offset the $\mathrm{CO}_{2}$ uptake by $6-17 \%$. The biggest difference between years was found for $\mathrm{CH}-\mathrm{CHA}$, where grassland restoration in 2012 included ploughing, sowing, fertilizer and pesticide application as well as regular harvests. In the same year, the first resowing after ploughing failed and vegetation was almost absent until summer. The NGB of CH-CHA during the restoration year 2012 amounted to $2446 \mathrm{~g} \mathrm{CO}_{2}$-eq. $\mathrm{m}^{-2}$-the highest across all sites-as a consequence of high $\mathrm{CO}_{2}\left(1246 \mathrm{~g} \mathrm{CO}_{2} \mathrm{~m}^{-2}\right)$ and $\mathrm{N}_{2} \mathrm{O}$ emissions (1157 g CO 2 -eq. $\mathrm{m}^{-2}$ ), along with relatively low $\mathrm{CH}_{4}$ emissions (43 $\mathrm{g} \mathrm{CO}_{2}$-eq. $\mathrm{m}^{-2}$; Table 4$)$. However, in 2013, CH-CHA changed from being a GHG source to a strong GHG sink $\left(-4514 \mathrm{~g} \mathrm{CO}_{2}\right.$-eq. $\mathrm{m}^{-}$ ${ }^{2}$ ), with high $\mathrm{CO}_{2}$ uptake $\left(-4671 \mathrm{~g} \mathrm{CO}_{2} \mathrm{~m}^{-2}\right)$ and considerably lower $\mathrm{N}_{2} \mathrm{O}$ emissions $\left(119 \mathrm{~g} \mathrm{CO}_{2^{-}}\right.$ eq. $\left.\mathrm{m}^{-2}\right)$, while $\mathrm{CH}_{4}$ emissions remained similar $\left(38 \mathrm{~g} \mathrm{CO}_{2}\right.$-eq. $\left.\mathrm{m}^{-2}\right)$. The inter-annual variability of $\mathrm{CH}_{4}$ fluxes was generally lower than that of $\mathrm{CO}_{2}$ and $\mathrm{N}_{2} \mathrm{O}$ fluxes (Table 4).

This article is protected by copyright. All rights reserved. 
Historically, considerably more measurements are available for grassland $\mathrm{CO}_{2}$ fluxes, while data for $\mathrm{N}_{2} \mathrm{O}$ and $\mathrm{CH}_{4}$ remain still relatively sparse. Therefore, we set site-specific budgets presented in this study in relation to previous studies that investigated $\mathrm{N}_{2} \mathrm{O}$ and $\mathrm{CH}_{4}$ exchange over grasslands (Table 5). Out of 46 sites with $\mathrm{N}_{2} \mathrm{O}$ measurements (including sites in this study), 43 sites were on average $\mathrm{N}_{2} \mathrm{O}$ sources, albeit over sometimes vastly different measurement campaign lengths (Table 5). In the literature, we found $\mathrm{N}_{2} \mathrm{O}$ fluxes from 13 European grasslands where measurements covered at least one full year and management was similar to sites investigated in this study (grasslands with ID 23, 24, 32, 34, 38-40, 44, 45, 49-52 in Table 5). At these sites, the overall yearly flux average amounted to $43 \pm 21 \mu \mathrm{g} \mathrm{N}_{2} \mathrm{O} \mathrm{m}^{-2} \mathrm{~h}^{-1}$, similar to average fluxes of $55 \pm$ $21 \mu \mathrm{g} \mathrm{N}_{2} \mathrm{O} \mathrm{m} \mathrm{m}^{-2} \mathrm{~h}^{-1}$ from the twelve sites with year-round measurements in this study (Table 5). The comparison of $\mathrm{CH}_{4}$ fluxes across sites is more challenging, as some sites reported $\mathrm{CH}_{4}$ flux rates with or without considering grazing animals in the investigated area (Table 5). We found that $\mathrm{CH}_{4}$ flux rates from EC measurements for the grazed site FR-LAQ-I (yearly average: $1639 \pm$ $336 \mu \mathrm{g} \mathrm{CH}_{4} \mathrm{~m}^{-2} \mathrm{~h}^{-1}$ ) were comparable to sites that used the $\mathrm{SF}_{6}$ tracer technique (ID 52: $1021 \mu \mathrm{g}$ $\mathrm{CH}_{4} \mathrm{~m}^{-2} \mathrm{~h}^{-1}$, ID 44: $1288 \mu \mathrm{g} \mathrm{CH}_{4} \mathrm{~m}^{-2} \mathrm{~h}^{-1}$; Soussana et al., 2007b) and to a recent EC study at a Belgian pasture with cattle in the flux footprint (ID 30: $1107 \mu \mathrm{g} \mathrm{CH}_{4} \mathrm{~m}^{-2} \mathrm{~h}^{-1}$; Dumortier et al., 2017b). Methane emissions found for FR-LAQ-I were also in the same order of magnitude as emissions from a fen meadow (ID 40, Kroon et al., 2010) and a peatland pasture (ID 29, Baldocchi et al., 2012), but much lower than emissions from a flooded grassland (ID 20, Hernandez et al., 2014). Excluding peatlands, $\mathrm{CH}_{4}$ fluxes were generally low and found between -59 and $136 \mu \mathrm{g} \mathrm{CH}_{4} \mathrm{~m}^{-2} \mathrm{~h}^{-1}$, when cattle were not considered in flux calculations. In total, 17 of 41 sites with $\mathrm{CH}_{4}$ measurements, including sites in this study, reported uptake over yearly or shorter time horizons (Table 5).

This article is protected by copyright. All rights reserved. 
The availability of gap-filled $\mathrm{N}_{2} \mathrm{O}$ measurements for all ten fertilized sites in combination with detailed information about the amount of fertilizer applied to the grassland enabled the calculation of yearly $\mathrm{N}_{2} \mathrm{O}-\mathrm{N}$ emission factors (EFs; Table 6). After gap-filling, $\mathrm{N}_{2} \mathrm{O}$ budgets for a total of 21 years were available. Minimum cumulative $\mathrm{N}_{2} \mathrm{O}-\mathrm{N}$ emissions as well as the lowest EF were found for AT-NEU in $2010\left(0.19 \mathrm{~kg} \mathrm{~N} \mathrm{ha}^{-1}\right.$; EF: 0.1\%), while maximum emissions and the highest EF were found for CH-CHA during the restauration year in $2012\left(24.70 \mathrm{~kg} \mathrm{~N} \mathrm{ha}^{-1}\right.$; EF: $8.6 \%$ ). For the sites where several years of data were available, cumulative $\mathrm{N}_{2} \mathrm{O}-\mathrm{N}$ emissions and EFs were found to vary between years. For example, emissions ranged from 0.57 to $5.28 \mathrm{~kg} \mathrm{~N} \mathrm{ha}^{-}$ ${ }^{1} \mathrm{yr}^{-1}$ at FR-LAQ-I between 2008 and 2013, corresponding to EFs of $0.3-2.5 \%$. Our findings indicate that the ten fertilized sites in this study emitted on average $1.8 \pm 0.5 \%$ of the applied fertilizer $\mathrm{N}$ back to the atmosphere (Table 6).

\section{Discussion}

Soil environmental conditions can influence $\mathrm{N}_{2} \mathrm{O}$ and $\mathrm{CH}_{4}$ fluxes by providing ideal conditions for GHG producing or consuming microbial communities (Li et al., 1992; Holtan-Hartwig et al., 2002; Barnard et al., 2005; Dijkstra et al., 2013). Therefore, we expected clear relationships between soil conditions and magnitude of fluxes across timescales. However, regression analyses for site-level flux observations revealed low or inconsistent explanatory power of TS and WFPS (Table 3, Figure 6, Figure 7). The role of the two variables as flux drivers became more apparent after identification of site-specific GHG sweet spots (Figure 3, Figure 4). Low $\mathrm{N}_{2} \mathrm{O}$ emissions at $\mathrm{CH}-\mathrm{CHA}$ during wet conditions could be the consequence of increased $\mathrm{N}_{2} \mathrm{O}$ reduction to $\mathrm{N}_{2}$ during denitrification compared to production (Figure 3a). When the soil water content is high, the available time for the reduction of $\mathrm{N}_{2} \mathrm{O}$ to $\mathrm{N}_{2}$ during the last step of denitrification is increased, reducing $\mathrm{N}_{2} \mathrm{O}$ release to the atmosphere (Clough et al., 2005; Wu et al., 2013). The

This article is protected by copyright. All rights reserved. 
clear $\mathrm{N}_{2} \mathrm{O}$ uptake in intermediate TS classes at AT-NEU indicated time periods when $\mathrm{N}_{2} \mathrm{O}$ reduction in the soil exceeded concurrent $\mathrm{N}_{2} \mathrm{O}$ production (Figure 3a; Chapuis-Lardy et al., 2007; Hörtnagl \& Wohlfahrt, 2014). However, based on available data it was not possible to conclude whether the observed net uptake was the consequence of increased reduction of $\mathrm{N}_{2} \mathrm{O}$, e.g. due to increased respiration of heterotrophic bacteria, or reduced $\mathrm{N}_{2} \mathrm{O}$ production rates, e.g. due to cool temperatures (Chapuis-Lardy et al., 2007). Still, at AT-NEU, the observation of clear $\mathrm{N}_{2} \mathrm{O}$ uptake with TS $<10^{\circ} \mathrm{C}$ and WFPS $<50 \%$ but clear $\mathrm{N}_{2} \mathrm{O}$ emission at TS $>10^{\circ} \mathrm{C}$ during similar soil moisture conditions suggests that reduced $\mathrm{N}_{2} \mathrm{O}$ production rates were the main driver behind measured net $\mathrm{N}_{2} \mathrm{O}$ uptake in this soil moisture range. At the same time, $\mathrm{N}_{2} \mathrm{O}$ uptake at relatively high WFPS $>50 \%$ could be mainly the consequence of increased reduction rates (Figure 3a; $\mathrm{Wu}$ et al., 2013).

Generally, the warming effect on $\mathrm{N}_{2} \mathrm{O}$ fluxes was inconsistent at site level, similar to findings from other studies (e.g., Bijoor et al., 2008; Hu et al., 2010). Across all sites, the clear relationship between $\mathrm{N}_{2} \mathrm{O}$ fluxes and TS indicated that increasing temperature fuels denitrification turnover processes in the soil, leading to enhanced $\mathrm{N}_{2} \mathrm{O}$ emissions (Figure $3 \mathrm{~b}$, Figure 5a). Elevated $\mathrm{N}_{2} \mathrm{O}$ fluxes at low TS were probably the consequence of emission bursts during freeze/thaw cycles (Risk et al., 2013). For $\mathrm{CH}_{4}$, reduced percentile fluxes at high TS in combination with relatively low WFPS both across all grassland sites (Figure 5b) and at the sitelevel (e.g. DE-FEN-E, Figure 4) are in contrast to findings for wetlands, rice paddies and aquatic ecosystems (Yvon-Durocher et al., 2014), but similar to findings for montane grasslands (Unteregelsbacher et al., 2013). The strong correlation between $\mathrm{CH}_{4}$ fluxes and WFPS is supported by previous studies (Le Mer \& Roger, 2001; Wang et al., 2015; Hofmann et al., 2016).

This article is protected by copyright. All rights reserved. 
Site-specific properties of managed grasslands have the potential to change over relatively short timescales, depending on the frequency and intensity of management events along with environmental conditions. For example, trampling by grazing animals or use of heavy machinery can increase soil compaction and negatively impact soil structure (Ball, 2013). This in turn can affect soil conditions crucial to the production or consumption of GHGs in the soil, such as WFPS. Furthermore, the input of external fertilizer affects nutrient availability in the soil to varying extends and can also impact soil $\mathrm{pH}$, depending on fertilizer type and amount as well as the timing of its application (Saggar et al., 2013). Thus, GHG emissions/deposition sweet spots are not only different among sites (Figure 3, Figure 4), but are also most likely not persistent, depending on applied management strategies, environmental conditions and shifting microbial communities in response thereof (Jones et al., 2014). The detection of sweet spots is therefore of high interest for developing site-specific GHG mitigation strategies, which need to be adapted over the course of a year. For example, the knowledge about sweet spots could assist in scheduling site-specific fertilization dates in such a way that fertilizer is only applied during time periods with low GHG emission impact, i.e. when the normalized flux in specific combined classes of the two potential drivers TS and WFPS is known to be low (Figure 3, Figure 4). In addition, significant relationships between normalized fluxes and potential drivers across sites indicated that site-specific data normalization prior to analyses could facilitate the detection of correlations (Figure 5) and thus improve methods for calculating GHG budgets on a continental scale.

The application of slurry coincided with elevated $\mathrm{N}_{2} \mathrm{O}$ emissions (Figure 8), which is in accordance with findings in earlier studies (Neftel et al., 2010; Jones et al., 2011). Increased $\mathrm{N}_{2} \mathrm{O}$ emissions were expected, as $\mathrm{N}$ input via fertilization constitutes the most concentrated input of 
anthropogenic $\mathrm{N}$, with high soil $\mathrm{N}$ availability fueling $\mathrm{N}_{2} \mathrm{O}$ production by nitrifying/denitrifying bacterial communities (Firestone \& Davidson, 1989; Davidson, 2009). The high impact of fertilization on $\mathrm{N}_{2} \mathrm{O}$ emissions at $\mathrm{CH}-\mathrm{CHA}$ were probably the consequence of generally warm temperatures around $20^{\circ} \mathrm{C}$ in combination with considerably wetter soil conditions in comparison to DE-FEN-I and DE-FEN-E. After some fertilization applications, $\mathrm{N}_{2} \mathrm{O}$ emissions stayed elevated the longest with warm or increasing TS in combination with WFPS quickly decreasing from high to intermediate values, for example on 16 August 2012 at $\mathrm{CH}-\mathrm{CHA}$ (Figure 8). This observation at $\mathrm{CH}-\mathrm{CHA}$ could indicate that $\mathrm{N}_{2} \mathrm{O}$ emissions after fertilizer application were additionally fueled due to decreasing reduction rates of $\mathrm{N}_{2} \mathrm{O}$ to $\mathrm{N}_{2}$ as a consequence of declining WFPS (Wu et al., 2013). However, the exact causes why $\mathrm{N}_{2} \mathrm{O}$ emissions stayed elevated over a given period of time are difficult to determine without additional measurements, such as soil oxygen and substrate availability. For $\mathrm{CH}-\mathrm{CHA}$ during the restoration year 2012, soil water content, soil and air temperature, $\mathrm{N}$ input via fertilization and the net $\mathrm{CO}_{2}$ exchange as a proxy for plant activity were identified as potential drivers for measured $\mathrm{N}_{2} \mathrm{O}$ fluxes (Merbold et al., 2014). The same study found reduced $\mathrm{N}_{2} \mathrm{O}-\mathrm{N}$ EFs during time periods of high productivity or vice versa, suggesting a fast turnover of mineral $\mathrm{N}$ as possible explanation for this observation. However, in this study we were not able to replicate this finding at the annual timescale, as the relationship between net $\mathrm{CO}_{2}$ flux and $\mathrm{N}_{2} \mathrm{O}-\mathrm{N}$ EFs across sites was generally low (data not shown). With the average $\mathrm{N}_{2} \mathrm{O}-\mathrm{N}$ EF across sites in this study being clearly higher than the IPCC Tier 1 EF of $1 \%$ and given the high variability of $\mathrm{N}_{2} \mathrm{O}-\mathrm{N}$ EFs across site-years, more direct long-term measurements are needed to improve and develop sophisticated Tier 2 and Tier 3 EFs for their application at the national scale (IPCC, 2006; Table 6).

This article is protected by copyright. All rights reserved. 
Emission peaks after slurry application were also observed for $\mathrm{CH}_{4}$ and supported earlier findings (e.g. Mori \& Hojito, 2015). However, at DE-FEN-I and DE-FEN-E, $\mathrm{CH}_{4}$ emissions decreased more rapidly to pre-fertilization levels than $\mathrm{N}_{2} \mathrm{O}$ fluxes, suggesting that large amounts of $\mathrm{CH}_{4}$ were released from the slurry itself as opposed to being produced in the soil (Chadwick et al., 2000). In contrast, elevated $\mathrm{CH}_{4}$ emissions at $\mathrm{CH}-\mathrm{CHA}$ after fertilization suggested that small amounts of $\mathrm{CH}_{4}$ were produced in the soil, possibly from organic matter supplied in the slurry, i.e. through the microbial degradation of volatile fatty acids (Sherlock et al., 2002). Furthermore, $\mathrm{CH}_{4}$ oxidation by soil microorganisms was possibly reduced due to elevated $\mathrm{NH}_{4}{ }^{+}$soil concentrations following $\mathrm{N}$ fertilizer applications inhibiting the $\mathrm{CH}_{4}$ oxidation capacity, effectively increasing emissions from the soil (Bodelier \& Laanbroek, 2004). The different emission patterns at $\mathrm{CH}-\mathrm{CHA}$ and DE-FEN-I/DE-FEN-E after fertilizer application are probably due to the respective measurement methods at the sites (Figure 8). Eddy covariance fluxes at $\mathrm{CH}$ CHA are based on an integral signal calculated from high-frequency samples from the whole footprint, comprising both hot spots of high $\mathrm{CH}_{4}$ emissions but also smaller areas of $\mathrm{CH}_{4}$ uptake (Baldocchi et al., 2012). In comparison, chamber measurements at DE-FEN-I and DE-FEN-E represent the exchange over a much smaller area of the grassland, resulting in a more immediate response of the measured signal to fertilizer application in the chambers. Due to this small-scale variability being an integral component of the EC method, fluxes are probably dampened and lower than what would be expected from laboratory or chamber experiments.

At all sites presented in this manuscript, the $\mathrm{CO}_{2}$ flux was the predominant component of the annual GHG budget (Table 4). Our observation that $\mathrm{N}_{2} \mathrm{O}$ and $\mathrm{CH}_{4}$ emissions in terms of $\mathrm{CO}_{2^{-}}$ equivalents offset $21 \pm 6 \%$ of concurrent $\mathrm{CO}_{2}$ uptake is similar to the $18 \%$ reported for European grasslands (Schulze et al., 2009). Even at the heavily grazed site FR-LAQ-I, which was

This article is protected by copyright. All rights reserved. 
characterized by high ruminant $\mathrm{CH}_{4}$ emissions by grazing animals in the EC flux footprint, the grassland was a clear GHG sink (Table 4), supporting earlier observations (Chang et al., 2015). Still, high $\mathrm{CH}_{4}$ emissions at FR-LAQ-I highlighted the need to consider grazing cattle during the evaluation of grassland GHG budgets (e.g., Martin et al., 2010).

We found that year-round GHG measurements are necessary for unbiased GHG budget calculations, mainly due to relevant $\mathrm{N}_{2} \mathrm{O}$ and $\mathrm{CH}_{4}$ flux contributions during spring and winter (Figure 2). Spring $\mathrm{N}_{2} \mathrm{O}$ emissions were most likely dominated either by freeze-thaw emission bursts or high soil moisture conditions after snowmelt (Risk et al., 2013), winter $\mathrm{N}_{2} \mathrm{O}$ production can still occur at low temperatures in frozen soil (Teepe et al., 2001; Zhu et al., 2005; Wertz et al., 2013). For $\mathrm{CH}_{4}$, we assume that seasonal fluxes were mainly driven by the presence or absence of anaerobic $\mathrm{CH}_{4}$-producing microsites in the soil, the application of slurry as fertilizer, as well as temperature (Chadwick et al., 2000; Treat et al., 2014). The role of snow accumulation during winter on observed $\mathrm{CH}_{4}$ emissions needs further investigation (Blanc-Betes et al., 2016).

Direct long-term measurements at site level are of highest importance to quantify the annual GHG exchange. With $\mathrm{N}_{2} \mathrm{O}$ and $\mathrm{CH}_{4}$ flux gap-filling being a source of uncertainty, continuous GHG measurements at high temporal resolution are crucial for reliable GHG budget estimates (Mishurov \& Kiely, 2011; Barton et al., 2015). In this study, the availability of high-resolution data from AC and EC measurements facilitated the application of advanced statistical methods, e.g. the quantification of fertilization impacts on GHG fluxes (Figure 8, Figure 9). For future studies, we recommend simultaneous chamber and EC measurements in the same flux footprint to investigate potential biases of the different methods (Eugster \& Merbold, 2015). Reducing the uncertainty in quantifying $\mathrm{N}_{2} \mathrm{O}$ and $\mathrm{CH}_{4}$ budgets at the site level is ideally done using a multi-step approach and comprises (1) spatial snapshot measurements of small areas for the identification of

This article is protected by copyright. All rights reserved. 
emission hot spots in order to understand footprint source/sink heterogeneity, (2) capturing temporal high fluxes, and (3) identifying environmental conditions that indicate enhanced GHG source/sink activity, i.e. sweet spots. While (1) is best achieved via chamber measurements using multiple plots (Skiba et al., 2009; Cowan et al., 2015), (2) and (3) are best investigated via longterm automatic chamber or eddy covariance measurements at high temporal resolution, thus covering a wide range of environmental conditions while considering spatial information from (1) during data interpretation. For grazed sites, knowledge of animal movements and distribution of manure pats in the flux footprint have to be considered for in depth analyses of GHG source/sink behavior (Felber et al., 2015). This is of special importance for the EC method, by which smallscale emission and deposition hot spots are integrated spatially (Baldocchi et al., 2012). In addition, future research should also focus on the development and improvement of meaningful land use indices that consider specific management strategies at the site-level and aggregate available site information into objective categories. While we are aware of existing indices for land use intensity (e.g., Blüthgen et al., 2012), we refrained from applying them due to various simplifications that lead to indices lacking representativity for sites included in this study. The availability of representative, objective land use indices would allow accurate classifications of managed grasslands into meaningful categories, and thus improved statistical analyses of in-situ data across sites. Generally, it is challenging to attribute annual budgets to specific management strategies. The main reason for this is the finding that site-specific GHG fluxes vary considerably between years despite similar management (Table 4). This observation mandates the inclusion of extended datasets in GHG analyses that comprise comprehensive soil and management information, but also the application of advanced statistical methods (e.g., Dengel et al., 2013).

This article is protected by copyright. All rights reserved. 
Central European grassland sites in this study were characterized by site-specific management strategies that reflected the wide range of site characteristics and exemplified the complexity of managed grassland ecosystems in geographical proximity. The $\mathrm{CO}_{2}$ sink strength as the predominant component of the annual GHG budget highlighted the need to conduct $\mathrm{CO}_{2}$ flux measurements at the site-level. However, the impact of $\mathrm{N}_{2} \mathrm{O}$ and $\mathrm{CH}_{4}$ on the annual NGB of the grassland is substantial at many sites. Therefore, due to the absence of robust relationships between $\mathrm{N}_{2} \mathrm{O}$ and $\mathrm{CH}_{4}$ fluxes and environmental drivers, long-term in-situ measurements are crucial in reliably assessing the full annual NGB of specific grasslands. This is especially important during extreme management events such as grassland restoration that includes ploughing, which have the potential to change an otherwise strong annual GHG sink to a source.

\section{Acknowledgements}

We greatly acknowledge funding received from the following sources. The Swiss sites were funded by the European Union Seventh Framework Programme (FP7, 2007-2013) under grant agreement no. 244122 (GHG-Europe), the Swiss National Science Foundation under grants FasMeF (200021_129866) and FACCE-JPI project Models4Pastures (40FA40_154245) as well as the COST Action ES0804 - ABBA. This study was financially supported by the Austrian National Science Fund (FWF) under contract P23267-B16, the Tyrolean Science Fund under contract Uni-404/1083, the EU framework 7 project GHG Europe (EU contract no. 244122) and the Austrian Federal Ministry of Science, Research and Economy through an infrastructure grant. Infrastructure and work at the German sites were funded by the Helmholtz Association (01LL0801B) and the Federal Ministry of Education and Research (BMBF) via the BonaRes project SUSALPS (031B0027A). In addition, we are grateful for the help of all Grassland Sciences group members at ETH Zurich who participated in the intensive observation campaigns

This article is protected by copyright. All rights reserved. 
at CH-CHA, CH-FRU and CH-AWS in 2010 and 2011, as well as the technical team based in Zurich, Thomas Baur, Philip Meier and Peter Plüss.

\section{References}

Allard V, Soussana J-FF, Falcimagne R et al. (2007) The role of grazing management for the net biome productivity and greenhouse gas budget $\left(\mathrm{CO}_{2}, \mathrm{~N}_{2} \mathrm{O}\right.$ and $\left.\mathrm{CH}_{4}\right)$ of semi-natural grassland. Agriculture, Ecosystems \& Environment, 121, 47-58.

Bahn M, Rodeghiero M, Anderson-Dunn M et al. (2008) Soil respiration in European grasslands in relation to climate and assimilate supply. Ecosystems, 11, 1352-1367.

Baldocchi DD, Hincks BB, Meyers TP (1988) Measuring biosphere-atmosphere exchanges of biologically related gases with micrometeorological methods. Ecology, 69, 1331-1340.

Baldocchi D, Detto M, Sonnentag O, Verfaillie J, Teh YA, Silver W, Kelly NM (2012) The challenges of measuring methane fluxes and concentrations over a peatland pasture. Agricultural and Forest Meteorology, 153, 177-187.

Ball BC (2013) Soil structure and greenhouse gas emissions: a synthesis of 20 years of experimentation. European Journal of Soil Science, 64, 357-373.

Barnard R, Leadley PW, Hungate BA (2005) Global change, nitrification, and denitrification: A review. Global Biogeochemical Cycles, 19, 1-13.

Barnosky AD (2008) Colloquium paper: Megafauna biomass tradeoff as a driver of Quaternary and future extinctions. Proceedings of the National Academy of Sciences of the United States of America, 105 Suppl, 11543-11548.

Barton L, Wolf B, Rowlings D et al. (2015) Sampling frequency affects estimates of annual nitrous oxide fluxes. Scientific Reports, 5, 15912.

This article is protected by copyright. All rights reserved. 
Beyer C, Liebersbach H, Höper H (2015) Multiyear greenhouse gas flux measurements on a temperate fen soil used for cropland or grassland. Journal of Plant Nutrition and Soil Science, 178, 99-111.

Bhandral R, Bolan N. SNS, Saggar S (2010) Nitrous oxide emission from farm dairy effluent application in grazed grassland. Revista de la ciencia del suelo y nutrición vegetal, 10, 2234.

Bijoor NS, Czimczik CI, Pataki DE, Billings SA (2008) Effects of temperature and fertilization on nitrogen cycling and community composition of an urban lawn. Global Change Biology, 14, 2119-2131.

Blanc-Betes E, Welker JM, Sturchio NC, Chanton JP, Gonzalez-Meler MA (2016) Winter precipitation and snow accumulation drive the methane sink or source strength of Arctic tussock tundra. Global Change Biology, 22, 2818-2833.

Blüthgen N, Dormann CF, Prati D et al. (2012) A quantitative index of land-use intensity in grasslands: Integrating mowing, grazing and fertilization. Basic and Applied Ecology, 13, 207-220.

Bodelier PL., Laanbroek HJ (2004) Nitrogen as a regulatory factor of methane oxidation in soils and sediments. FEMS Microbiology Ecology, 47, 265-277.

Butterbach-Bahl K, Baggs EM, Dannenmann M, Kiese R, Zechmeister-Boltenstern S (2013) Nitrous oxide emissions from soils: how well do we understand the processes and their controls? Philosophical transactions of the Royal Society of London. Series B, Biological sciences, 368, 20130122.

Chadwick DR, Pain BF, Brookman SKE (2000) Nitrous Oxide and Methane Emissions following

This article is protected by copyright. All rights reserved. 
Application of Animal Manures to Grassland. Journal of Environment Quality, 29, 277-287.

Chang J, Ciais P, Viovy N, Vuichard N, Sultan B, Soussana J-FF (2015) The greenhouse gas balance of European grasslands. Global Change Biology, 21, 3748-3761.

Chapuis-Lardy L, Wrage N, Metay A, Chotte JL, Bernoux M (2007) Soils, a sink for N2O? A review. Global Change Biology, 13, 1-17.

Chiavegato MB, Powers WJ, Carmichael D, Rowntree JE (2015) Pasture-derived greenhouse gas emissions in cow-calf production systems. Journal of Animal Science, 93, 1350.

Clough TJ, Sherlock RR, Rolston DE (2005) A review of the movement and fate of $\mathrm{N}_{2} \mathrm{O}$ in the subsoil. Nutrient Cycling in Agroecosystems, 72, 3-11.

Conrad R (2009) The global methane cycle: recent advances in understanding the microbial processes involved. Environmental Microbiology Reports, 1, 285-292.

Cowan NJ, Norman P, Famulari D, Levy PE, Reay DS, Skiba UM (2015) Spatial variability and hotspots of soil $\mathrm{N}_{2} \mathrm{O}$ fluxes from intensively grazed grassland. Biogeosciences, 12, 15851596.

Davidson EA (2009) The contribution of manure and fertilizer nitrogen to atmospheric nitrous oxide since 1860. Nature Geoscience, 2, 659-662.

Dengel S, Levy PE, Grace J, Jones SK, Skiba UM (2011) Methane emissions from sheep pasture, measured with an open-path eddy covariance system. Global Change Biology, 17, 35243533.

Dengel S, Zona D, Sachs T et al. (2013) Testing the applicability of neural networks as a gapfilling method using $\mathrm{CH}_{4}$ flux data from high latitude wetlands. Biogeosciences, 10, 81858200.

This article is protected by copyright. All rights reserved. 
Dijkstra FA, Morgan JA, Follett RF, LeCain DR (2013) Climate change reduces the net sink of $\mathrm{CH}_{4}$ and $\mathrm{N}_{2} \mathrm{O}$ in a semiarid grassland. Global Change Biology, 19, 1816-1826.

Dumortier P, Aubinet M, Beckers Y et al. (2017) Methane balance of an intensively grazed pasture and estimation of the enteric methane emissions from cattle. Agricultural and Forest Meteorology, 232, 527-535.

Dunfield PF (2007) The soil methane sink. In: Greenhouse gas sinks (eds Reay DS, Hewitt CN, Smith KA, Grace J), pp. 152-170. CABI, Wallingford.

Dutaur L, Verchot L V. (2007) A global inventory of the soil $\mathrm{CH}_{4}$ sink. Global Biogeochemical Cycles, 21, GB4013.

Eugster W, Merbold L (2015) Eddy covariance for quantifying trace gas fluxes from soils. Soil, 1, $187-205$.

FAOSTAT (2017) Food and Agriculture Organization Corporate Statistical Database.

Felber R, Neftel A, Ammann C, Münger A, Neftel A, Ammann C (2015) Eddy covariance methane flux measurements over a grazed pasture: effect of cows as moving point sources. Biogeosciences, 12, 3925-3940.

Firestone MK, Davidson EA (1989) Microbiologial basis of $\mathrm{NO}$ and $\mathrm{N}_{2} \mathrm{O}$ production and consumption in soil. In: Exchange of trace gases between terrestrial ecosystems and the atmosphere (eds Andreae MO, Schimel DS), pp. 7-21. John Wiley \& Sons, New York.

Fowler D, Pilegaard K, Sutton MA et al. (2009) Atmospheric composition change: EcosystemsAtmosphere interactions. Atmospheric Environment, 43, 5193-5267.

Frankenberg C, Aben I, Bergamaschi P et al. (2011) Global column-averaged methane mixing ratios from 2003 to 2009 as derived from SCIAMACHY: Trends and variability. Journal of 
Geophysical Research: Atmospheres, 116, 1-12.

Galloway JN, Aber JD, Erisman JW et al. (2003) The nitrogen cascade. BioScience, 53, 341.

Gelfand I, Zenone T, Jasrotia P, Chen J, Hamilton SK, Robertson GP (2011) Carbon debt of Conservation Reserve Program (CRP) grasslands converted to bioenergy production. Proceedings of the National Academy of Sciences, 108, 13864-13869.

Gilmanov TG, Soussana JF, Aires L et al. (2007) Partitioning European grassland net ecosystem $\mathrm{CO}_{2}$ exchange into gross primary productivity and ecosystem respiration using light response function analysis. Agriculture, Ecosystems \& Environment, 121, 93-120.

Gilmanov TG, Aires L, Barcza Z et al. (2010) Productivity, respiration, and light-response parameters of world grassland and agroecosystems derived from flux-tower measurements. Rangeland Ecology \& Management, 63, 16-39.

Gomez-Casanovas N, Hudiburg TW, Bernacchi CJ, Parton WJ, DeLucia EH (2016) Nitrogen deposition and greenhouse gas emissions from grasslands: uncertainties and future directions. Global Change Biology, 22, 1348-1360.

Hernandez ME, Marín-Muñiz JL, Moreno-Casasola P, Vázquez V (2014) Comparing soil carbon pools and carbon gas fluxes in coastal forested wetlands and flooded grasslands in Veracruz, Mexico. International Journal of Biodiversity Science, Ecosystem Services \& Management, $1-12$.

Hiller RV, Bretscher D, DelSontro T et al. (2014) Anthropogenic and natural methane fluxes in Switzerland synthesized within a spatially explicit inventory. Biogeosciences, 11, 19411959.

Hofmann K, Farbmacher S, Illmer P (2016) Methane flux in montane and subalpine soils of the

This article is protected by copyright. All rights reserved. 
Central and Northern Alps. Geoderma, 281, 83-89.

Holtan-Hartwig L, Dörsch P, Bakken LR (2002) Low temperature control of soil denitrifying communities: Kinetics of $\mathrm{N}_{2} \mathrm{O}$ production and reduction. Soil Biology and Biochemistry, 34, 1797-1806.

Hörtnagl L, Wohlfahrt G (2014) Methane and nitrous oxide exchange over a managed hay meadow. Biogeosciences, 11, 7219-7236.

$\mathrm{Hu}$ Y, Chang X, Lin X et al. (2010) Effects of warming and grazing on $\mathrm{N}_{2} \mathrm{O}$ fluxes in an alpine meadow ecosystem on the Tibetan plateau. Soil Biology and Biochemistry, 42, 944-952.

Huber R, Rigling A, Bebi P et al. (2013) Sustainable Land Use in Mountain Regions Under Global Change: Synthesis Across Scales and Disciplines. Ecology and Society, 18, art36.

Huber R, Briner S, Bugmann H et al. (2014) Inter- and transdisciplinary perspective on the integration of ecological processes into ecosystem services analysis in a mountain region. Ecological Processes, 3, 9.

Hunter JD (2007) Matplotlib: A 2D Graphics Environment. Computing in Science \& Engineering, 9, 90-95.

Imer D, Merbold L, Eugster W, Buchmann N (2013) Temporal and spatial variations of soil $\mathrm{CO}_{2}$, $\mathrm{CH}_{4}$ and $\mathrm{N}_{2} \mathrm{O}$ fluxes at three differently managed grasslands. Biogeosciences, 10, 59315945.

IPCC (2006) 2006 IPCC guidelines for national greenhouse gas inventories, Volume 4: Agriculture, forestry and other land use. In: IPCC national greenhouse gas inventories programme (eds Eggleston HS, Buendia L, Miwa K, Ngara T, Tanabe K). IGES, Japan, Hayama, Japan.

This article is protected by copyright. All rights reserved. 
IPCC (2013) Climate Change 2013: The Physical Science Basis. Contribution of Working Group I to the Fifth Assessment Report of the Intergovernmental Panel on Climate Change (eds Stocker TF, Qin D, Plattner G-K, Tignor M, Allen SK, Boschung J, Nauels A, Xia Y, Bex V, Midgley PM). Cambridge University Press, Cambridge, 1535pp pp.

Jones SK, Famulari D, Di Marco CF, Nemitz E, Skiba UM, Rees RM, Sutton MA (2011) Nitrous oxide emissions from managed grassland: A comparison of eddy covariance and static chamber measurements. Atmospheric Measurement Techniques, 4, 2179-2194.

Jones CM, Spor A, Brennan FP et al. (2014) Recently identified microbial guild mediates soil $\mathrm{N}_{2} \mathrm{O}$ sink capacity. Nature Climate Change, 4, 801-805.

Kim Y, Tanaka N (2015) Fluxes of $\mathrm{CO}_{2}, \mathrm{~N}_{2} \mathrm{O}$ and $\mathrm{CH}_{4}$ by ${ }^{222} \mathrm{Rn}$ and chamber methods in coldtemperate grassland soil, northern Japan. Soil Science and Plant Nutrition, 61, 88-97.

Klumpp K, Bloor JMG, Ambus P, Soussana JF (2011) Effects of clover density on $\mathrm{N}_{2} \mathrm{O}$ emissions and plant-soil $\mathrm{N}$ transfers in a fertilised upland pasture. Plant and Soil, 343, 97107.

Kroon PS, Schrier-Uijl AP, Hensen A, Veenendaal EM, Jonker HJJ (2010) Annual balances of $\mathrm{CH}_{4}$ and $\mathrm{N}_{2} \mathrm{O}$ from a managed fen meadow using eddy covariance flux measurements. European Journal of Soil Science, 61, 773-784.

Lal R (2010) Managing Soils and Ecosystems for Mitigating Anthropogenic Carbon Emissions and Advancing Global Food Security. BioScience, 60, 708-721.

Laville P, Lehuger S, Loubet B, Chaumartin F, Cellier P (2011) Effect of management, climate and soil conditions on $\mathrm{N}_{2} \mathrm{O}$ and $\mathrm{NO}$ emissions from an arable crop rotation using high temporal resolution measurements. Agricultural and Forest Meteorology, 151, 228-240.

This article is protected by copyright. All rights reserved. 
Peichl M, Sonnentag O, Wohlfahrt G et al. (2013) Convergence of potential net ecosystem production among contrasting $\mathrm{C}_{3}$ grasslands (ed Hooper D). Ecology Letters, 16, 502-512.

Li C, Frolking S, Frolking TA, Changsheng L, Frolking S, Frolking TA (1992) A model of nitrous oxide evolution from soil driven by rainfall events: 2. Model applications. Journal of Geophysical Research, 97, 9759-9776.

Li Y, Dong S, Liu S et al. (2015) Seasonal changes of $\mathrm{CO}_{2}, \mathrm{CH}_{4}$ and $\mathrm{N}_{2} \mathrm{O}$ fluxes in different types of alpine grassland in the Qinghai-Tibetan Plateau of China. Soil Biology and Biochemistry, 80, 306-314.

Liu L, Greaver TL (2009) A review of nitrogen enrichment effects on three biogenic GHGs: The $\mathrm{CO}_{2}$ sink may be largely offset by stimulated $\mathrm{N}_{2} \mathrm{O}$ and $\mathrm{CH}_{4}$ emission. Ecology Letters, 12 , 1103-1117.

Lu H (2016) The influence of land management and simulated climate change on $\mathrm{N}_{2} \mathrm{O}$ and $\mathrm{CH}_{4}$ exchange of montane grassland soils. PhD thesis, University of Freiburg, $126 \mathrm{pp}$.

Luo GJ, Kiese R, Wolf B, Butterbach-Bahl K (2013) Effects of soil temperature and moisture on methane uptake and nitrous oxide emissions across three different ecosystem types. Biogeosciences, 10, 3205-3219.

Lüscher A, Mueller-Harvey I, Soussana JF, Rees RM, Peyraud JL (2014) Potential of legumebased grassland-livestock systems in Europe: a review. Grass and Forage Science, 69, 206228.

Luyssaert S, Jammet M, Stoy PC et al. (2014) Land management and land-cover change have impacts of similar magnitude on surface temperature. Nature Climate Change, 4, 389393.

This article is protected by copyright. All rights reserved. 
Martin C, Morgavi DP, Doreau M (2010) Methane mitigation in ruminants: from microbe to the farm scale. Animal, 4, 351-365.

McKinney W (2010) Data Structures for Statistical Computing in Python (eds van der Walt S, Millman J). Proceedings of the 9th Python in Science Conference, 1697900, 51-56.

Le Mer J, Roger P (2001) Production, oxidation, emission and consumption of methane by soils: A review. European Journal of Soil Biology, 37, 25-50.

Merbold L, Steinlin C, Hagedorn F (2013) Winter greenhouse gas fluxes $\left(\mathrm{CO}_{2}, \mathrm{CH}_{4}\right.$ and $\left.\mathrm{N}_{2} \mathrm{O}\right)$ from a subalpine grassland. Biogeosciences, 10, 3185-3203.

Merbold L, Eugster W, Stieger J, Zahniser M, Nelson D, Buchmann N (2014) Greenhouse gas budget $\left(\mathrm{CO}_{2}, \mathrm{CH}_{4}\right.$ and $\left.\mathrm{N}_{2} \mathrm{O}\right)$ of intensively managed grassland following restoration. Global Change Biology, 20, 1913-1928.

Mishurov M, Kiely G (2010) Nitrous oxide flux dynamics of grassland undergoing afforestation. Agriculture, Ecosystems and Environment, 139, 59-65.

Mishurov M, Kiely G (2011) Gap-filling techniques for the annual sums of nitrous oxide fluxes. Agricultural and Forest Meteorology, 151, 1763-1767.

Mori A, Hojito M (2015) Effect of dairy manure type and supplemental synthetic fertilizer on methane and nitrous oxide emissions from a grassland in Nasu, Japan. Soil Science and Plant Nutrition, 61, 347-358.

Neftel A, Ammann C, Fischer $\mathrm{C}$ et al. (2010) $\mathrm{N}_{2} \mathrm{O}$ exchange over managed grassland: Application of a quantum cascade laser spectrometer for micrometeorological flux measurements. Agricultural and Forest Meteorology, 150, 775-785.

Paustian K, Lehmann J, Ogle S, Reay D, Robertson GP, Smith P (2016) Climate-smart soils.

This article is protected by copyright. All rights reserved. 
Nature, 532, 49-57.

Price SJ, Kelliher FM, Sherlock RR, Tate KR, Condron LM (2004) Environmental and chemical factors regulating methane oxidation in a New Zealand forest soil. Australian Journal of Soil Research, 42, 767.

Reay DS, Davidson EA, Smith KA, Smith P, Melillo JM, Dentener F, Crutzen PJ (2012) Global agriculture and nitrous oxide emissions. Nature Climate Change, 2, 410-416.

Reichstein M, Falge E, Baldocchi D et al. (2005) On the separation of net ecosystem exchange into assimilation and ecosystem respiration: review and improved algorithm. Global Change Biology, 11, 1424-1439.

Risk N, Snider D, Wagner-Riddle C (2013) Mechanisms leading to enhanced soil nitrous oxide fluxes induced by freeze-thaw cycles. Canadian Journal of Soil Science, 93, 401-414.

Rowlings DW, Grace PR, Scheer C, Liu S (2015) Rainfall variability drives interannual variation in $\mathrm{N}_{2} \mathrm{O}$ emissions from a humid, subtropical pasture. Science of The Total Environment, 512-513, 8-18.

Saggar S, Jha N, Deslippe J et al. (2013) Denitrification and $\mathrm{N}_{2} \mathrm{O}: \mathrm{N}_{2}$ production in temperate grasslands: Processes, measurements, modelling and mitigating negative impacts. Science of The Total Environment, 465, 173-195.

Schlesinger WH (2013) An estimate of the global sink for nitrous oxide in soils. Global Change Biology, 19, 2929-2931.

Schmitt M, Bahn M, Wohlfahrt G, Tappeiner U, Cernusca A (2010) Land use affects the net ecosystem $\mathrm{CO}_{2}$ exchange and its components in mountain grasslands. Biogeosciences, 7, 2297-2309.

This article is protected by copyright. All rights reserved. 
Schulze ED, Luyssaert S, Ciais P et al. (2009) Importance of methane and nitrous oxide for Europe's terrestrial greenhouse-gas balance. Nature Geoscience, 2, 842-850.

Seabold S, Perktold J (2010) Statsmodels: econometric and statistical modeling with Python. Proceedings of the 9th Python in Science Conference, 57-61.

Sherlock RR, Sommer SG, Khan RZ et al. (2002) Ammonia, methane, and nitrous oxide emission from pig slurry applied to a pasture in new zealand. Journal of Environment Quality, 31, 1491-1501.

Skiba U, Drewer J, Tang YS et al. (2009) Biosphere-atmosphere exchange of reactive nitrogen and greenhouse gases at the NitroEurope core flux measurement sites: Measurement strategy and first data sets. Agriculture, Ecosystems and Environment, 133, 139-149.

Soussana JF, Allard V, Pilegaard K et al. (2007) Full accounting of the greenhouse gas $\left(\mathrm{CO}_{2}\right.$, $\mathrm{N}_{2} \mathrm{O}, \mathrm{CH}_{4}$ ) budget of nine European grassland sites. Agriculture, Ecosystems and Environment, 121, 121-134.

Syakila A, Kroeze C (2011) The global nitrous oxide budget revisited. Greenhouse Gas Measurement and Management, 1, 17-26.

Tate KR (2015) Soil methane oxidation and land-use change - from process to mitigation. Soil Biology and Biochemistry, 80, 260-272.

Teepe R, Brumme R, Beese F (2001) Nitrous oxide emissions from soil during freezing and thawing periods. Soil Biology and Biochemistry, 33, 1269-1275.

Teh YA, Silver WL, Sonnentag O, Detto M, Kelly M, Baldocchi DD (2011) Large greenhouse gas emissions from a temperate peatland pasture. Ecosystems, 14, 311-325.

Treat CC, Wollheim WM, Varner RK, Grandy AS, Talbot J, Frolking S (2014) Temperature and

This article is protected by copyright. All rights reserved. 
peat type control $\mathrm{CO}_{2}$ and $\mathrm{CH}_{4}$ production in Alaskan permafrost peats. Global Change Biology, 20, 2674-2686.

Tubiello FN, Salvatore M, Ferrara AF et al. (2015) The Contribution of Agriculture, Forestry and other Land Use activities to Global Warming, 1990-2012. Global Change Biology, 21, $2655-2660$.

UNFCCC (2015) Adoption of the Paris Agreement.

Unteregelsbacher S, Gasche R, Lipp L et al. (2013) Increased methane uptake but unchanged nitrous oxide flux in montane grasslands under simulated climate change conditions. European Journal of Soil Science, 64, 586-596.

Van Der Walt S, Colbert SC, Varoquaux G (2011) The NumPy array: A structure for efficient numerical computation. Computing in Science and Engineering, 13, 22-30.

Wang X, Zhang Y, Huang D, Li Z, Zhang X (2015) Methane uptake and emissions in a typical steppe grazing system during the grazing season. Atmospheric Environment, 105, 14-21.

Wei D, Xu-Ri, Tenzin-Tarchen et al. (2015) Considerable methane uptake by alpine grasslands despite the cold climate: In situ measurements on the central Tibetan Plateau, 2008-2013. Global Change Biology, 21, 777-788.

Wertz S, Goyer C, Zebarth BJ, Burton DL, Tatti E, Chantigny MH, Filion M (2013) Effects of temperatures near the freezing point on $\mathrm{N}_{2} \mathrm{O}$ emissions, denitrification and on the abundance and structure of nitrifying and denitrifying soil communities. FEMS Microbiology Ecology, 83, 242-254.

Whalen SC (2005) Biogeochemistry of methane exchange between natural wetlands and the atmosphere. Environmental Engineering Science, 22, 73-94.

This article is protected by copyright. All rights reserved. 
Wohlfahrt G, Anderson-Dunn M, Bahn M et al. (2008a) Biotic, abiotic, and management controls on the net ecosystem $\mathrm{CO}_{2}$ exchange of European mountain grassland ecosystems. Ecosystems, 11, 1338-1351.

Wohlfahrt G, Hammerle A, Haslwanter A, Bahn M, Tappeiner U, Cernusca A (2008b) Seasonal and inter-annual variability of the net ecosystem $\mathrm{CO}_{2}$ exchange of a temperate mountain grassland: Effects of weather and management. Journal of Geophysical Research: Atmospheres, 113, 1-14.

Wolf B, Zheng X, Brüggemann N et al. (2010) Grazing-induced reduction of natural nitrous oxide release from continental steppe. Nature, 464, 881-884.

Wu D, Dong W, Oenema O, Wang Y, Trebs I, Hu C (2013) $\mathrm{N}_{2} \mathrm{O}$ consumption by low-nitrogen soil and its regulation by water and oxygen. Soil Biology and Biochemistry, 60, 165-172.

Yvon-Durocher G, Allen AP, Bastviken D et al. (2014) Methane fluxes show consistent temperature dependence across microbial to ecosystem scales. Nature, 507, 488-91.

Zeeman MJ, Mauder M, Steinbrecher R, Heidbach K, Eckart E, Schmid HP (2017) Reduced snow cover affects productivity of upland temperate grasslands. Agricultural and Forest Meteorology, 232, 514-526.

Zhu R, Sun L, Ding W (2005) Nitrous oxide emissions from tundra soil and snowpack in the maritime Antarctic. Chemosphere, 59, 1667-1675.

This article is protected by copyright. All rights reserved. 


\section{Tables}

Table 1 Basic information for each research site included in this study.

\begin{tabular}{|c|c|c|c|c|c|}
\hline Site & CH-AWS & AT-STU-P & AT-STU-M & FR-LAQ-I & FR-LAQ-E \\
\hline Location & Alp Weissenstein, Switzerland & Stubai Valley, Austria & Stubai Valley, Austria & Laqueuille, France & Laqueuille, France \\
\hline Latitude & $46^{\circ} 34^{\prime} 59^{\prime \prime} \mathrm{N}$ & $47^{\circ} 12^{\prime} 87^{\prime \prime} \mathrm{N}$ & $47^{\circ} 12^{\prime} 88^{\prime \prime} \mathrm{N}$ & $45^{\circ} 38^{\prime} 00^{\prime \prime} \mathrm{N}$ & $45^{\circ} 38^{\prime} 00^{\prime \prime} \mathrm{N}$ \\
\hline Longitude & $9^{\circ} 47^{\prime} 25^{\prime \prime} \mathrm{E}$ & $11^{\circ} 30^{\prime} 33^{\prime \prime} \mathrm{E}$ & $11^{\circ} 30^{\prime} 58^{\prime \prime} \mathrm{E}$ & $2^{\circ} 44^{\prime} 00^{\prime \prime} \mathrm{E}$ & $2^{\circ} 44^{\prime} 00^{\prime \prime} \mathrm{E}$ \\
\hline Elevation (m) & 1978 & 1870 & 1820 & 1040 & 1040 \\
\hline Management & extensive & extensive & extensive & intensive & extensive \\
\hline MAT $\left({ }^{\circ} \mathbf{C}\right)$ & -1.4 & 3.0 & 3.0 & 7.0 & 7.0 \\
\hline $\operatorname{MAP}(\mathbf{m m})$ & 1214 & 1097 & 1097 & 1200 & 1200 \\
\hline Snow cover days & 166 & 124 & 128 & $25-91$ & $25-91$ \\
\hline Grass $(\%)$ & 95 & n.a. & 54 & 69 & 77 \\
\hline Clover (\%) & $<5$ & n.a. & 5 & 11 & 4 \\
\hline 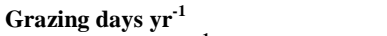 & $<20$ & 120 & 70 & $142-170$ & $142-170$ \\
\hline Grazing animals $\mathrm{d}^{-1}$ & 20 cows & $\sim 7$ cows, 15 sheep & $\sim 7$ cows, 15 sheep & $9-14$ cows & $7-9$ cows \\
\hline Cutting events & 0 & 0 & 1 & 0 & 0 \\
\hline Harvest C / N $\left(\mathrm{kg} \mathrm{ha}^{-1} \mathrm{DW}\right)$ & 0 & 0 & unknown & 0 & 0 \\
\hline Fertilization events & 1 & 1 & 1 & 3 & 0 \\
\hline Organic fertilizer $\mathrm{C} / \mathrm{N}\left(\mathrm{kg} \mathrm{ha}^{-1} \mathrm{yr}^{-1}\right)$ & unknown & $1390 / 70$ (solid manure) & $1390 / 70$ (solid manure) & 0 & 0 \\
\hline Mineral fertilizer $\mathbf{N}\left(\mathrm{kg} \mathrm{ha}^{-1} \mathbf{y r}^{-1}\right)$ & 0 & 0 & 0 & 214 & 0 \\
\hline $\mathrm{CO}_{2} / \mathrm{N}_{2} \mathrm{O} / \mathrm{CH}_{4}$ flux method & $\mathrm{EC} / \mathrm{MC} / \mathrm{MC}$ & None / MC / MC & $\mathrm{MC} / \mathrm{MC} / \mathrm{MC}$ & $\mathrm{EC} / \mathrm{AC} / \mathrm{EC}$ & $\mathrm{EC} / \mathrm{AC} / \mathrm{none}$ \\
\hline $\mathrm{CO}_{2} / \mathrm{N}_{2} \mathrm{O} / \mathrm{CH}_{4}$ measurement days & $339 / 20 / 20$ & $0 / 27 / 26$ & $0 / 51 / 50$ & $1373 / 1123 / 318$ & $863 / 878 / 0$ \\
\hline Chamber plots & 16 & 5 & 5 & 4 & 4 \\
\hline $\mathbf{G F}_{\mathrm{RM}}$ window size (days) & 60 & 60 & 60 & 60 & 60 \\
\hline Reference & Imer et al. (2013) & Schmitt et al. (2010) & Schmitt et al. (2010) & $\begin{array}{l}\text { Klumpp et al. (2011a) } \\
\text { Allard et al.(2007) }\end{array}$ & $\begin{array}{l}\text { Klumpp et al. (2011a) } \\
\text { Allard et al.(2007) }\end{array}$ \\
\hline
\end{tabular}

This article is protected by copyright. All rights reserved. 
Table 1 Continued.

\begin{tabular}{|c|c|c|c|c|}
\hline Site & CH-FRU-I & CH-FRU-E & AT-NEU & DE-GAP \\
\hline Location & Früebüel, Switzerland & Früebüel, Switzerland & Neustift, Austria & $\begin{array}{l}\text { Garmisch-Partenkirchen, } \\
\text { Germany }\end{array}$ \\
\hline Latitude & $47^{\circ} 6^{\prime} 57^{\prime \prime} \mathrm{N}$ & $47^{\circ} 6^{\prime} 57^{\prime \prime} \mathrm{N}$ & $47^{\circ} 07^{\prime} 00^{\prime \prime} \mathrm{N}$ & $47^{\circ} 28^{\prime} 32.12^{\prime \prime} \mathrm{N}$ \\
\hline Longitude & $8^{\circ} 32^{\prime} 16^{\prime \prime} \mathrm{E}$ & $8^{\circ} 32^{\prime} 16^{\prime \prime} \mathrm{E}$ & $11^{\circ} 19^{\prime} 07^{\prime \prime} \mathrm{E}$ & $11^{\circ} 3^{\prime} 44.47^{\prime \prime} \mathrm{E}$ \\
\hline Elevation $(\mathbf{m})$ & 982 & 982 & 970 & 734 \\
\hline Management & intensive & extensive & intensive & extensive \\
\hline MAT $\left({ }^{\circ} \mathbf{C}\right)$ & 6.1 & 6.1 & 6.5 & 6.8 \\
\hline MAP (mm) & 1682 & 1682 & 852 & 1371 \\
\hline Snow cover days & 111 & 111 & $93 / 92$ & $72-91$ \\
\hline Grass $(\%)$ & n.a. & n.a. & $20-40$ & 52 \\
\hline Clover (\%) & $5-25$ & $5-25$ & 5 & 8 \\
\hline Grazing days $\mathbf{y r}^{-1}$ & 29 & 10 & 0 & 0 \\
\hline 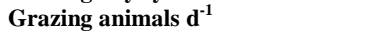 & 54-57 cows & $40-56$ cows & 0 & 0 \\
\hline Cutting events & 1 & 2 & 2010: 3 & 2012: 3 \\
\hline & & & 2011: 3 & 2013: 3 \\
\hline Harvest C / N $\left(\mathrm{kg} \mathrm{ha}^{-1} \mathrm{DW}\right)$ & $1482 / 95$ & $4389 / 280$ & 2010: $3470 / 169$ & 2012: $2940 / 150$ \\
\hline & & & 2011: $3676 / 180$ & 2013: $4507 / 245$ \\
\hline Fertilization events & 3 & 1 & 2010: 1 & 2012: 1 \\
\hline & & & 2011: 1 & 2013: 2 \\
\hline Organic fertilizer $\mathrm{C} / \mathrm{N}\left(\mathrm{kg} \mathrm{ha}^{-1} \mathrm{yr}^{-1}\right)$ & $939 / 159$ (slurry) & $495 / 33$ (slurry) & $2730 / 341$ (solid manure \& slurry) & $\begin{array}{l}\text { 2012: } 390 \text { / } 61 \text { (slurry) } \\
\text { 2013: } 1071 \text { / 122 (slurry) }\end{array}$ \\
\hline Mineral fertilizer $N\left(\mathrm{~kg} \mathrm{ha}^{-1} \mathbf{y r}^{-1}\right)$ & 0 & 0 & 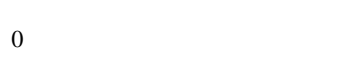 & $\begin{array}{l}\text { 2013: } 1071 \text { / } 122 \text { (slurry) } \\
0\end{array}$ \\
\hline $\mathrm{CO}_{2} / \mathrm{N}_{2} \mathrm{O} / \mathrm{CH}_{4}$ flux method & $\mathrm{EC} / \mathrm{MC} / \mathrm{MC}$ & $\mathrm{EC} / \mathrm{MC} / \mathrm{MC}$ & $\mathrm{EC} / \mathrm{EC} / \mathrm{EC}$ & all: MC \\
\hline $\mathrm{CO}_{2} / \mathrm{N}_{2} \mathrm{O} / \mathrm{CH}_{4}$ measurement days & $570 / 35 / 34$ & $571 / 35 / 35$ & $769 / 598 / 596$ & $0 / 92 / 93$ \\
\hline Chamber plots & 6 & 10 & 0 & 3 \\
\hline $\mathbf{G F}_{\mathrm{RM}}$ window size (days) & 15 & 60 & 15 & 120 \\
\hline Reference & Imer et al. (2013) & Imer et al. (2013) & $\begin{array}{l}\text { Hörtnagl \& Wohlfahrt (2014) } \\
\text { Wohlfahrt et al. (2008) }\end{array}$ & Lu, (2016) \\
\hline
\end{tabular}

This article is protected by copyright. All rights reserved. 
Table 1 Continued.

\begin{tabular}{|c|c|c|c|c|c|}
\hline Site & DE-FEN-III & DE-FEN-EI & CH-CHA-I1 & CH-CHA-I2 $\dagger$ & CH-CHA $\$$ \\
\hline Location & Fendt, Germany & Fendt, Germany & Chamau, Switzerland & Chamau, Switzerland & Chamau, Switzerland \\
\hline Latitude & $47^{\circ} 82^{\prime} \mathrm{N}$ & $47^{\circ} 82^{\prime} \mathrm{N}$ & $47^{\circ} 12^{\prime} 37^{\prime \prime} \mathrm{N}$ & $47^{\circ} 12^{\prime} 37^{\prime \prime} \mathrm{N}$ & $47^{\circ} 12^{\prime} 37^{\prime \prime} \mathrm{N}$ \\
\hline Longitude & $11^{\circ} 06^{\prime} \mathrm{E}$ & $11^{\circ} 06^{\prime} \mathrm{E}$ & $8^{\circ} 24^{\prime} 38^{\prime \prime} \mathrm{E}$ & $8^{\circ} 24^{\prime} 38^{\prime \prime} \mathrm{E}$ & $8^{\circ} 24^{\prime} 38^{\prime \prime} \mathrm{E}$ \\
\hline Elevation (m) & 600 & 600 & 393 & 393 & 393 \\
\hline Management & intensive & extensive & intensive & intensive & intensive \\
\hline MAT $\left({ }^{\circ} \mathbf{C}\right)$ & 8.6 & 8.6 & 9.1 & 9.1 & 9.1 \\
\hline $\mathbf{M A P}(\mathbf{m m})$ & 933 & 933 & 1151 & 1151 & 1151 \\
\hline Snow cover days & $43-54$ & $43-54$ & $<7$ & $<7$ & $<7$ \\
\hline Grass $(\%)$ & 42 & 42 & 80 & 80 & 60 \\
\hline Clover $(\%)$ & $18-26$ & $18-26$ & 20 & 20 & 40 \\
\hline \multirow[t]{2}{*}{ Grazing days $\mathrm{yr}^{-1}$} & 0 & 0 & 2010: 0 & 2010: 50 & 2012: 7 \\
\hline & & & 2011: 18 & 2011: 18 & 2013: 1 \\
\hline \multirow[t]{2}{*}{${\text { Grazing animals } d^{-1}}^{-1}$} & 0 & 0 & 2010: 0 & 2010: 40 - 160 sheep & 2012: 50 sheep \\
\hline & & & 2011: 50 - 60 sheep & 2011: 50 - 60 sheep & 2013: 70 sheep \\
\hline \multirow[t]{3}{*}{ Cutting events } & 2012: 5 & 2012: 3 & 2010: 5 & 2010: 4 & 2012: 5 \\
\hline & 2013: 4 & 2013: 3 & 2011: 5 & 2011: 5 & 2013: 5 \\
\hline & 2014: 5 & $2014: 3$ & & & \\
\hline \multirow{3}{*}{ Harvest C / N (kg ha ${ }^{-1}$ DW) } & 2012: $4790 / 389$ & 2012: 4664 / 273 & 2010: 3449 / 222 & 2010: 1262 / 81 & 2012: $1500 / 96$ \\
\hline & 2013: 6374 / 420 & 2013: 4437 / 247 & 2011: $2468 / 159$ & 2011: $1850 / 119$ & 2013: 4233 / 272 \\
\hline & 2014: $5841 / 289$ & 2014: $3989 / 169$ & & & \\
\hline \multirow[t]{3}{*}{ Fertilization events } & $2012: 5$ & 2012: 1 & 2010: 5 & 2010: 5 & 2012: 6 \\
\hline & 2013: 6 & 2013: 2 & 2011: 6 & 2011: 6 & 2013: 4 \\
\hline & 2014: 4 & 2014: 1 & & & \\
\hline \multirow{3}{*}{ Organic fertilizer $\mathrm{C} / \mathrm{N}\left(\mathrm{kg} \mathrm{ha}^{-1} \mathrm{yr}^{-1}\right)$} & 2012: 2204 / 312 (slurry) & 2012: 389 / 61 (slurry) & 2010: 1426 / 253 (slurry) & 2010: 1487 / 194 (slurry) & 2012: $2233 / 269 \&$ \\
\hline & 2013: $3310 / 365$ (slurry) & 2013: $1071 / 122$ (slurry) & 2011: 1222 / 254 (slurry) & 2011: $1510 / 258$ (slurry) & 2013: 978 / 232 (slurry) \\
\hline & 2014: 2503 / 243 (slurry) & 2014: 288 / 61 (slurry) & & & \\
\hline Mineral fertilizer $\mathbf{N}\left(\mathrm{kg} \mathrm{ha}^{-1} \mathbf{y r}^{-1}\right)$ & 0 & 0 & 0 & 0 & $\begin{array}{l}\text { 2012: } 17 \\
\text { 2013: } 0\end{array}$ \\
\hline $\mathrm{CO}_{2} / \mathrm{N}_{2} \mathrm{O} / \mathrm{CH}_{4}$ flux method & all: $\mathrm{MC} \& \mathrm{AC}$ & all: $\mathrm{MC} \& \mathrm{AC}$ & $\mathrm{EC} / \mathrm{MC} / \mathrm{MC}$ & $\mathrm{EC} / \mathrm{MC} / \mathrm{MC}$ & $\mathrm{EC} / \mathrm{EC} / \mathrm{EC}$ \\
\hline $\mathrm{CO}_{2} / \mathrm{N}_{2} \mathrm{O} / \mathrm{CH}_{4}$ measurement days & 1096 / 626 / 629 & $0 / 659 / 659$ & $676 / 38 / 36$ & $698 / 38 / 37$ & $715 / 694$ / 694 \\
\hline Chamber plots & 6 & 6 & 8 & 8 & 0 \\
\hline $\mathbf{G F}_{\mathrm{RM}}$ window size (days) & 60 & 60 & 30 & 30 & 60 \\
\hline Reference & $\begin{array}{l}\text { Lu, (2016) } \\
\text { Zeeman et al. (2017) }\end{array}$ & Lu, (2016) & Imer et al. (2013) & Imer et al. (2013) & Merbold et al. (2014) \\
\hline
\end{tabular}

II Grass and clover percentages are given as fraction of total dry weight and is not related to spatial coverage;

$\uparrow$ CH-CHA-I2 2010: rolling and resowing in March/April, herbicide in July;

$\S$ CH-CHA 2012: ploughing on 2 February, resowing, rolling, harrowing in March and April, herbicide/pesticide in July and September;

\& During 2012, solid manure was applied in January, otherwise slurry.

Abbreviations: MAP, mean annual precipitation; MAT, mean annual temperature; DW, dry weight; GF ${ }_{\mathrm{RM}}$, gap-filling with running median;

Flux measurement method: AC, automatic chambers; EC, eddy covariance method; MC, manual chambers;

This article is protected by copyright. All rights reserved. 
Table 2 Percentile distribution of measured, non-gapfilled $\mathrm{N}_{2} \mathrm{O}\left(\mathrm{F}_{\mathrm{N} 2 \mathrm{O}}\right)$ and $\mathrm{CH}_{4}\left(\mathrm{~F}_{\mathrm{CH} 4}\right)$ fluxes, soil temperature (TS) and water-filled pore space (WFPS) for data shown in Figure 3-Figure 5 for each site. $\mathrm{P}_{\mathrm{zf}}$ corresponds to the zero-flux percentile, i.e. the percentile rank where the flux was found to be zero; $\mathrm{P}_{25}$ and $\mathrm{P}_{75}$ refer to the $25^{\text {th }}$ and $75^{\text {th }}$ percentile, i.e. values in-between give the interquartile range; $\mathrm{P}_{50}$ corresponds to the $50^{\text {th }}$ percentile (median).

\begin{tabular}{|c|c|c|c|c|c|c|c|c|c|c|}
\hline \multirow[b]{2}{*}{ Site } & \multirow[b]{2}{*}{$\mathbf{P}_{\mathrm{zf}}$} & \multicolumn{3}{|c|}{ Flux $\left(\mu \mathrm{g} \mathrm{m}^{-2} \mathrm{~h}^{-1}\right)$} & \multicolumn{3}{|c|}{$\mathbf{T S}\left({ }^{\circ} \mathbf{C}\right)$} & \multicolumn{3}{|c|}{ WFPS (\%) } \\
\hline & & $\overline{\mathbf{P}_{25}}$ & $\mathbf{P}_{50}$ & $\mathbf{P}_{75}$ & $\overline{\mathbf{P}_{25}}$ & $\mathbf{P}_{50}$ & $\mathbf{P}_{75}$ & $\overline{\mathbf{P}_{25}}$ & $\mathbf{P}_{50}$ & $\mathbf{P}_{75}$ \\
\hline \multicolumn{11}{|l|}{$\mathbf{F}_{\mathrm{N} 2 \mathrm{O}}$} \\
\hline CH-AWS & 0 & 5 & 17 & 73 & 10 & 12 & 12 & 38 & 55 & 64 \\
\hline STU-P & 4 & 5 & 6 & 10 & 11 & 12 & 13 & 44 & 51 & 54 \\
\hline STU-M & 15 & 4 & 8 & 13 & 9 & 11 & 12 & 59 & 62 & 68 \\
\hline FR-LAQ-I & 10 & 3 & 12 & 29 & 7 & 12 & 15 & 59 & 63 & 69 \\
\hline FR-LAQ-E & 9 & 2 & 6 & 13 & 6 & 10 & 14 & 61 & 66 & 70 \\
\hline CH-FRU-I & 2 & 7 & 21 & 33 & 10 & 12 & 14 & 57 & 77 & 82 \\
\hline CH-FRU-E & 0 & 9 & 17 & 23 & 10 & 12 & 14 & 57 & 77 & 82 \\
\hline AT-NEU & 35 & -4 & 4 & 20 & 2 & 11 & 15 & 50 & 61 & 68 \\
\hline DE-GAP & 15 & 2 & 11 & 22 & 10 & 15 & 20 & 59 & 68 & 71 \\
\hline DE-FEN-I & 5 & 10 & 17 & 41 & 6 & 12 & 18 & 55 & 67 & 71 \\
\hline DE-FEN-E & 4 & 6 & 11 & 21 & 7 & 13 & 18 & 54 & 61 & 65 \\
\hline CH-CHA-I1 & 0 & 18 & 39 & 133 & 12 & 16 & 19 & 64 & 82 & 89 \\
\hline CH-CHA-I2 & 1 & 27 & 56 & 238 & 12 & 16 & 19 & 64 & 82 & 89 \\
\hline CH-CHA & 12 & 16 & 56 & 264 & 5 & 13 & 18 & 85 & 91 & 94 \\
\hline Range (min, $\max$ ) & 0,35 & $-4,27$ & 4,56 & 10,264 & 2,12 & 10,16 & 12,20 & 38,85 & 51,91 & 54,94 \\
\hline \multicolumn{11}{|l|}{$\mathbf{F}_{\mathrm{CH} 4}$} \\
\hline CH-AWS & n.a. & -41 & -28 & -18 & 10 & 12 & 12 & 38 & 55 & 64 \\
\hline STU-P & 85 & -40 & -29 & -18 & 11 & 12 & 14 & 41 & 50 & 54 \\
\hline STU-M & 95 & -56 & -40 & -24 & 10 & 11 & 13 & 59 & 62 & 68 \\
\hline CH-FRU-I & 81 & -22 & -17 & -8 & 10 & 12 & 14 & 54 & 77 & 81 \\
\hline CH-FRU-E & 86 & -20 & -12 & -9 & 10 & 12 & 14 & 57 & 77 & 82 \\
\hline AT-NEU & 27 & -6 & 36 & 76 & 2 & 11 & 15 & 50 & 61 & 68 \\
\hline DE-GAP & 77 & -26 & -12 & -1 & 10 & 15 & 20 & 59 & 68 & 71 \\
\hline
\end{tabular}

This article is protected by copyright. All rights reserved. 


\begin{tabular}{|c|c|c|c|c|c|c|c|c|c|c|}
\hline DE-FEN-I & 87 & -18 & -10 & -5 & 6 & 12 & 18 & 55 & 67 & 71 \\
\hline DE-FEN-E & 87 & -18 & -11 & -6 & 7 & 13 & 18 & 54 & 61 & 65 \\
\hline CH-CHA-I1 & 80 & -15 & -14 & -2 & 13 & 16 & 19 & 63 & 82 & 89 \\
\hline CH-CHA-I2 & 81 & -16 & -12 & -4 & 12 & 16 & 19 & 64 & 82 & 89 \\
\hline $\mathrm{CH}-\mathrm{CHA}$ & 36 & -115 & 111 & 364 & 5 & 13 & 18 & 85 & 91 & 94 \\
\hline Range (min, $\max$ ) & 27,95 & $-115,-6$ & $-40,111$ & $-24,364$ & 2,13 & 11,16 & 12,20 & 38,85 & 50,91 & 54,94 \\
\hline
\end{tabular}

Table 3 Regression analysis using daily averages with log-transformed $\mathrm{CH}_{4}\left(\mathrm{~F}_{\mathrm{CH} 4}\right)$ and $\mathrm{N}_{2} \mathrm{O}\left(\mathrm{F}_{\mathrm{N} 2 \mathrm{O}}\right)$ flux rates as dependent variables. Soil temperature (TS) and water-filled pore space (WFPS) were used as driver variables. Before log-transformation, the site-specific minimum flux +1 was added to observed fluxes. Only background fluxes were included in the regression analysis, time periods in temporal proximity to management events (cutting, fertilization) and periods of snow cover were excluded from the analysis. Linear models: $y=a x+b y+c$ for multiple linear regression, $y=\mathrm{dx}+\mathrm{e}$ for simple linear regression. $\mathrm{n}$, number of available measurement days used in the regression analyses; $\mathrm{r}_{\mathrm{adj}}^{2}$, coefficient of determination after adjustment based on the degrees of freedom of the respective model; stars indicate significance levels: $*, P<0.05 ; * *, P<$ $0.01 ; * * *, P<0.001$

\begin{tabular}{|c|c|c|c|c|c|c|c|c|c|c|c|c|c|c|}
\hline \multirow[b]{3}{*}{ Site } & \multirow[b]{3}{*}{$\begin{array}{l}\text { Measurement } \\
\text { technique }\end{array}$} & \multicolumn{5}{|c|}{ Multiple linear regression (TS + WFPS) } & \multicolumn{8}{|c|}{ Simple linear regression } \\
\hline & & \multirow[b]{2}{*}{$\mathbf{n}$} & \multirow[b]{2}{*}{$\mathbf{r}^{2}\left(\mathbf{r}_{\mathrm{adj}}^{2}\right)$} & \multicolumn{3}{|c|}{ Regression coefficients } & \multirow[b]{2}{*}{$\mathbf{n}$} & \multirow[b]{2}{*}{$\mathbf{r}^{2}\left(\mathbf{r}_{\mathrm{adj}}^{2}\right)$} & \multicolumn{2}{|c|}{ Regression coefficients } & \multirow[b]{2}{*}{$\mathbf{n}$} & \multirow[b]{2}{*}{$\mathbf{r}^{2}\left(\mathbf{r a d j}^{2}\right)$} & \multicolumn{2}{|l|}{$\begin{array}{l}\text { Regression } \\
\text { coefficients }\end{array}$} \\
\hline & & & & $\begin{array}{l}\text { c } \\
\text { (intercept) }\end{array}$ & a & $\begin{array}{l}\text { b } \\
\text { (WFPS) }\end{array}$ & & & $\begin{array}{l}\text { e } \\
\text { (intercept) }\end{array}$ & $\begin{array}{l}\text { d } \\
(\mathrm{TS}) \\
\end{array}$ & & & $\begin{array}{l}\text { e } \\
\text { (intercept) }\end{array}$ & $\begin{array}{l}\text { d } \\
\text { (WFPS) }\end{array}$ \\
\hline \multicolumn{15}{|l|}{$\log \left(\mathbf{F}_{\mathrm{N} 2 \mathrm{O}}\right)$} \\
\hline CH-AWS & $\mathrm{MC}$ & 19 & $0.31(0.22)$ & -0.269 & 0.011 & $0.007 *$ & 19 & $0.07(0.01)$ & -0.056 & 0.021 & 19 & $0.29(0.25)^{*}$ & -0.164 & $0.007 *$ \\
\hline AT-STU-P & MC & 21 & $0.13(0.04)$ & 0.024 & 0.003 & 0.000 & 21 & $0.13(0.09)$ & 0.032 & 0.003 & 21 & $0.00(-0.05)$ & 0.072 & 0.000 \\
\hline AT-STU-M & $\mathrm{MC}$ & 18 & $0.46(0.38)^{*}$ & $-0.235^{*}$ & $0.010 * *$ & $0.003^{*}$ & 18 & $0.24(0.19)^{*}$ & 0.009 & $0.008^{*}$ & 18 & $0.08(0.02)$ & -0.035 & 0.002 \\
\hline FR-LAQ-I & $\mathrm{EC}$ & 570 & $0.10(0.10)^{* * *}$ & -0.213 & $0.022 * * *$ & 0.003 & 684 & $0.05(0.05) * * *$ & 0.027 & $0.013 * * *$ & 570 & $0.01(0.01)^{*}$ & $0.422 * * *$ & $-0.004^{*}$ \\
\hline FR-LAQ-E & $\mathrm{AC}$ & 591 & $0.10(0.09)^{* * *}$ & -0.198 & $0.021 * * *$ & *0.002 & 711 & $0.05(0.04)^{* * *}$ & 0.033 & $12 * * *$ & 591 & $0.01(0.01)^{*}$ & $0.404 * * *$ & $-0.003 *$ \\
\hline CH-FRU-I & $\mathrm{MC}$ & 33 & $0.24(0.19)^{*}$ & -0.085 & $0.010 * *$ & $0.002 *$ & 33 & $0.11(0.08)$ & $0.099 *$ & 0.006 & 33 & $0.01(-0.02)$ & $0.130^{*}$ & 0.001 \\
\hline CH-FRU-E & $\mathrm{MC}$ & 27 & $0.47(0.43)^{* * *}$ & -0.097 & $0.012 * * *$ & *0.001** & 27 & $0.27(0.24) * *$ & 0.029 & $0.008 * *$ & 27 & $0.05(0.01)$ & $0.095^{*}$ & 0.001 \\
\hline AT-NEU & $\mathrm{EC}$ & 400 & $0.14(0.10)^{* * *}$ & $0.460 * * *$ & $0.003 * *$ & $-0.002 * * *$ & 400 & $0.06(0.06)^{* * *}$ & $0.321 * * *$ & $0.005^{* * *}$ & 400 & $0.12(0.11)^{* * *}$ & $0.513 * * *$ & $-0.002 * * *$ \\
\hline DE-GAP & MC & 59 & $0.21(0.18)^{* *}$ & $-0.204 *$ & $0.005^{*}$ & $0.004 * * *$ & 59 & $0.01(-0.01)$ & $0.108 * *$ & 0.002 & 67 & $0.08(0.06)^{*}$ & -0.028 & $0.002 *$ \\
\hline DE-FEN-I & $\mathrm{AC}$ & 244 & $0.03(0.03)^{*}$ & 0.151 & 0.004 & 0.000 & 506 & $0.08(0.08)^{* * *}$ & $0.078 * * *$ & $0.006^{* * *}$ & 244 & $0.02(0.02)^{*}$ & $0.306 * * *$ & $-0.002 *$ \\
\hline DE-FEN-E & $\mathrm{AC}$ & 299 & $0.02(0.02)^{*}$ & -0.013 & 0.002 & $0.002 *$ & 547 & $0.01(0.01)^{* *}$ & $0.107 * * *$ & $0.002 * *$ & 303 & $0.02(0.01)^{*}$ & 0.062 & $0.002 *$ \\
\hline CH-CHA-I1 & $1 \mathrm{MC}$ & 31 & $0.19(0.13)$ & -1.135 & 0.028 & $0.014 *$ & 33 & $0.02(-0.02)$ & 0.228 & 0.009 & 31 & $0.08(0.05)$ & -0.278 & 0.008 \\
\hline CH-CHA-I2 & $2 \mathrm{MC}$ & 54 & $0.14(0.10)^{*}$ & -1.067 & $0.038 * *$ & $0.012 *$ & 56 & $0.05(0.04)$ & 0.121 & 0.020 & 54 & $0.01(-0.01)$ & 0.168 & 0.003 \\
\hline CH-CHA & $\mathrm{EC}$ & 610 & $0.15(0.15)^{* * *}$ & $3.407 * * *$ & $-0.008 *$ & $-0.025 * * *$ & 610 & $0.02(0.02)^{* * * *}$ & $1.003 * * *$ & $0.010 * * *$ & 610 & $0.14(0.14)^{* * *}$ & $2.981 * * *$ & $-0.021 * * *$ \\
\hline \multicolumn{15}{|l|}{$\log \left(\mathrm{F}_{\mathrm{CH} 4}\right)$} \\
\hline CH-AWS & $\mathrm{MC}$ & 19 & $0.77(0.74) * * *$ & 0.047 & -0.015 & $0.009 * * *$ & 19 & $0.00(-0.06)$ & 0.304 & 0.004 & 19 & $0.72(0.71)^{* * * *}$ & -0.085 & $0.009 * * *$ \\
\hline AT-STU-P & $\mathrm{MC}$ & 26 & $0.03(-0.05)$ & $1.809 * * *$ & -0.006 & 0.000 & 26 & $0.03(-0.01)$ & $1.792 * * *$ & -0.006 & 26 & $0.00(-0.04)$ & $1.717 * * *$ & 0.000 \\
\hline AT-STU-M & $\mathrm{MC}$ & 20 & $0.05(-0.06)$ & 0.285 & 0.021 & 0.004 & 20 & $0.05(-0.01)$ & $0.548 *$ & 0.019 & 20 & $0.00(-0.05)$ & 0.687 & 0.001 \\
\hline
\end{tabular}

This article is protected by copyright. All rights reserved. 


\begin{tabular}{|c|c|c|c|c|c|c|c|c|c|c|c|c|c|c|}
\hline FR-LAQ-I A & $\mathrm{AC}$ & 148 & $0.24(0.23)^{* * *}$ & 0.552 & $0.182 * *$ & *0.011 & 178 & $0.24(0.24) * * *$ & $1.388 * * *$ & $0.171 * * *$ & 148 & $0.00(-0.00)$ & $4.393 * * *$ & -0.011 \\
\hline FR-LAQ-E n. & n.a. & n.a. & n.a. & n.a. & n.a. & n.a. & n.a. & n.a. & n.a. & n.a. & n.a. & n.a. & n.a. & n.a. \\
\hline CH-FRU-I M & $\mathrm{MC}$ & 32 & $0.19(0.13)$ & -0.038 & 0.006 & $0.004 *$ & 32 & $0.00(-0.03)$ & $0.363 * * *$ & -0.003 & 32 & $0.16(0.14)^{*}$ & 0.082 & $0.004 *$ \\
\hline CH-FRU-E N & $\mathrm{MC}$ & 27 & $0.40(0.35)^{* *}$ & 0.014 & -0.003 & $0.004 * *$ & 27 & $0.11(0.07)$ & $0.430 * * *$ & -0.014 & 27 & $0.40(0.37)^{* * *}$ & -0.043 & $0.005 * * *$ \\
\hline AT-NEU E & EC & 398 & $0.04(0.03)^{* * *}$ & $1.716 * * *$ & $0.008 * *$ & $* 0.002 *$ & 398 & $0.02(0.02)^{* *}$ & $1.855 * * *$ & $0.006^{* *}$ & 398 & $0.01(0.00)$ & $1.865^{* * *}$ & 0.001 \\
\hline DE-GAP & $\mathrm{MC}$ & 58 & $0.40(0.37)^{* * *}$ & 0.280 & -0.004 & $0.010 * * *$ & 58 & $0.13(0.12)^{* *}$ & $0.988 * * *$ & $-0.011 * *$ & 68 & $0.18(0.16)^{* * *}$ & 0.282 & $0.008 * * *$ \\
\hline DE-FEN-I & $\mathrm{AC}$ & 244 & $0.22(0.21)^{* * *}$ & $0.185^{*}$ & 0.000 & $0.005 * * *$ & 509 & $0.14(0.14)^{* * *}$ & $0.599 * * *$ & $-0.007 * * *$ & 244 & $0.22(0.22)^{* * *}$ & $0.196 * * *$ & $0.005 * * *$ \\
\hline DE-FEN-E A & $\mathrm{AC}$ & 299 & $0.32(0.32)^{* * *}$ & $0.226 * * *$ & -0.002 & $0.006 * * *$ & 549 & $0.16(0.16)^{* * *}$ & $0.628 * * *$ & $-0.008 * * *$ & 303 & $0.30(0.29)^{* * *}$ & $0.149 * * *$ & $0.007 * * *$ \\
\hline CH-CHA-I1 N & $\mathrm{MC}$ & 29 & $0.10(0.03)$ & 0.191 & -0.006 & 0.002 & 31 & $0.07(0.04)$ & $0.329 * * *$ & -0.008 & 29 & $0.07(0.03)$ & 0.002 & 0.003 \\
\hline $\mathrm{CH}-\mathrm{CHA}-\mathrm{I} 2 \mathrm{M}$ & $\mathrm{MC}$ & 54 & $0.20(0.17)^{* *}$ & -0.099 & 0.000 & $0.004 * *$ & 55 & $0.06(0.04)$ & $0.300 * * *$ & -0.006 & 54 & $0.20(0.19)^{* * *}$ & -0.111 & $0.004 * * *$ \\
\hline $\mathrm{CH}-\mathrm{CHA} \quad \mathrm{E}$ & $\mathrm{EC}$ & 609 & $0.00(-0.00)$ & $3.154 * * *$ & 0.003 & 0.000 & 609 & $0.00(0.00)$ & $3.187 * * *$ & 0.002 & 609 & $0.00(-0.00)$ & $3.305^{* * *} *$ & -0.001 \\
\hline
\end{tabular}

Table 4 Annual cumulative $\mathrm{CO}_{2}, \mathrm{~N}_{2} \mathrm{O}$ and $\mathrm{CH}_{4}$ site budgets, calculated from gap-filled data. For sites where more than one year of measurements were available, multi-year averages \pm the standard error of the mean are given. Net greenhouse gas balance (NGB) is given as the sum of $\mathrm{CO}_{2}$ flux $+\mathrm{N}_{2} \mathrm{O}$ flux $+\mathrm{CH}_{4}$ flux. $\mathrm{CO}_{2}$ flux offset represents the percentage of $\mathrm{CO}_{2}$ uptake that is offset by $\mathrm{N}_{2} \mathrm{O}$ and $\mathrm{CH}_{4}$ fluxes, i.e. corresponds to the ratio between the sum of $\mathrm{N}_{2} \mathrm{O}$ flux $+\mathrm{CH}_{4}$ flux and the $\mathrm{CO}_{2}$ flux. For NGB and the $\mathrm{CO}_{2}$ flux offset, numbers are shown in brackets if not all three compounds were measured.

\begin{tabular}{|c|c|c|c|c|c|c|}
\hline \multirow[t]{2}{*}{ Site } & \multirow[t]{2}{*}{ Year } & \multicolumn{4}{|c|}{ Cumulative budgets ( $\mathrm{g} \mathrm{CO}_{2}$-eq. $\mathrm{m}^{-2} \mathrm{yr}^{-1}$ ) } & \multirow[t]{2}{*}{$\mathrm{CO}_{2}$ flux offset } \\
\hline & & $\mathrm{CO}_{2}$ flux & $\mathrm{N}_{2} \mathrm{O}$ flux & $\mathrm{CH}_{4}$ flux & NGB & \\
\hline $\mathrm{CH}-\mathrm{AWS}$ & $2010 / 11$ & -1783 & 107 & -9 & -1685 & $5 \%$ \\
\hline AT-STU-P & 2011 & n.a. & 18 & -7 & (11) & n.a. \\
\hline AT-STU-M & 2011 & n.a. & 20 & -9 & (11) & n.a. \\
\hline \multirow[t]{7}{*}{ FR-LAQ-I } & 2008 & -1537 & 93 & n.a. & $(-1444)$ & $(6 \%)$ \\
\hline & 2009 & -1444 & 247 & n.a. & $(-1197)$ & $(17 \%)$ \\
\hline & 2010 & -814 & 48 & 388 & -378 & $54 \%$ \\
\hline & 2011 & -1019 & 68 & 588 & -363 & $64 \%$ \\
\hline & 2012 & n.a. & 56 & n.a. & (56) & n.a. \\
\hline & 2013 & n.a. & 25 & n.a. & (25) & n.a. \\
\hline & $2008-2013$ & $-1204 \pm 172$ & $90 \pm 33$ & $488 \pm 100$ & -626 & $48 \%$ \\
\hline \multirow[t]{7}{*}{ FR-LAQ-E } & 2008 & -1276 & 17 & n.a. & $(-1259)$ & $(1 \%)$ \\
\hline & 2009 & -657 & 30 & n.a. & $(-627)$ & $(5 \%)$ \\
\hline & 2010 & -916 & 20 & n.a. & $(-897)$ & $(2 \%)$ \\
\hline & 2011 & n.a. & 23 & n.a. & (23) & n.a. \\
\hline & 2012 & n.a. & 16 & n.a. & (16) & n.a. \\
\hline & 2013 & n.a. & 10 & n.a. & (10) & n.a. \\
\hline & 2008-2013 & $-950 \pm 179$ & $19 \pm 3$ & n.a. & $(-931)$ & $(2 \%)$ \\
\hline CH-FRU-I & $2010 / 11$ & -2806 & 47 & -2 & -2761 & $2 \%$ \\
\hline
\end{tabular}

This article is protected by copyright. All rights reserved. 


\begin{tabular}{|c|c|c|c|c|c|c|}
\hline CH-FRU-E & 2010/11 & -1371 & 40 & -4 & -1335 & $3 \%$ \\
\hline \multirow[t]{3}{*}{ AT-NEU } & 2010 & -111 & 10 & 14 & -87 & $22 \%$ \\
\hline & 2011 & -70 & 30 & 11 & -29 & $59 \%$ \\
\hline & 2010-2011 & $-91 \pm 20$ & $20 \pm 10$ & $13 \pm 2$ & -58 & $36 \%$ \\
\hline \multirow[t]{3}{*}{ DE-GAP } & 2012 & n.a. & 25 & 1 & (26) & n.a. \\
\hline & 2013 & n.a. & 27 & -3 & (24) & n.a. \\
\hline & 2012-2013 & n.a. & $26 \pm 1$ & $-1 \pm 2$ & (25) & n.a. \\
\hline \multirow[t]{4}{*}{ DE-FEN-I } & 2012 & -737 & 101 & 9 & -627 & $15 \%$ \\
\hline & 2013 & -954 & 57 & 1 & -896 & $6 \%$ \\
\hline & 2014 & -1238 & 37 & -1 & -1202 & $3 \%$ \\
\hline & 2012-2014 & $-976 \pm 145$ & $65 \pm 19$ & $3 \pm 3$ & -909 & $7 \%$ \\
\hline \multirow[t]{4}{*}{ DE-FEN-E } & 2012 & n.a. & 38 & 4 & (42) & n.a. \\
\hline & 2013 & n.a. & 52 & -3 & (49) & n.a. \\
\hline & 2014 & n.a. & 36 & -3 & (33) & n.a. \\
\hline & 2012-2014 & n.a. & $42 \pm 5$ & $-1 \pm 2$ & (41) & n.a. \\
\hline CH-CHA-I1 & 2010/11 & -2403 & 245 & -2 & -2160 & $10 \%$ \\
\hline CH-CHA-I2 & $2010 / 11$ & -912 & 370 & -2 & -544 & $40 \%$ \\
\hline \multirow[t]{3}{*}{ CH-CHA } & $2012 \S$ & 1246 & 1157 & 43 & 2446 & $-96 \%$ \\
\hline & 2013 & -4671 & 119 & 38 & -4514 & $3 \%$ \\
\hline & 2012-2013 & $-1713 \pm 2959$ & $638 \pm 519$ & $41 \pm 3$ & -1034 & $40 \%$ \\
\hline Mean across sites & & & & & & $21 \pm 6 \%$ \\
\hline
\end{tabular}

$\S$ CH-CHA 2012: year of grassland restoration (including ploughing)

This article is protected by copyright. All rights reserved. 
Table 5 Literature overview of $\mathrm{N}_{2} \mathrm{O}$ and $\mathrm{CH}_{4}$ measurements over grassland sites in comparison to gap-filled findings in this study, flux rates are given in $\mu \mathrm{g} \mathrm{m}^{-2} \mathrm{~h}^{-1}$.

\begin{tabular}{|c|c|c|c|c|c|c|c|c|c|c|c|c|c|}
\hline \multirow[b]{2}{*}{ ID Site } & \multirow{3}{*}{ Reference } & & \multirow{2}{*}{ Time } & \multirow[b]{2}{*}{ Method } & \multirow{2}{*}{$\begin{array}{l}\text { Sampling } \\
\text { freq. }\end{array}$} & \multirow{2}{*}{ Management } & \multirow{3}{*}{$\begin{array}{l}\text { Min } \\
0^{\text {DY }}\end{array}$} & \multirow[b]{2}{*}{ Max } & \multirow{2}{*}{$\begin{array}{l}\mathbf{N}_{2} \mathbf{O} \\
\text { Mean } \\
\text { SEM }\end{array}$} & \multirow[b]{2}{*}{ Min } & \multirow{2}{*}{ Max } & \multicolumn{2}{|l|}{$\mathbf{C H}_{4}$} \\
\hline & & & & & & & & & & & & Mean \pm SEM & Notes \\
\hline 1 CH-AWS & & $2010 / 11$ & $\begin{array}{lll}\text { YR } \\
\text { GWG }\end{array}$ & $\mathrm{MC}$ & & & & & & $\begin{array}{ll}-57^{\mathrm{DY}} \\
86^{\mathrm{DY}}\end{array}$ & $\begin{array}{l}-15^{\mathrm{DY}} \\
7\end{array}$ & $\begin{array}{ll}-30 \mathrm{YR} \\
-22 \mathrm{DY}\end{array}$ & II \\
\hline 2 AT-STU-P & this study & 2011 & GWS & $\mathrm{MC}$ & WK & G, F & 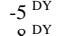 & $22^{\mathrm{DY}}$ & $7^{\mathrm{DY}}$ & $-86^{\mathrm{DY}}$ & $75^{\text {DY }}$ & $-23^{\mathrm{DY}}$ & II \\
\hline 3 AT-STU-M & this study & 2011 & GWS & MC & WK & G, C, F & -8 DY & $26^{\text {DY }}$ & 8 & $-114^{\mathrm{DY}}$ & $49^{\mathrm{DY}}$ & & II \\
\hline 4 FR-LAQ-I & this study & $\begin{array}{l}\mathrm{CH}_{4}: 2010-2011, \mathrm{~N}_{2} \mathrm{O}: 2008- \\
2013\end{array}$ & $\begin{array}{l}\mathrm{CH}_{4}: \mathrm{GWS}, \mathrm{N}_{2} \mathrm{O}: \\
\mathrm{YR}\end{array}$ & $\mathrm{CH}_{4}: \mathrm{EC}, \mathrm{N}_{2} \mathrm{O}: \mathrm{AC}$ & DY & $\mathrm{G}, \mathrm{F}$ & $-94^{\mathrm{DY}}$ & $\begin{array}{l}1298 \\
\mathrm{DY}\end{array}$ & $34 \pm 13^{\mathrm{YR}}$ & $-206^{\mathrm{DY}}$ & $12459^{\mathrm{DY}}$ & $1639 \pm 336^{\mathrm{DY}}$ & cows in footprint \\
\hline 5 FR-LAQ-E & this study & $2008-2013$ & YR & $\mathrm{AC}$ & DY & G & $-32^{\mathrm{DY}}$ & 199 DY & $7 \pm 1^{\mathrm{YR}}$ & & & & \\
\hline 6 CH-FRU-I & this study & 2010/11 & YR & $\mathrm{MC}$ & $\sim$ WK & G, C, F & $-7^{\mathrm{DY}}$ & $126^{\mathrm{DY}}$ & & $-37^{\mathrm{DY}}$ & $63^{\text {DY }}$ & -6 & II \\
\hline 7 CH-FRU-E & this study & 2010/11 & YR & MC & $\sim$ WK & G, C, F & $0^{\mathrm{DY}}$ & $282^{\mathrm{DY}}$ & & $-57^{\text {DY }}$ & $24^{\mathrm{DY}}$ & & II \\
\hline 8 AT-NEU & this study & 2011 & YR & $\mathrm{EC}$ & $20 \mathrm{~Hz}$ & $\mathrm{C}, \mathrm{F}$ & $\begin{array}{l}-277 \\
\mathrm{DY}\end{array}$ & $121^{\mathrm{DY}}$ & $8 \pm 4^{\mathrm{YR}}$ & $\begin{array}{l}-1911 \\
\text { DY }\end{array}$ & $602^{\mathrm{DY}}$ & $41 \pm 5^{\mathrm{YR}}$ & \\
\hline 9 DE-GAP & this study & 2012-2013 & YR & MC & WK & $\mathrm{C}, \mathrm{F}$ & $-111^{\mathrm{DY}}$ & $127^{\mathrm{DY}}$ & $10 \pm 0$ & $-70^{\mathrm{DY}}$ & $404^{\mathrm{DY}}$ & $-4 \pm 7^{\mathrm{YR}}$ & \\
\hline 10 DE-FEN-I & this study & 2012-2014 & YR & $\mathrm{AC}$ & DY & $\mathrm{C}, \mathrm{F}$ & $-8^{\mathrm{DY}}$ & $\begin{array}{l}2055 \\
\text { DY }\end{array}$ & $25 \pm 7^{\mathrm{YR}}$ & $-57^{\mathrm{DY}}$ & $6377^{\mathrm{DY}}$ & $11 \pm 10^{\mathrm{YR}}$ & \\
\hline 11 DE-FEN-E & this study & 2012-2014 & YR & $\mathrm{AC}$ & DY & $\mathrm{C}, \mathrm{F}$ & $-8^{\mathrm{DY}}$ & $366^{\mathrm{DY}}$ & $16 \pm 2^{\mathrm{YR}}$ & $-54^{\mathrm{DY}}$ & $8907^{\text {DY }}$ & $-2 \pm 8^{\mathrm{YR}}$ & \\
\hline 12 CH-CHA-I1 & this study & 2010/11 & YR & MC & $\sim \mathrm{WK}$ & G, C, F & $-1^{\mathrm{DY}}$ & $849^{\mathrm{DY}}$ & 94 & $-23^{\mathrm{DY}}$ & $111^{\text {DY }}$ & & II \\
\hline 13 СH-CHA-I2 & this study & $2010 / 11$ & YR & MC & $\sim \mathrm{WK}$ & G, C, F & $-4^{\mathrm{DY}}$ & 1529 & 142 & $-28^{\mathrm{DY}}$ & $20^{\text {DY }}$ & -6 & $\mathbb{\pi}$ \\
\hline 14 CH-CHA & this study & 2012-2013 & YR & EC & $20 \mathrm{~Hz}$ & $\mathrm{G}, \mathrm{C}, \mathrm{F}$ & $\begin{array}{l}-803 \\
\mathrm{DY}\end{array}$ & $\begin{array}{l}4868 \\
\mathrm{DY}\end{array}$ & $244 \pm 199$ & $\begin{array}{l}-1327 \\
\mathrm{DY}\end{array}$ & $4234^{\mathrm{DY}}$ & $136 \pm 8$ & $\begin{array}{l}\text { 2012: grassland } \\
\text { restoration }\end{array}$ \\
\hline 15 Inner Mongolia & Wolf et al. (2010) & 2007/2008 & YR & $\mathrm{AC}$ & $>$ DY & none & $-8^{\mathrm{SM}}$ & $75^{\text {SM }}$ & 4 & & & & steppe grassland \\
\hline 16 LCRC, USA & Chiavegato et al. (2015) & 2012-2013 & GZS & $\mathrm{MC}$ & DY & none & $0^{\mathrm{WW}}$ & $5^{\mathrm{wW}}$ & $2 \pm 2^{\mathrm{YR}}$ & $-45^{\mathrm{ww}}$ & $0^{\mathrm{ww}}$ & $-23 \pm 23^{\mathrm{YR}}$ & \\
\hline 17 Inner Mongolia & Wolf et al. (2010) & 2007/2008 & YR & $\mathrm{AC}$ & $>$ DY & G & $-9^{\mathrm{SM}}$ & $31^{\mathrm{SM}}$ & & & & & steppe grassland \\
\hline 18 LCRC, USA & Chiavegato et al. (2015) & 2011-2013 & GZS & $\mathrm{MC}$ & DY & G & $7^{\mathrm{ww}}$ & $64^{\mathrm{ww}}$ & $41 \pm 17^{\mathrm{YR}}$ & -35 ww & $145^{\mathrm{ww}}$ & $48 \pm 52^{\mathrm{YR}}$ & II, *, irrigated \\
\hline 19 LCRC, USA & Chiavegato et al. (2015) & 2011-2013 & GZS & MC & DY & G & $6^{\mathrm{ww}}$ & $83^{\mathrm{ww}}$ & $39 \pm 23^{\text {YR }}$ & $-55^{\mathrm{ww}}$ & $125 \mathrm{ww}$ & $43 \pm 53^{\text {YR }}$ & \\
\hline $20 \begin{array}{l}\text { Estero Dulce, MX } \\
\text { Boquilla de Oro, MX }\end{array}$ & $\begin{array}{l}\text { Hernandez et al. (2014) } \\
\text { Hernandez et al. (2014) }\end{array}$ & 2010-2012 & YR & MC & bi-MN & G & & & & $6070^{\mathrm{DS}}$ & ${ }_{\mathrm{RS}}^{181210}$ & $116760^{\mathrm{YR}}$ & If, flooded grassland \\
\hline $21 \mathrm{Nam} \mathrm{Co}, \mathrm{CN}$ & Wei et al. (2014) & 2009-2013 & GWS & MC & wK & G & & & & $-96^{\mathrm{YR}}$ & -49 YR & $-72 \pm 3^{\mathrm{YR}}$ & II, steppe \\
\hline $22 \mathrm{Nam} \mathrm{Co,} \mathrm{CN}$ & Wei et al. (2014) & 2012-2013 & GWS & MC & WK & G & & & & $-74^{\mathrm{YR}}$ & $-37^{\mathrm{YR}}, \mathrm{P}$ & $-59 \pm 4^{\mathrm{YR}}$ & II, meadow \\
\hline 23 Bugac, HU & Soussana et al. (2007) & 2002-2004 & YR & $\begin{array}{l}\text { CH4: EST, N2O: MC, } \\
\text { TDL }\end{array}$ & & G & $15^{\mathrm{YR}}$ & $18^{\mathrm{YR}}$ & $17 \pm 1^{\mathrm{YR}}$ & $117^{\mathrm{YR}}$ & $218^{\mathrm{YR}}$ & $167 \pm 50^{\mathrm{YR}}$ & $\dagger$ \\
\hline 24 Laqueuille, FR (E) & Soussana et al. (2007) & 2002-2004 & YR & $\begin{array}{l}\text { CH4: SF6, N2O: MC, } \\
\text { TDL }\end{array}$ & & G & $3^{\mathrm{YR}}$ & $3^{\mathrm{YR}}$ & $3 \pm 0^{\mathrm{YR}}$ & $636^{\mathrm{YR}}$ & $719^{\mathrm{YR}}$ & $678 \pm 42^{\mathrm{YR}}$ & $\dagger$ \\
\hline 25 Haibei, CN & Li et al. (2015) & 2013 & GWS & MC & DY & G & $-2^{\mathrm{MN}}$ & $9^{\mathrm{MN}}$ & $4 \pm 3^{\mathrm{MN}}$ & -17 MN & $13^{\mathrm{MN}}$ & $2 \pm 9^{\mathrm{MN}}$ & II, \#, alpine meadow \\
\hline 26 Haibei, CN & Li et al. (2015) & 2013 & GWS & $\mathrm{MC}$ & DY & G & $-1^{\mathrm{MN}}$ & $11^{\mathrm{MN}}$ & $5 \pm 3^{\mathrm{MN}}$ & $-2^{\mathrm{MN}}$ & $25^{\mathrm{MN}}$ & $12 \pm 8^{\mathrm{MN}}$ & $\begin{array}{l}\text { II, \#, alpine steppe } \\
\$\end{array}$ \\
\hline 27 MUDF4, NZ & Bhandral et al. (2010) & $2003 / 04$ & GWS, WIN & MC & DY & G & $98^{\mathrm{DY}}$ & $1074^{\mathrm{DY}}$ & $301 \pm 40$ & & & & \\
\hline & & $\begin{array}{l}2010 \\
2007-2010\end{array}$ & GWS & EC & $20 \mathrm{~Hz}$ & G & & & & $0^{\mathrm{DY}}$ & $4167^{\mathrm{DY}}$ & $1043^{\mathrm{DY}}$ & sheep pasture \\
\hline $\begin{array}{l}29 \text { Sherman Island, US } \\
30 \text { Dorinne BE }\end{array}$ & $\begin{array}{l}\text { Baldocchi et al. (2012) } \\
\text { Dumortier et al (2017) }\end{array}$ & $\begin{array}{l}2007-2010 \\
2013\end{array}$ & GWS & EC & $10 \mathrm{~Hz}$ & G & & & & & & $1320 \pm 1014{ }^{\mathrm{YR}}$ & peatland pasture, cows \\
\hline & & 2013 & & EC & $10 \mathrm{~Hz}$ & G & & & & 63 & 14554 & $1107^{\mathrm{YR}}$ & $\&$, cattle pasture \\
\hline $\begin{array}{l}31 \text { Mooloolah Valley, } \\
\mathrm{NZ}\end{array}$ & Rowlings et al. (2015) & 2007-2008 & YR & $\mathrm{AC}$ & DY & G & $1^{\mathrm{DY}}$ & $761^{\mathrm{DY}}$ & $31 \pm 8^{\mathrm{YR}}$ & & & & subtropical pasture \\
\hline 32 Oensingen, $\mathrm{CH}$ (E) & Soussana et al. (2007) & 2002-2004 & YR & MC, TDL & & C & $-4^{\mathrm{YR}}$ & $-4^{\mathrm{YR}}$ & $\begin{array}{l}-4 \pm 0^{\mathrm{YR}} \\
{ }^{\mathrm{SSUM}}\end{array}$ & & & & \\
\hline 33 Sapporo, JP & Kim \& Tanaka (2015) & 1996/97 & GWS, WIN & $\mathrm{MC}$ & $>=\mathrm{MN}$ & C & $4^{\mathrm{DY}}$ & $14^{\mathrm{DY}}$ & $8^{\text {SUM }} / 13^{\text {WIN }}$ & $-24^{\mathrm{DY}}$ & $0^{\text {DY }}$ & $-10^{\text {SUM } / 0 \text { WIN }}$ & \\
\hline 34 Dümmer peatland, DE & Beyer et al. (2015) & 2007-2011 & YR & MC & bi-WK & C & $0^{\text {YR }}$ & $2^{\mathrm{YR}}$ & $10 \pm 7^{\mathrm{YR}}$ & $-47^{\mathrm{YR}}$ & $48^{\mathrm{YR}}$ & $-14 \pm 8$ SEM & fen grassland \\
\hline 35 Nasu, JP & Mori \& Hojito (2014) & 2008-2010 & YR & MC & $\sim$ WK & $\mathrm{C}, \mathrm{F}$ & $-26^{\mathrm{DY}}$ & $111^{\mathrm{DY}}$ & $10 \pm 4^{\mathrm{YR}}$ & $-173^{\text {DY }}$ & $167^{\mathrm{DY}}$ & $-18 \pm 0^{\mathrm{YR}}$ & F: PK \\
\hline 36 Nasu, JP & Mori \& Hojito (2014) & 2008-2010 & YR & $\mathrm{MC}$ & $\sim \mathrm{WK}$ & $\mathrm{C}, \mathrm{F}$ & $-33^{\mathrm{DY}}$ & $1493^{\text {DY }}$ & $84 \pm 37$ YR & $-173^{\text {DY }}$ & $3028^{\mathrm{DY}}$ & $16 \pm 9^{\mathrm{YR}}$ & F: SL, PK \\
\hline 37 Nasu, JP & Mori \& Hojito (2014) & 2008-2010 & YR & MC & $\sim \mathrm{WK}$ & $\mathrm{C}, \mathrm{F}$ & $-13^{\mathrm{DY}}$ & $1755^{\mathrm{DY}}$ & $88 \pm 34$ YR & $-156^{\mathrm{DY}}$ & $334^{\mathrm{DY}}$ & $-15 \pm 8^{\mathrm{YR}}$ & F: MA, PK \\
\hline 38 Oensingen, $\mathrm{CH}$ (I) & Soussana et al. (2007) & 2002-2004 & YR & MC, TDL & & $\mathrm{C}, \mathrm{F}$ & $19^{\mathrm{YR}}$ & $35^{\mathrm{YR}}$ & $27 \pm 8^{\mathrm{YR}}$ & & & & \\
\hline 39 Lille Valby, DK & Soussana et al. (2007) & 2002-2004 & YR & MC, TDL & & $\mathrm{C}, \mathrm{F}$ & $5^{\mathrm{YR}}$ & $14^{\mathrm{YR}}$ & $10 \pm 4^{\mathrm{YR}}$ & & & & \\
\hline 40 Oukoop, NL & Kroon et al. (2010b) & 2006-2008 & YR & $\mathrm{EC}, \mathrm{QCL}$ & & $\mathrm{C}, \mathrm{F}$ & $274^{\mathrm{YR}}$ & $285^{\mathrm{YR}}$ & $274^{\mathrm{YR}}$ & $1701^{\mathrm{YR}}$ & $2009^{\mathrm{YR}}$ & $1884^{\mathrm{YR}}$ & fen meadow \\
\hline 41 Edinburgh, GB & Cowan et al. (2015) & 2013 & SUM & $\mathrm{MC}$ & >DY & G, F & 11 & 7022 & $47^{\mathrm{DY}}$ & & & & $\S$, sheep \\
\hline 42 Sherman Island, US & Teh et al. (2011) & $2007 / 08$ & YR & EC & $10 \mathrm{~Hz}$ & $\mathrm{G}, \mathrm{F}$ & & & & & & $312^{\mathrm{YR}} \mathrm{Y}=\mathrm{C}$ & peatland pasture, daytime \\
\hline 43 Sherman Island, US & Teh et al. (2011) & $2007 / 08$ & YR & $\mathrm{MC}$ & wK & G, F & $196^{\text {DY }}$ & 7397 & $419^{\mathrm{YR}}$ & & & $1436^{\mathrm{YR}}$ & II, peatland pasture \\
\hline 44 Laqueuille, FR (I) & Soussana et al. (2007) & 2002-2004 & YR & $\begin{array}{l}\text { CH4: SF6, N2O: MC, } \\
\text { TDL }\end{array}$ & & G, F & $12^{\mathrm{YR}}$ & $14^{\mathrm{YR}}$ & $13 \pm 1^{\mathrm{YR}}$ & $1255^{\mathrm{YR}}$ & $1322^{\mathrm{YR}}$ & $1288 \pm 33^{\text {YR }}$ & $\dagger$ \\
\hline 45 Malga Arpaco, IT & Soussana et al. (2007) & 2002-2004 & YR & $\begin{array}{l}\text { CH4: EST, N2O: MC, } \\
\text { TDL }\end{array}$ & & G, F & $0^{\mathrm{YR}}$ & $0^{\mathrm{YR}}$ & $0^{\mathrm{YR}}$ & $301^{\mathrm{YR}}$ & $301^{\mathrm{YR}}$ & $301 \pm 0^{\mathrm{YR}}$ & $\dagger$ \\
\hline 46 Easter Bush, GB & Jones et al. (2011) & 2003/07/08 & GWS & MC & & G, F & $128^{\mathrm{CP}}$ & $876^{\mathrm{CP}}$ & $415 \pm 120^{\mathrm{CP}}$ & & & & ${ }^{* * *}$ \\
\hline 47 Easter Bush, GB & Jones et al. (2011) & 2003/07/08 & GWS & EC & & G, F & $69^{\mathrm{CP}}$ & $1472^{\mathrm{CP}}$ & $411 \pm 196^{\mathrm{CP}}$ & & & & *** \\
\hline 48 MUDF4, NZ & Bhandral et al. (2010) & 2003/04 & GWS, WIN & $\mathrm{MC}$ & DY & G, F & $164^{\mathrm{DY}}$ & 2645 & $631 \pm 109$ & & & & $\$$, irrigated \\
\hline
\end{tabular}

This article is protected by copyright. All rights reserved. 


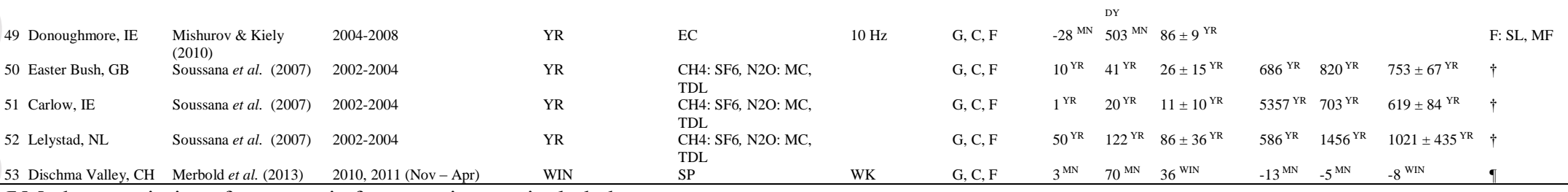
II Methane emissions from enteric fermentation not included.

* Measurements were only carried out during a 14d time span after grazing.

$\uparrow \mathrm{CH}_{4}$ fluxes include only enteric fermentation measured either using the $\mathrm{SF}_{6}$ tracer technique or estimated using a $\mathrm{CH}_{4}$ emission rate $($ see equation 1 in $\mathrm{Soussana}$ et al. (2007)).

\# Measurements in May, August and October.

\$ Measurements were only carried during a 14-17d time span after two fertilization events in January and September. Mean: per fertilizer application. \& Minimum value: cattle-free pasture; maximum value: cattle confined to flux footprint area.

$\S$ Dataset: 3d. Measurements were carried out between 10a.m. and 4p.m. GMT. Maximum: manure perimeter.

** The study investigated fluxes during six comparison periods, covering the months of March - July. Each comparison period lasted between 2 and $28 \mathrm{~d}$.

Abbreviations: ID, identification number for text references; Sites: E, extensive management; I, intensive management; LCRC, Michigan State Univ. Lake City AgBioResearch Center; MUDF4, Massey Univ. № 4 Dairy Farm; Method: AC, automatic chambers; EC, eddy covariance method; EST, estimated (see $\dagger$ ); MC, manual chambers; SF6, SF6 tracer technique; SP, snow profile method; TDL, tunable diode laser method; Sampling frequency or averaging time: CP, mean over comparison period, see notes; DS, dry season mean; DY, daily; GWS, growing season; GZS, grazing season; MN, monthly; MS, multi-site mean; SEM, standard error of monthly or yearly mean; SM, single measurement mean from three chambers; SUM, summer; WIN, winter; WK, weekly; WW, mean over two weeks; YR, year-round or yearly mean; Management: C, cutting; F, fertilization; (F), amount of fertilizer unknown; G, grazing; Notes: MA, manure; MF, mineral fertilizer; PK, synthetic P and K fertilizers; SL, slurry;

This article is protected by copyright. All rights reserved. 
Table $6 \mathrm{~N}_{2} \mathrm{O}$ emission factors for fertilized sites with known amount of applied fertilizer in this study. Cumulative $\mathrm{N}_{2} \mathrm{O}$ emissions for each site were calculated from complete time series after gap-filling via the running median method. For sites with measurements spanning over multiple years, the site mean was calculated as the mean of the respective annual values \pm the standard error of the mean. The site CH-AWS was not included in this table because the amount of applied fertilizer was unknown.

\begin{tabular}{|c|c|c|c|c|c|c|}
\hline Site & Year & $\begin{array}{l}\text { Available data } \\
\text { (days) }\end{array}$ & $\begin{array}{l}\text { Cumulative } \mathrm{N}_{2} \mathrm{O} \text { emissions } \\
\left(\mathrm{kg} \mathrm{N} \mathrm{ha}^{-1}\right)\end{array}$ & $\begin{array}{l}\text { Organic fertilizer } \\
\text { input } \\
\left(\mathrm{kg} \mathrm{N} \mathrm{ha}^{-1}\right)\end{array}$ & $\begin{array}{l}\text { Mineral } \\
\text { fertilizer input } \\
\left(\mathrm{kg} \mathrm{N} \mathrm{ha}^{-1}\right)\end{array}$ & $\begin{array}{l}\text { Emission factor } \\
(\%)\end{array}$ \\
\hline CH-FRU-I & $2010 / 11$ & 35 & 1.02 & 159 & 0 & 0.6 \\
\hline CH-FRU-E & $2010 / 11$ & 35 & 0.83 & 33 & 0 & 2.5 \\
\hline \multirow[t]{3}{*}{ AT-NEU } & 2010 & 215 & 0.19 & 341 & 0 & 0.1 \\
\hline & 2011 & 296 & 0.64 & 341 & 0 & 0.2 \\
\hline & site mean & $256 \pm 41$ & $0.41 \pm 0.22$ & 341 & 0 & $0.1 \pm 0.1$ \\
\hline \multirow[t]{7}{*}{ FR-LAQ-I } & 2008 & 185 & 1.97 & 0 & 214 & 0.9 \\
\hline & 2009 & 103 & 5.28 & 0 & 214 & 2.5 \\
\hline & 2010 & 258 & 1.02 & 0 & 214 & 0.5 \\
\hline & 2011 & 195 & 1.46 & 0 & 214 & 0.7 \\
\hline & 2012 & 198 & 1.21 & 0 & 214 & 0.6 \\
\hline & 2013 & 184 & 0.57 & 0 & 214 & 0.3 \\
\hline & site mean & $187 \pm 20$ & $1.92 \pm 0.70$ & 0 & 214 & $0.9 \pm 0.8$ \\
\hline \multirow[t]{3}{*}{ DE-GAP } & 2012 & 37 & 0.51 & 61 & 0 & 0.8 \\
\hline & 2013 & 55 & 0.57 & 122 & 0 & 0.5 \\
\hline & site mean & $46 \pm 9$ & $0.54 \pm 0.03$ & $92 \pm 31$ & 0 & $0.7 \pm 0.2$ \\
\hline \multirow[t]{4}{*}{ DE-FEN-I } & 2012 & 128 & 2.16 & 312 & 0 & 0.7 \\
\hline & 2013 & 202 & 1.21 & 365 & 0 & 0.3 \\
\hline & 2014 & 296 & 0.76 & 243 & 0 & 0.3 \\
\hline & site mean & $209 \pm 49$ & $1.38 \pm 0.41$ & $307 \pm 35$ & 0 & $0.4 \pm 0.1$ \\
\hline \multirow[t]{4}{*}{ DE-FEN-E } & 2012 & 127 & 0.83 & 61 & 0 & 1.4 \\
\hline & 2013 & 236 & 1.08 & 122 & 0 & 0.9 \\
\hline & 2014 & 296 & 0.76 & 61 & 0 & 1.2 \\
\hline & site mean & $220 \pm 49$ & $0.89 \pm 0.10$ & $81 \pm 20$ & 0 & $1.2 \pm 0.1$ \\
\hline CH-CHA-I1 & $2010 / 11$ & 38 & 5.22 & 190 & 0 & 2.7 \\
\hline CH-CHA-I2 & $2010 / 11$ & 38 & 7.89 & 219 & 0 & 3.6 \\
\hline \multirow[t]{3}{*}{ CH-CHA } & 2012 & 328 & 24.70 & 269 & 17 & 8.6 \\
\hline & 2013 & 360 & 2.55 & 232 & 0 & 1.1 \\
\hline & site mean & $344 \pm 16$ & $13.62 \pm 11.07$ & $251 \pm 19$ & $9 \pm 9$ & $4.9 \pm 2.2$ \\
\hline Mean across sites \pm SEM & & & & & & $1.8 \pm 0.5$ \\
\hline
\end{tabular}

This article is protected by copyright. All rights reserved. 


\section{Figure captions}

Figure 1 Time periods, measurement techniques and number of available days with measurements of $\mathrm{CO}_{2}, \mathrm{~N}_{2} \mathrm{O}$ and $\mathrm{CH}_{4}$ fluxes. The order of sites from top to bottom follows the elevational gradient, with the highest site listed first. Numbers in brackets refer to the number of chamber replicates. See Table 1 for site name abbreviations. AC, automatic chambers; EC, eddy covariance; MC, manual chambers.

Figure 2 Boxplots of measured, non-gapfilled $\mathrm{CO}_{2}, \mathrm{~N}_{2} \mathrm{O}$, and $\mathrm{CH}_{4}$ fluxes. Note the axis break in the $\mathrm{N}_{2} \mathrm{O}$ and $\mathrm{CH}_{4}$ panels. The order of the sites from left to right follows the elevational gradient, starting with the highest elevation site on the left. Colored boxes show the interquartile range $(\mathrm{IQR}=\mathrm{Q} 3-\mathrm{Q} 1)$ of measured data at the respective site, black solid lines inside the colored boxes correspond to the median value. Whiskers extending from the boxes show the range of non-outlier data, defined as Q3 + 1.5 IQR for the upper limit, and as Q1 - 1.5 IQR for the lower limit. Data points beyond the whiskers are considered outliers and plotted as individual points. Colors show the season of the year: spring (March - May, green), summer (June - August, red), autumn (September - November, orange) and winter (December - February, blue). See Table 1 for site name abbreviations.

Figure 3 Hexbin plots of measured, non-gapfilled $\mathrm{N}_{2} \mathrm{O}$ fluxes in twelve combined classes of soil temperature and water-filled pore space. Prior to analysis, daily average values of all three variables at each site were converted to an index in the range 0 to $100 \%$, based on the cumulative empirical probability density function (cePDF) of each variable at each site, i.e. the index corresponds with the percentile value of the original measurements in relation to the site-specific cePDF. Colored (red-to-blue gradient) hexbins show the percentile $\mathrm{N}_{2} \mathrm{O}$ flux in the respective combined class, while white hexbins show the lack of measurements. (a) Aggregated $\mathrm{N}_{2} \mathrm{O}$ flux

This article is protected by copyright. All rights reserved. 
percentile values for each site, showing the median of each percentile flux within each aggregation unit. Black dots in hexbins indicate that the respective median percentile flux corresponds to $\mathrm{N}_{2} \mathrm{O}$ uptake, while the absence of black dots indicates $\mathrm{N}_{2} \mathrm{O}$ emission. The order of sites from left to right and from top to bottom follows the elevational gradient, with results for the highest site shown at the top left. (b) Aggregated $\mathrm{N}_{2} \mathrm{O}$ flux percentile values across all sites, calculated as the median of site-level hexbin values in (a), when data from at least two sites were available for a specific combined class. Additional information on percentile distributions at each site is given in Table 2. See Table 1 for site name abbreviations.

Figure 4 Hexbin plots of measured, non-gapfilled $\mathrm{CH}_{4}$ fluxes in twelve combined classes of soil temperature and water-filled pore space. Prior to analysis, daily average values of all three variables at each site were converted to an index in the range 0 to $100 \%$, based on the cumulative empirical probability density function (cePDF) of each variable at each site, i.e. the index corresponds with the percentile value of the original measurements in relation to the site-specific cePDF. Colored (red-to-blue gradient) hexbins show the percentile $\mathrm{CH}_{4}$ flux in the respective combined class, while white hexbins show the lack of measurements. The site FR-LAQ-I was not included for this analysis due to the presence of cattle in the flux footprint. (a) Aggregated $\mathrm{CH}_{4}$ flux percentile values for each site, showing the median of each percentile flux within each aggregation unit. Black dots in hexbins indicate that the respective median percentile flux corresponds to $\mathrm{CH}_{4}$ uptake, while the absence of black dots indicates $\mathrm{CH}_{4}$ emission. The order of sites from left to right and from top to bottom follows the elevational gradient, with results for the highest site shown at the top left. (b) Aggregated $\mathrm{CH}_{4}$ flux percentile values across all sites, calculated as the median of site-level hexbin values in (a), when data from at least two sites were

This article is protected by copyright. All rights reserved. 
available for a specific combined class. Additional information on percentile distributions at each site is given in Table 2 . See Table 1 for site name abbreviations.

Figure 5 Linear regression analysis of average percentile fluxes across sites in classes of (a) soil temperature and (b) water-filled pore space, based on the respective hexbin classes shown in Figure $3 b$ for $\mathrm{N}_{2} \mathrm{O}$ fluxes and Figure $4 \mathrm{~b}$ for $\mathrm{CH}_{4}$ fluxes. The shaded area refers to the standard deviation of average percentile fluxes in the respective soil temperature or water-filled pore space class. Percentile distributions for each site along with percentile ranges across all sites in this analysis are given in Table 2.

Figure 6 Explained variance $\left(\mathrm{r}^{2}\right)$ from a multiple linear regression analysis of measured, nongapfilled, log-transformed $\mathrm{N}_{2} \mathrm{O}$ daily average fluxes in dependence of soil temperature (TS) and water-filled pore space (WFPS), performed in a moving time window of 35 days. Results were calculated if a minimum of 13 days of data were available within a specific time window. Blue markers denote days with snow cover, vertical lines show management events (dotted: cutting, dashed: fertilization), grey horizontal bars show the regression time window for the respective $\mathrm{r}^{2}$. Red dots mark time periods where the regression was significant at $P<0.05$. See Table 1 for site name abbreviations.

Figure 7 Explained variance $\left(\mathrm{r}^{2}\right)$ from a multiple linear regression analysis of measured, nongapfilled, log-transformed $\mathrm{CH}_{4}$ daily average fluxes in dependence of soil temperature (TS) and water-filled pore space (WFPS), performed in a moving time window of 35 days. Results were calculated if a minimum of 13 days of data were available within a specific time window. Blue markers denote days with snow cover, vertical lines show management events (dotted: cutting, dashed: fertilization), grey horizontal bars show the regression time window for the respective $\mathrm{r}^{2}$. Red dots mark time periods where the regression was significant at $\mathrm{P}<0.05$. Note that no $\mathrm{CH}_{4}$

This article is protected by copyright. All rights reserved. 
measurements were available for FR-LAQ-E and that cattle were present in the flux footprint for $\mathrm{CH}_{4}$ measurements at FR-LAQ-I. See Table 1 for site name abbreviations.

Figure 8 Measured, non-gapfilled $\mathrm{N}_{2} \mathrm{O}$ fluxes at three sites during each fertilizer application of liquid slurry. Left panel: daily average fluxes for seven pre-fertilization days (-7 to -1$)$, the day of application (0) and seven post-fertilization days (1 to 7), expressed in $\mu \mathrm{g} \mathrm{m}^{-2} \mathrm{~h}^{-1}$. Right panel: absolute ratio of measured fluxes to the 7-day pre-fertilization average for each management event. See Table 1 for site name abbreviations.

Figure 9 Measured, non-gapfilled $\mathrm{CH}_{4}$ fluxes at three sites during each fertilizer application of liquid slurry. Left panel: daily average fluxes for seven pre-fertilization days (-7 to -1$)$, the day of application (0) and seven post-fertilization days (1 to 7), expressed in $\mu \mathrm{g} \mathrm{m}^{-2} \mathrm{~h}^{-1}$. Right panel: absolute ratio of measured fluxes to the 7-day pre-fertilization average for each management event. See Table 1 for site name abbreviations.

This article is protected by copyright. All rights reserved. 


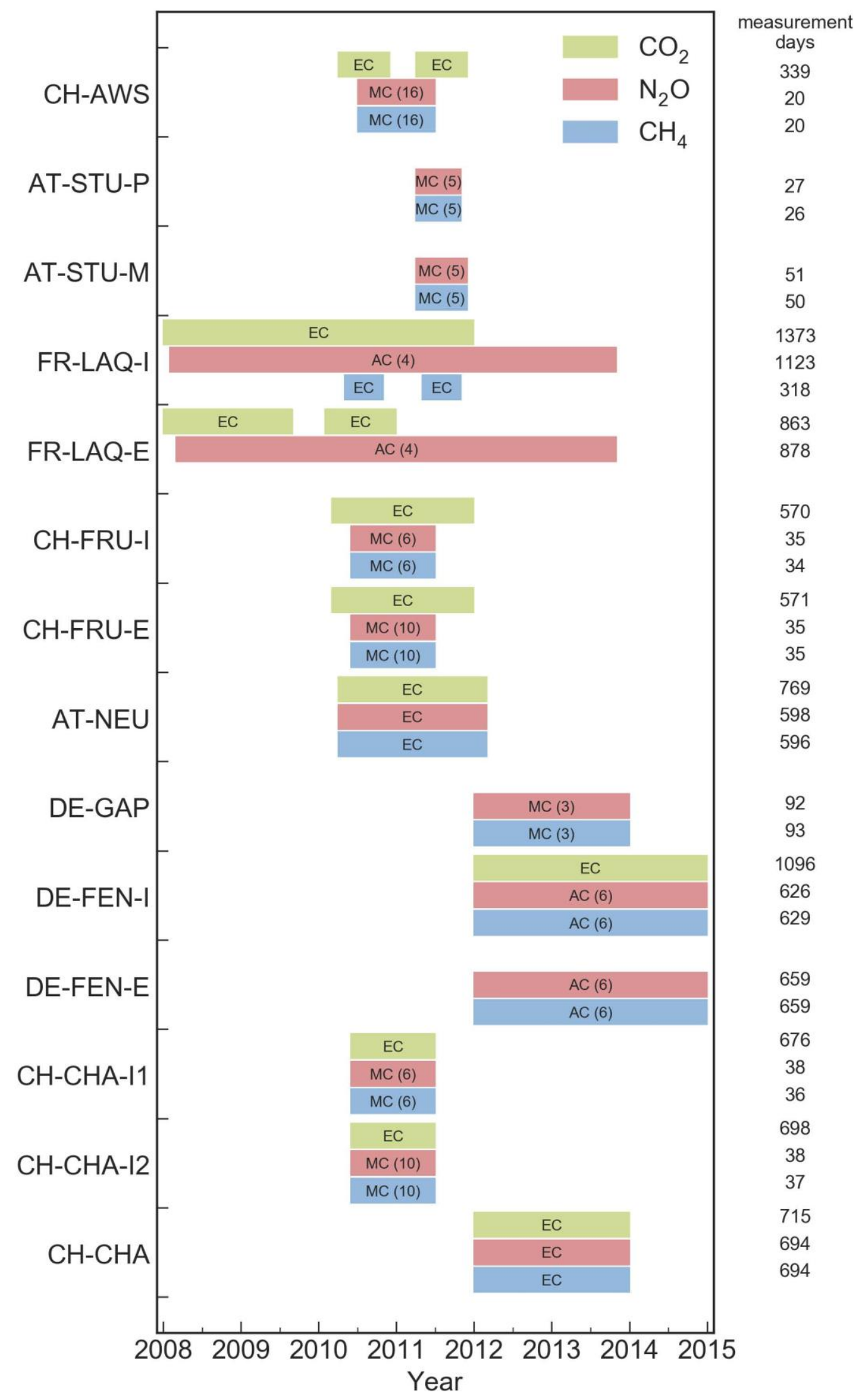

This article is protected by copyright. All rights reserved. 

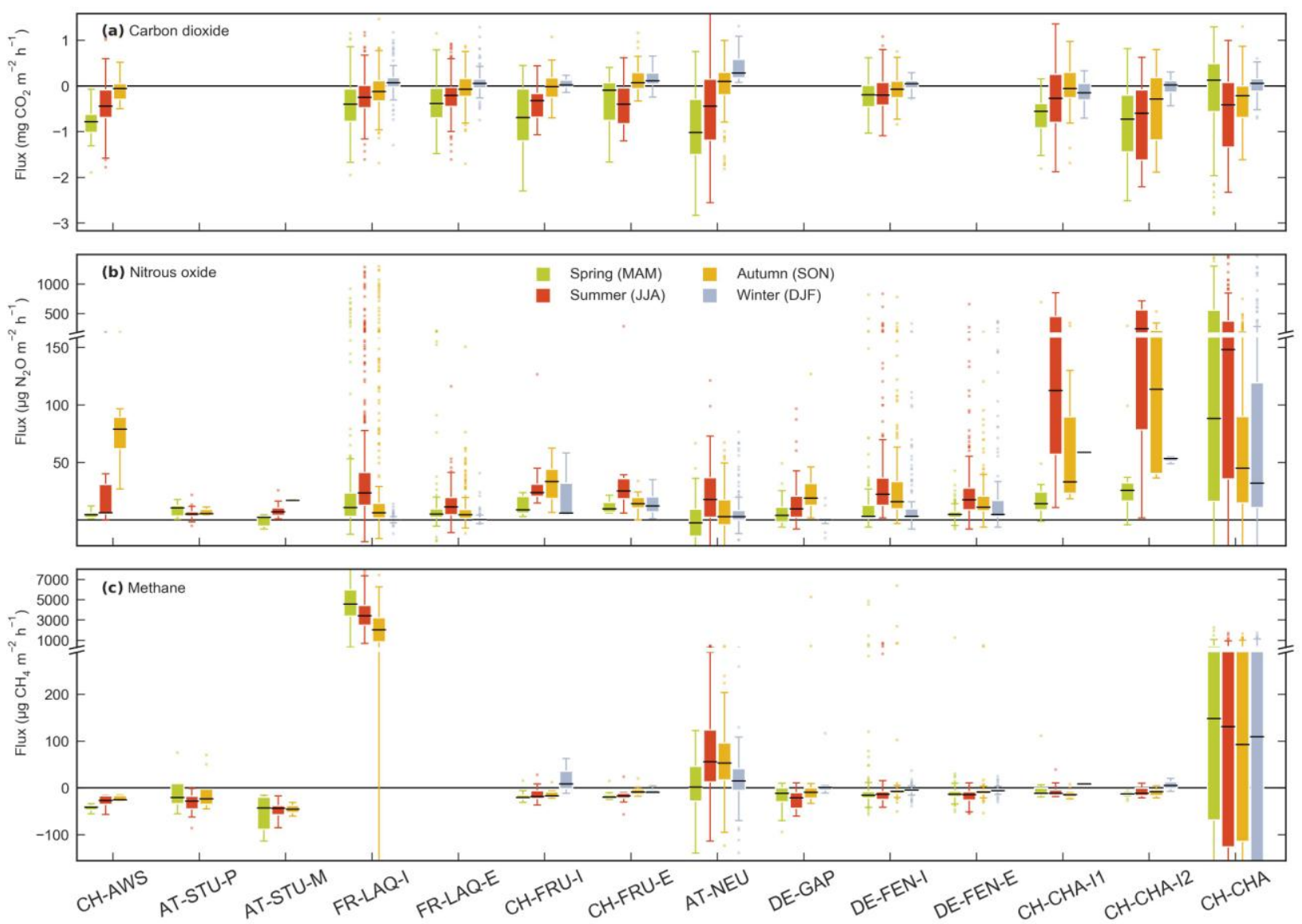

This article is protected by copyright. All rights reserved. 
(a)

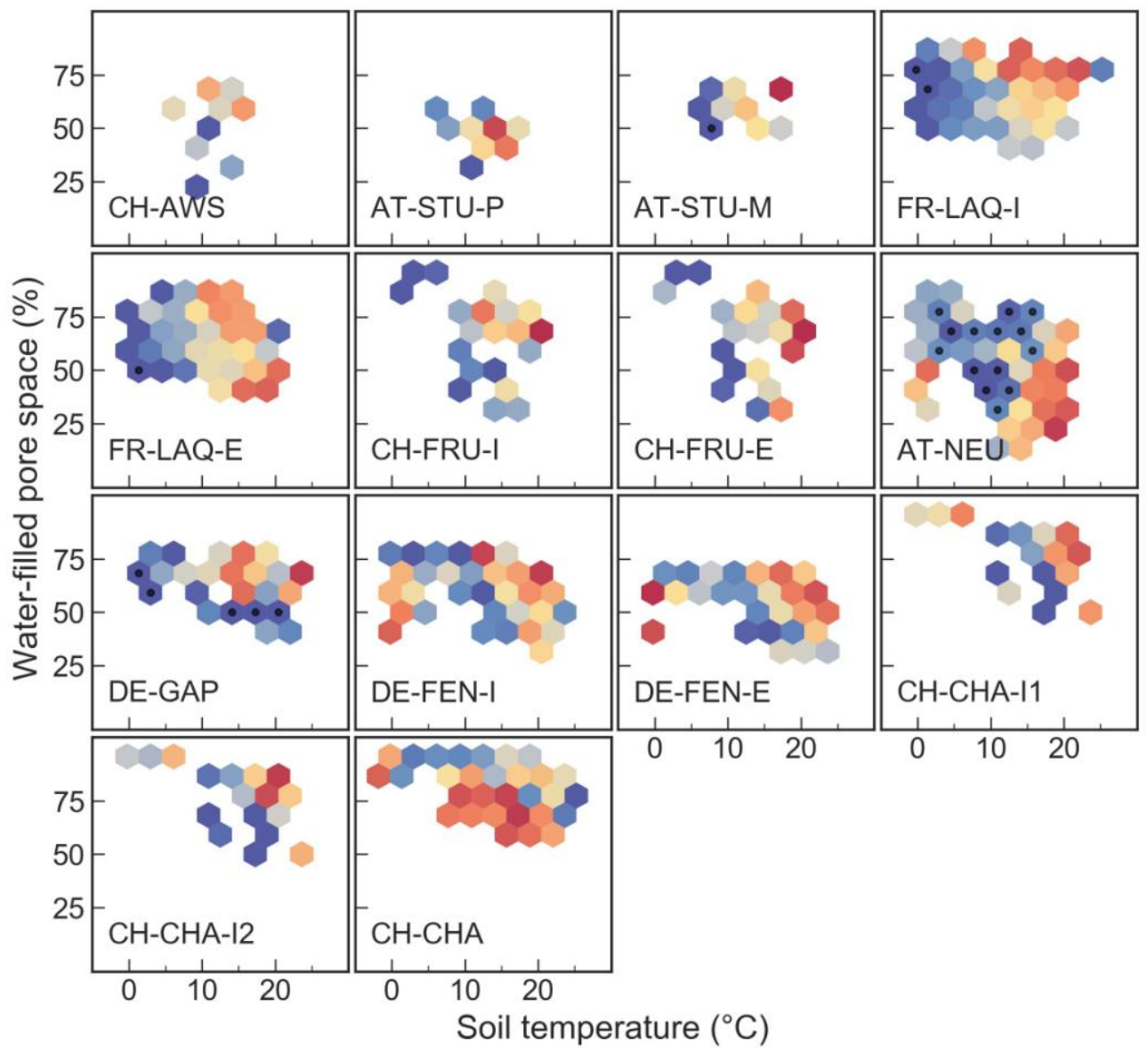

(b)

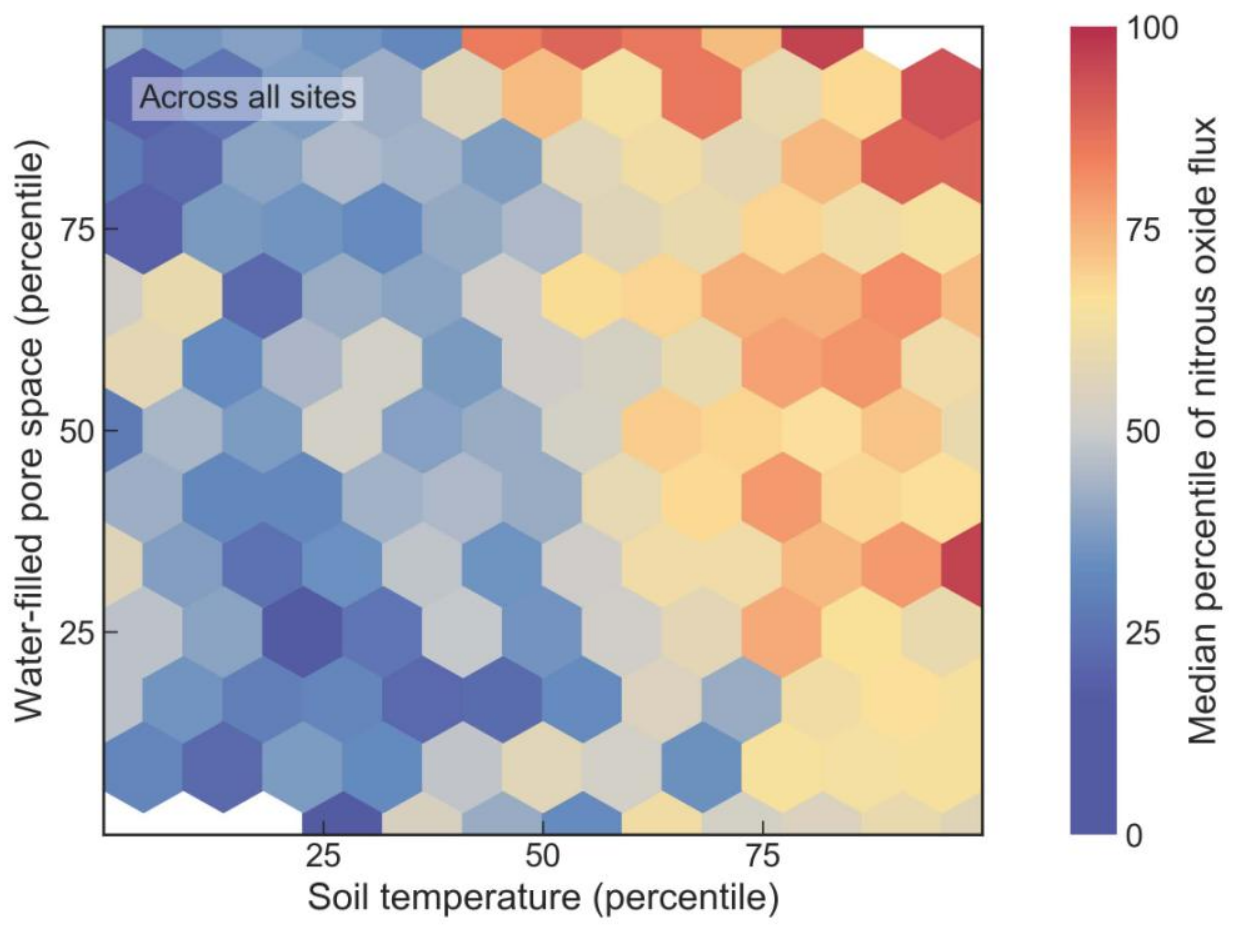

This article is protected by copyright. All rights reserved. 
(a)

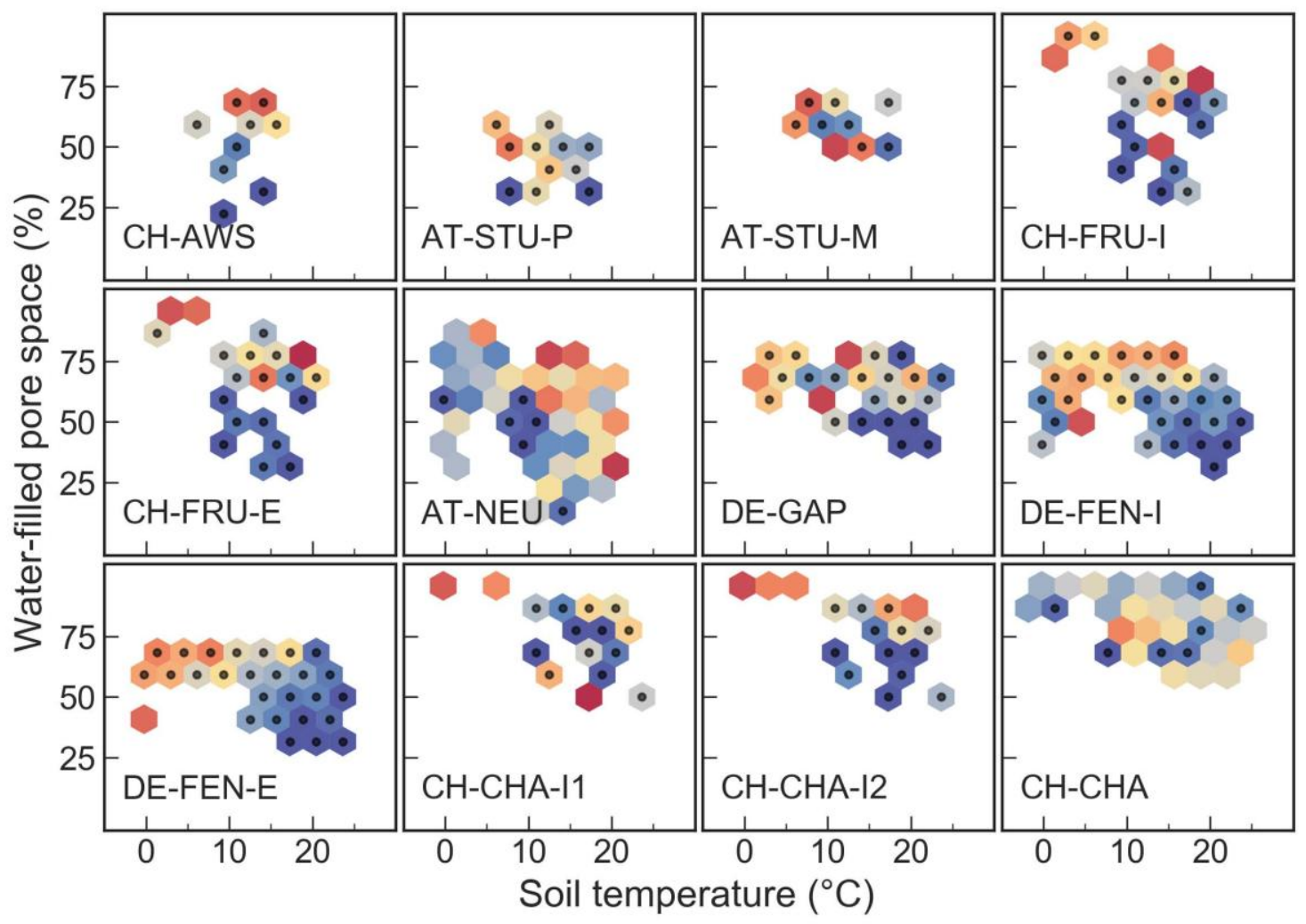

(b)

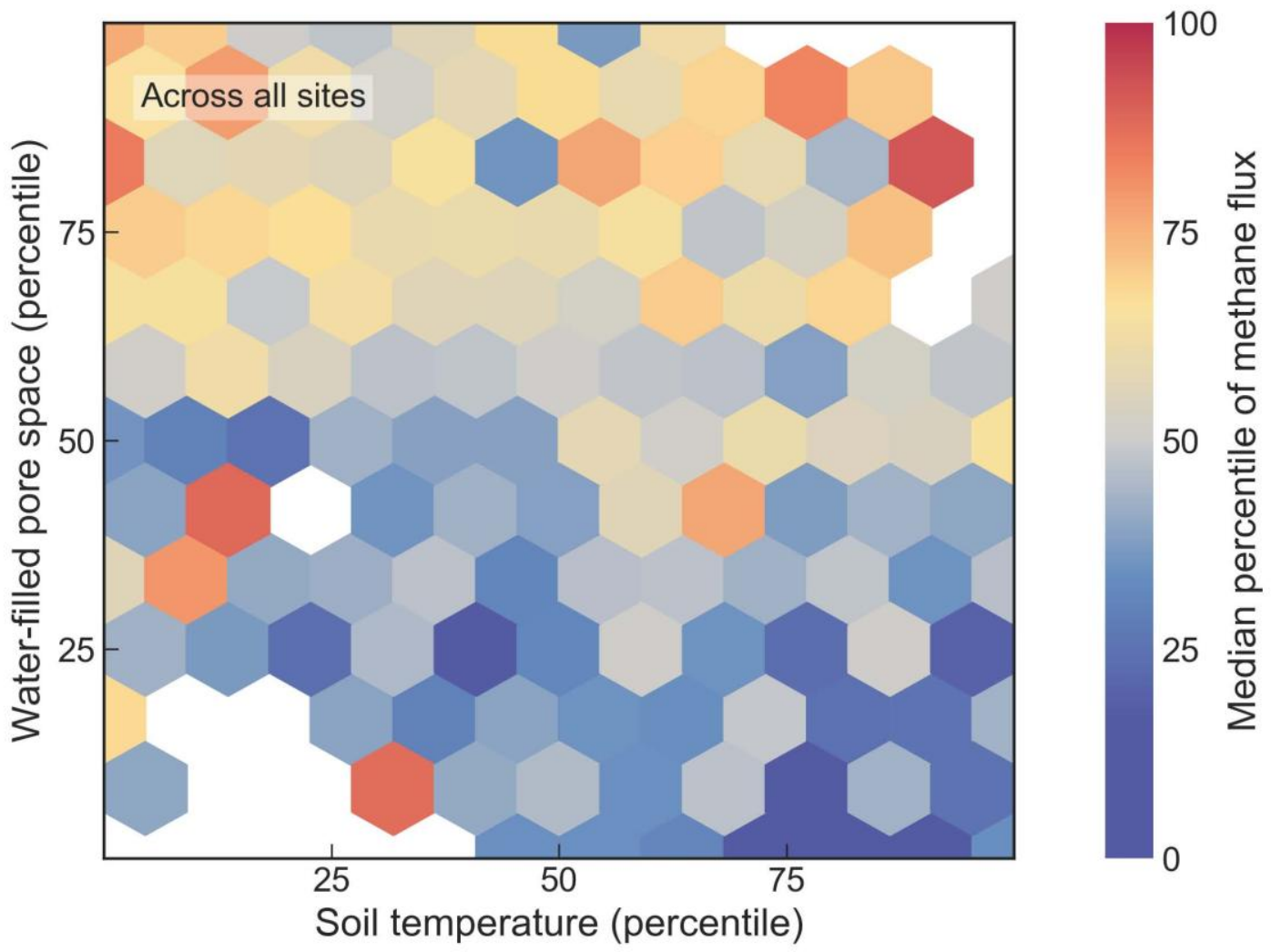

This article is protected by copyright. All rights reserved. 

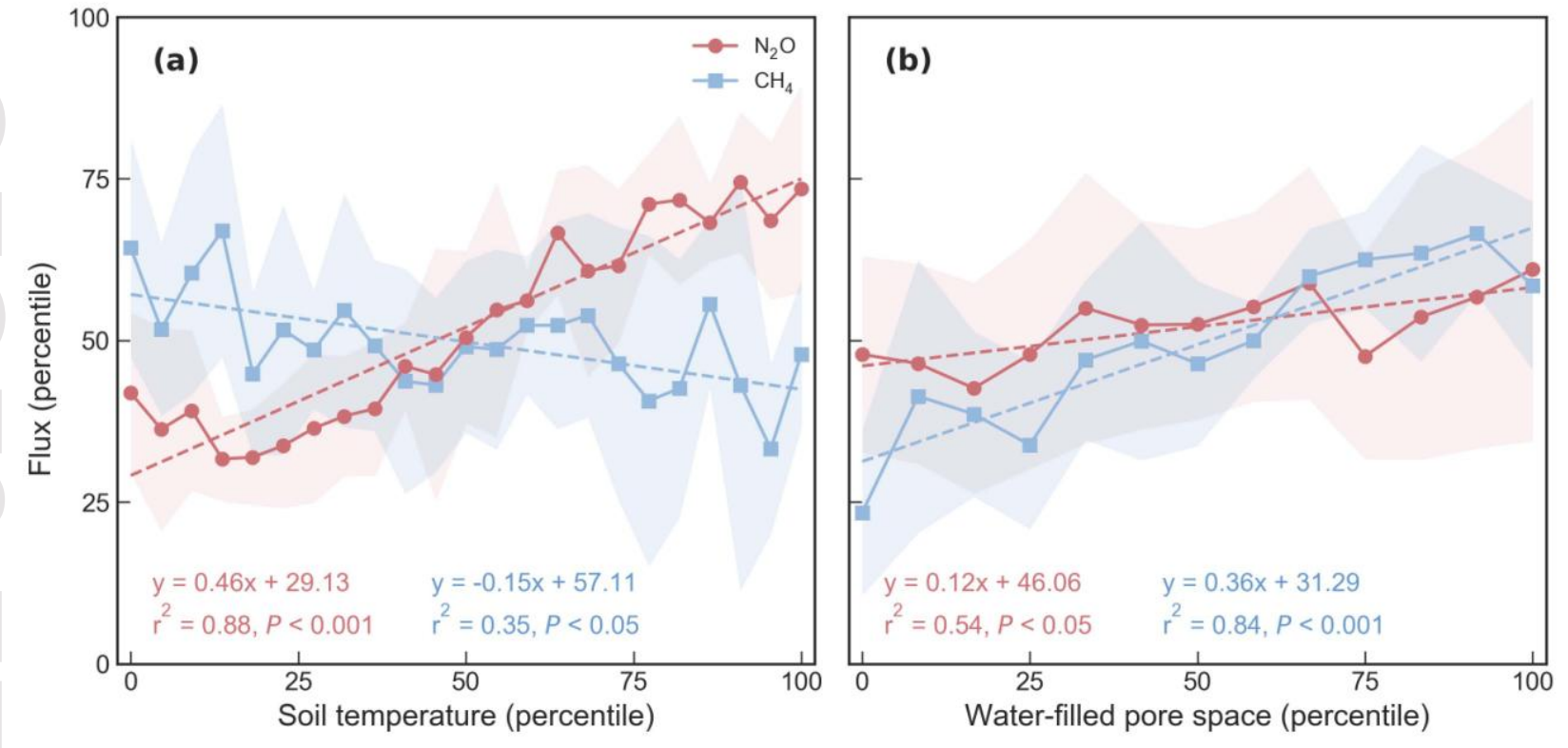

This article is protected by copyright. All rights reserved. 
$\mathrm{N}_{2} \mathrm{O}$ Flux
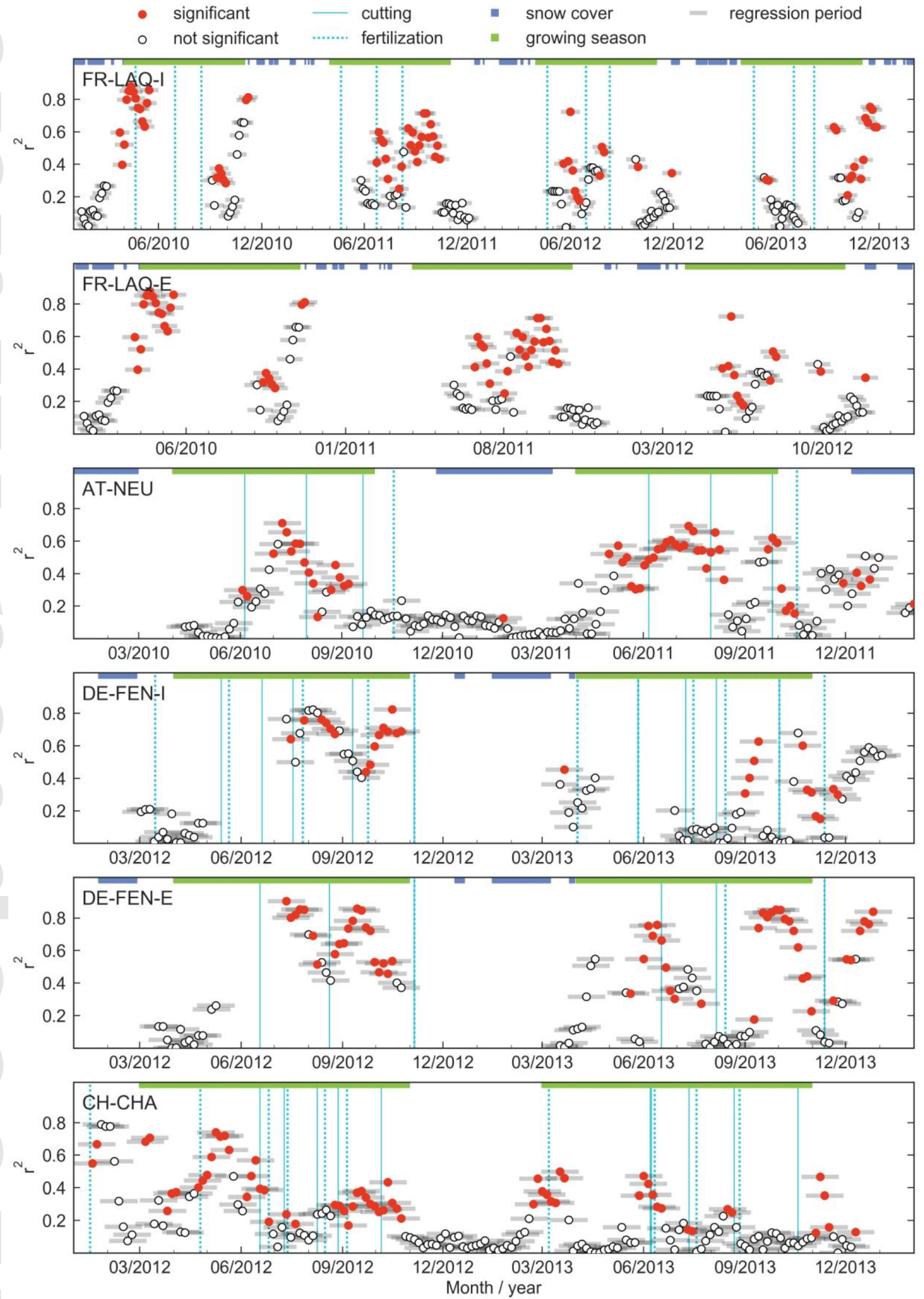

This article is protected by copyright. All rights reserved. 

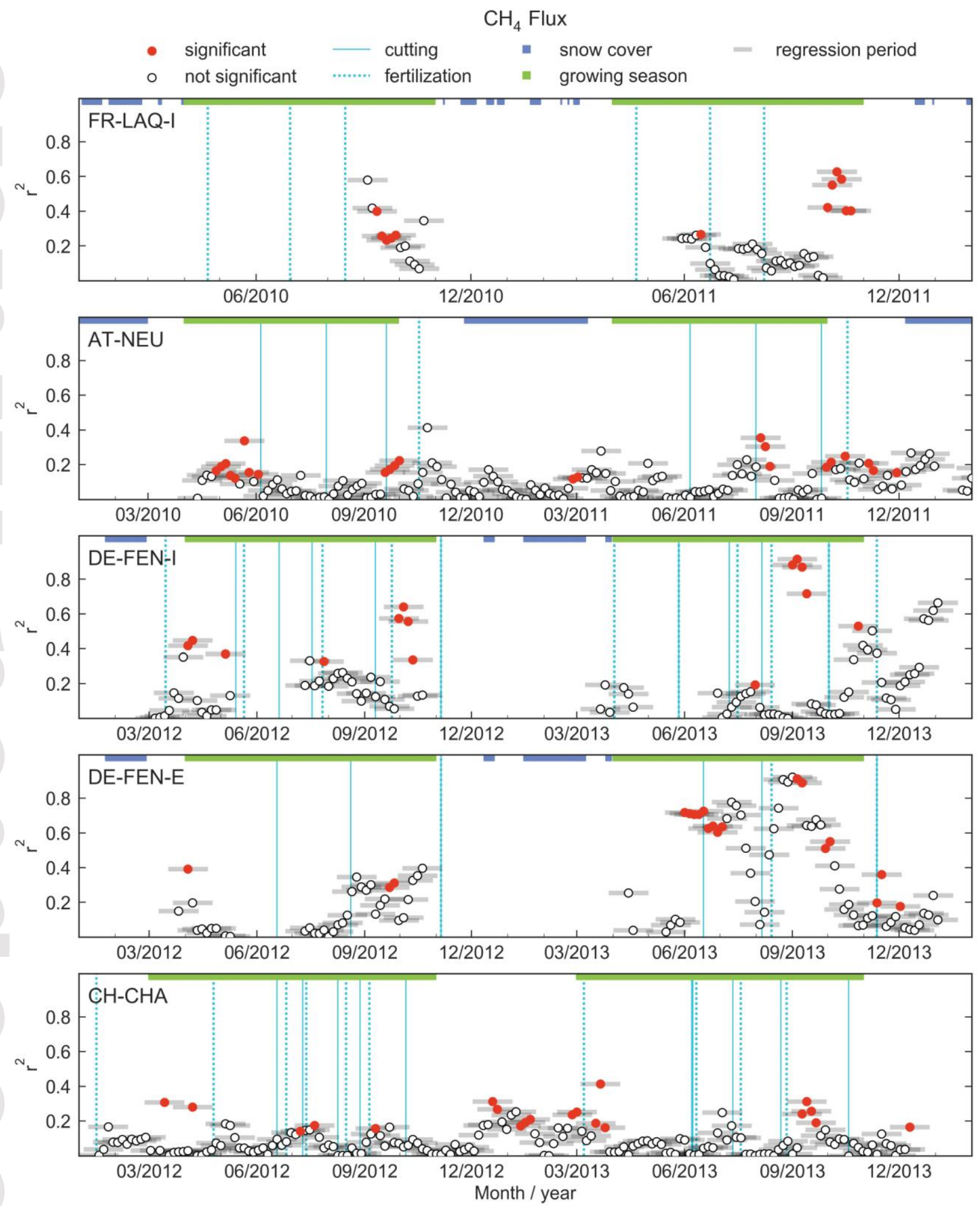

This article is protected by copyright. All rights reserved. 


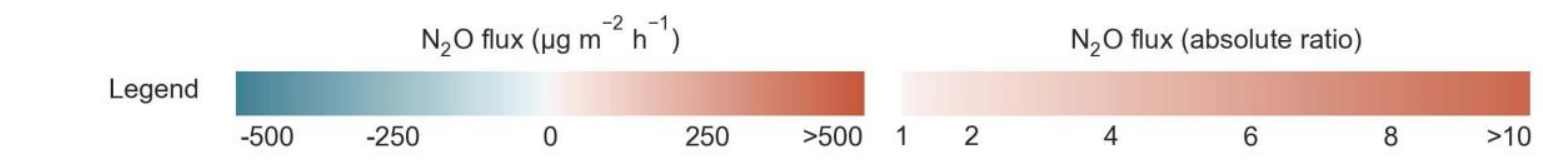

\section{$\mathrm{CH}-\mathrm{CHA}$}

13 Jul 2012

16 Aug 2012

05 Sep 2012

11 Jun 2013

19 Jul 2013

27 Aug 2013

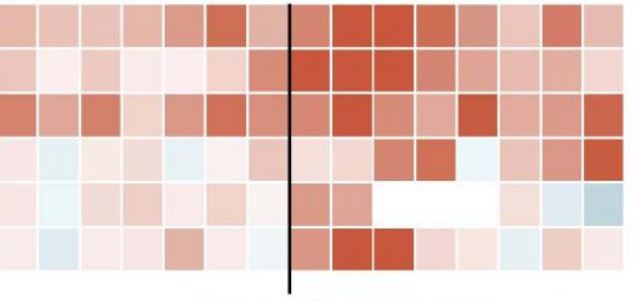

before after fertilization

DE-FEN-I

15 Mar 2012

27 Jul 2012

24 Sep 2012

16 Jul 2013

14 Aug 2013

02 Oct 2013

12 Nov 2013

19 Mar 2014

28 May 2014

15 Jul 2014

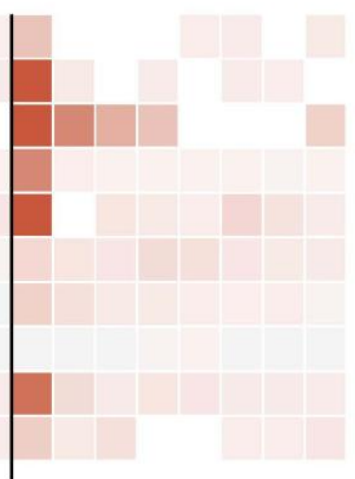

DE-FEN-E

14 Aug 2013

12 Nov 2013

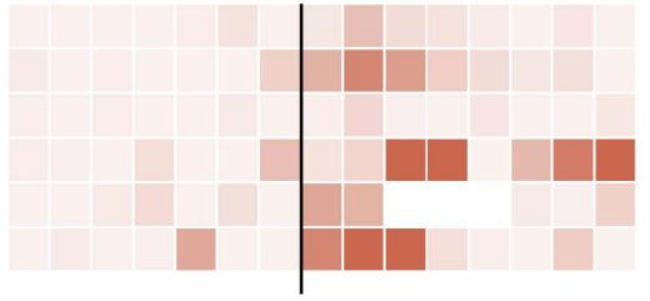

before after fertilization
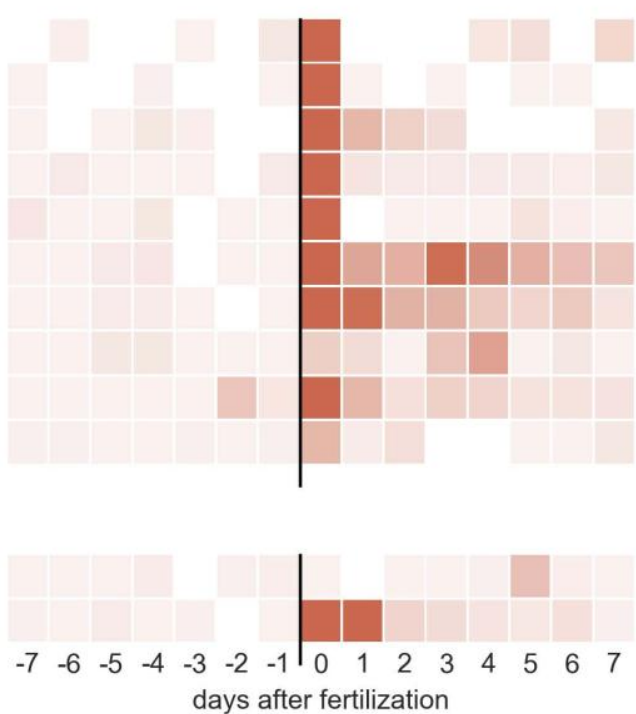

This article is protected by copyright. All rights reserved. 


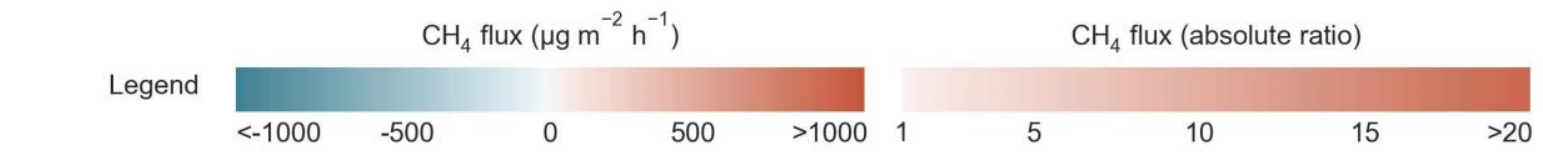

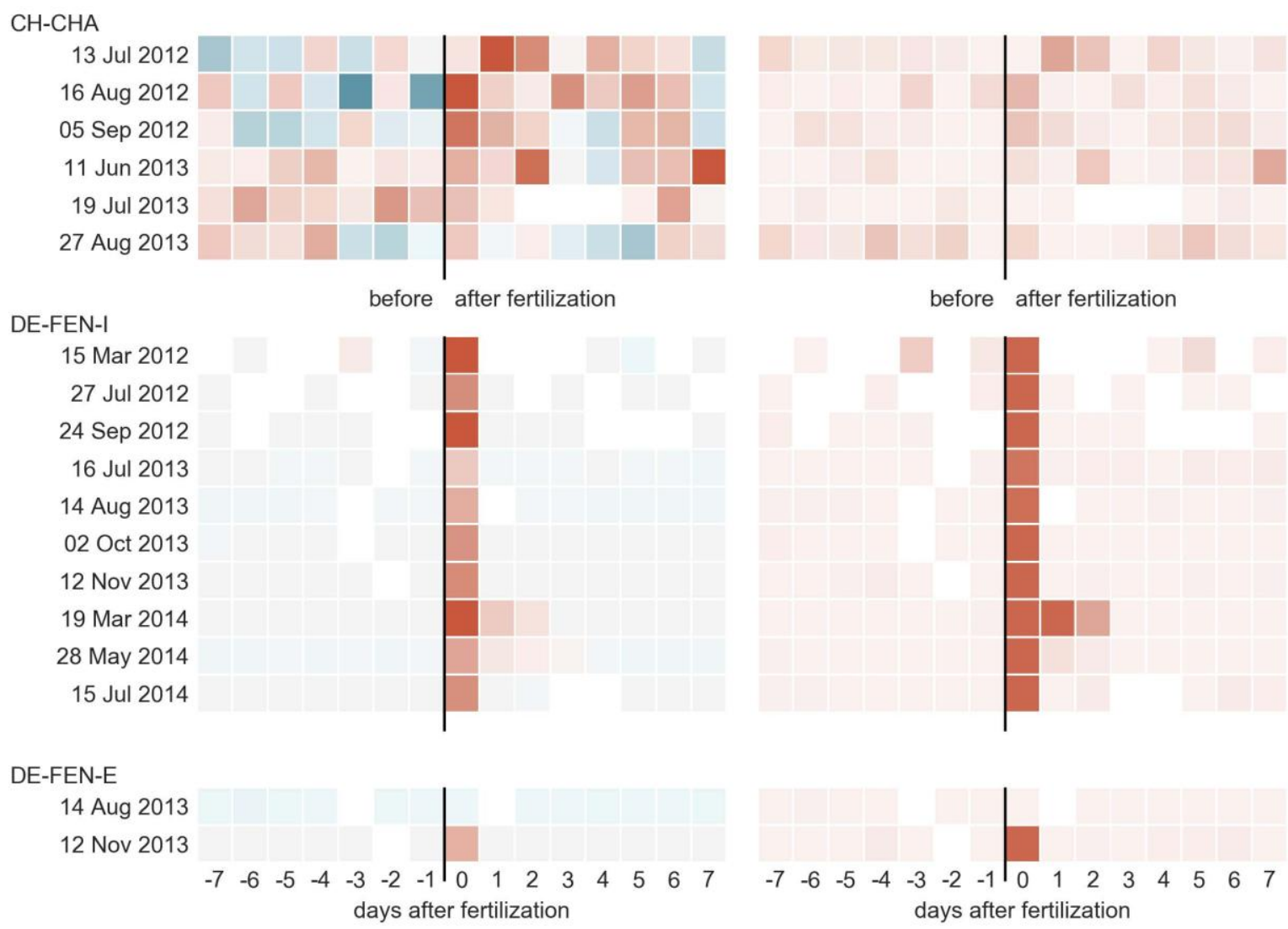

This article is protected by copyright. All rights reserved. 